\title{
A conformationally-restricted aza-BODIPY platform for stimulus-responsive probes with enhanced photoacoustic properties
}

\author{
Effie Y. Zhou ${ }^{\dagger}$, Hailey J. Knox ${ }^{\dagger}$, Chang Liu ${ }^{\ddagger}$, Weili Zhao ${ }^{\ddagger \S}$, Jefferson Chan ${ }^{\dagger *}$ \\ $\dagger^{\dagger}$ Department of Chemistry and Beckman Institute for Advanced Science and Technology, \\ University of Illinois at Urbana-Champaign, 600 S. Mathews, Urbana, Illinois 61801, USA \\ ‡School of Pharmacy, Institutes of Integrative Medicine, Fudan University, Shanghai, 201203, \\ P.R. China; ${ }^{\S}$ Key Laboratory for Special Functional Materials of the Ministry of Education, \\ Henan University, Kaifeng, 475004, P.R. China \\ Correspondence should be addressed to J.C. (jeffchan@illinois.edu).
}

\section{Table of Contents}

1. Materials

2. Instrumentation and data processing

3. Fluorescence quantum yields

4. Region of interest selection and validation

5. Synthetic methods

6. Supplementary figures and tables

Materials. Copper(II) chloride dihydrate and triethylamine were purchased from Acros Organics. Allyl bromide and cyclohexane were purchased from Alfa Aesar. 4-Methoxyphenylboronic acid was purchased from Ark Pharm. NADPH tetrasodium salt was purchased from CalBioChem. Deuterated solvents were purchased from Cambridge Isotope Laboratories. 6-Hydroxy-1-tetralone was purchased from Combi-Blocks. $1 \times$ PBS (without calcium or magnesium) was purchased from Corning. Ammonium chloride, dichloromethane, dichloroethane, diethyl ether, ethyl acetate, ethylene glycol, glacial acetic acid, hexanes, tetrahydrofuran, and potassium phosphate monobasic were purchased from Fisher Scientific. Agarose LE was purchased from Gold BioChem. TLC plates, and silica and alumina for flash chromatography, were purchased from Machery-Nagel. Chloroform, methanol (anhydrous) and sodium hydroxide were purchased from Macron Fine Chemicals. Ethyl isocyanoacetate was purchased from Matrix Scientific. Fluorinated ethylene propylene (FEP) tubing (wall thickness 0.01", inner diameters 0.08 " and 0.12") was purchased 
from McMaster-Carr. 1-Tetralone, 2,6-dichlorophenol, 2-bromo-2-methylpropanamide, 4'aminoacetophenone, 4'-methoxyacetophenone, 6-methoxy-1-tetralone, acetic anhydride, celite, di-tert-butyl-dicarbonate, bromoethane, ethyl iodide, methyl iodide, $\mathrm{N}$-iodosuccinimide, potassium carbonate, potassium hydroxide, p-toluenesulfonic acid hydrate, sodium azide, sodium bicarbonate, sodium borohydride, sodium nitrite, sodium sulfate, sodium thiosulfate, TEMPO, tetrakis(triphenylphosphine)palladium(0), and triflic acid were purchased from Oakwood Chemical. 1,4-Dioxane, acetyl chloride, boron trifluoride diethyl etherate, bromine, DBU, $N, N$ dimethylacetamide, rat liver microsomes, sodium hydride, styrene, tert-butyl nitrite, and all additional anhydrous solvents were purchased from Sigma Aldrich. Hydrochloric acid and potassium phosphate dibasic were purchased from VWR.

Instrumentation and data processing. ${ }^{1} \mathrm{H},{ }^{13} \mathrm{C},{ }^{11} \mathrm{~B}$, and ${ }^{19} \mathrm{~F}$ NMRs were acquired on a Varian 400, Varian 500, or Carver B500 spectrometer. Spectra were visualized and analyzed using MestReNova (version 12.0.3). Absorbance spectra were acquired with an Agilent Cary 60 UV-Vis spectrophotometer. Fluorescence traces were acquired with QuantaMaster-400 scanning spectrofluorometer with micro fluorescence quartz cuvettes (Science Outlet). A Nexus 128 Photoacoustic Tomographer (Endra Life Sciences) was used for acquiring photoacoustic data and images. All PA spectra were acquired using continuous rotation mode with a 3 second rotation time. All other images were acquired using continuous rotation mode with a 6 second rotation time. PA data were analyzed using Horos (version 2.2.0) imaging software. No background subtraction was used for any analysis in this work. Statistical analysis was conducted using GraphPad Prism8.

Fluorescence quantum yields. Relative fluorescence quantum yields were measured for all compounds in this study. Main text compounds 1-6 (including red-CRaB-HyP), red-HyP-1, rNOD, and CRaB-rNOD were dissolved in $\mathrm{CHCl}_{3}$ and assessed relative to ICG in DMSO $\left(\lambda_{\mathrm{ex}}=\right.$ $740 \mathrm{~nm}, \lambda_{\mathrm{em}}=750 \mathrm{~nm}-1000 \mathrm{~nm}$ ). t-OMe-APC, and CRaB-t-OMe-APC were dissolved in $\mathrm{CHCl}_{3}$ spiked with $\mathrm{Et}_{3} \mathrm{~N}$ and assessed relative to ICG in DMSO ( $\left.\lambda_{\mathrm{ex}}=740 \mathrm{~nm}, \lambda_{\mathrm{em}}=750 \mathrm{~nm}-1000 \mathrm{~nm}\right)$. rNOD was dissolved in $\mathrm{CHCl}_{3}$ and assessed relative to ICG in DMSO $\left(\lambda_{\mathrm{ex}}=710 \mathrm{~nm}, \lambda_{\mathrm{em}}=720\right.$ $\mathrm{nm}-1000 \mathrm{~nm}$ ). HyP-1, CRaB-HyP-1, OMe-APC, CRaB-OMe-APC, photoNOD-1 and CRaBphotoNOD were dissolved in $\mathrm{CHCl}_{3}$ and assessed relative to a symmetrical methoxy-substituted 
aza-BODIPY (used by Zhao and Carreira, Chem. Euro. J. 2006. 12:7254-7263) in $\mathrm{CHCl}_{3}\left(\lambda_{\text {ex }}=\right.$ $\left.650 \mathrm{~nm}, \lambda_{\mathrm{em}}=660 \mathrm{~nm}-1000 \mathrm{~nm}\right)$.

Region of interest selection and validation. Upon collection of in vivo PA images, regions of interest (ROIs) were selected in order to quantify HyP-1 or CRaB-HyP turn-on under hypoxic conditions. ROIs were characterized by the presence of bright pools of dye, which could be detected as regions that demonstrated substantially higher PA intensity than the surrounding tissue. These regions were identified by visualizing the images with various lower-bound intensity cutoffs (Figure S7, A. $0-6000$, B. $1000-6000$, and C. $4000-6000$ units) to limit the visualization of the blood and surrounding tissue. ROIs were further validated by confirming that under hypoxic conditions, ratiometric turn-on was identified only in the presence of the pooled dye (Figure S8, Table S5). It is worth noting that these visualizations were generated using the Horos software and have no impact upon the measured PA intensities.

\section{Synthetic methods.}

Scheme S1. Preparation of bottom-fused pyrroles $\boldsymbol{b}$ and $\boldsymbol{e}$.
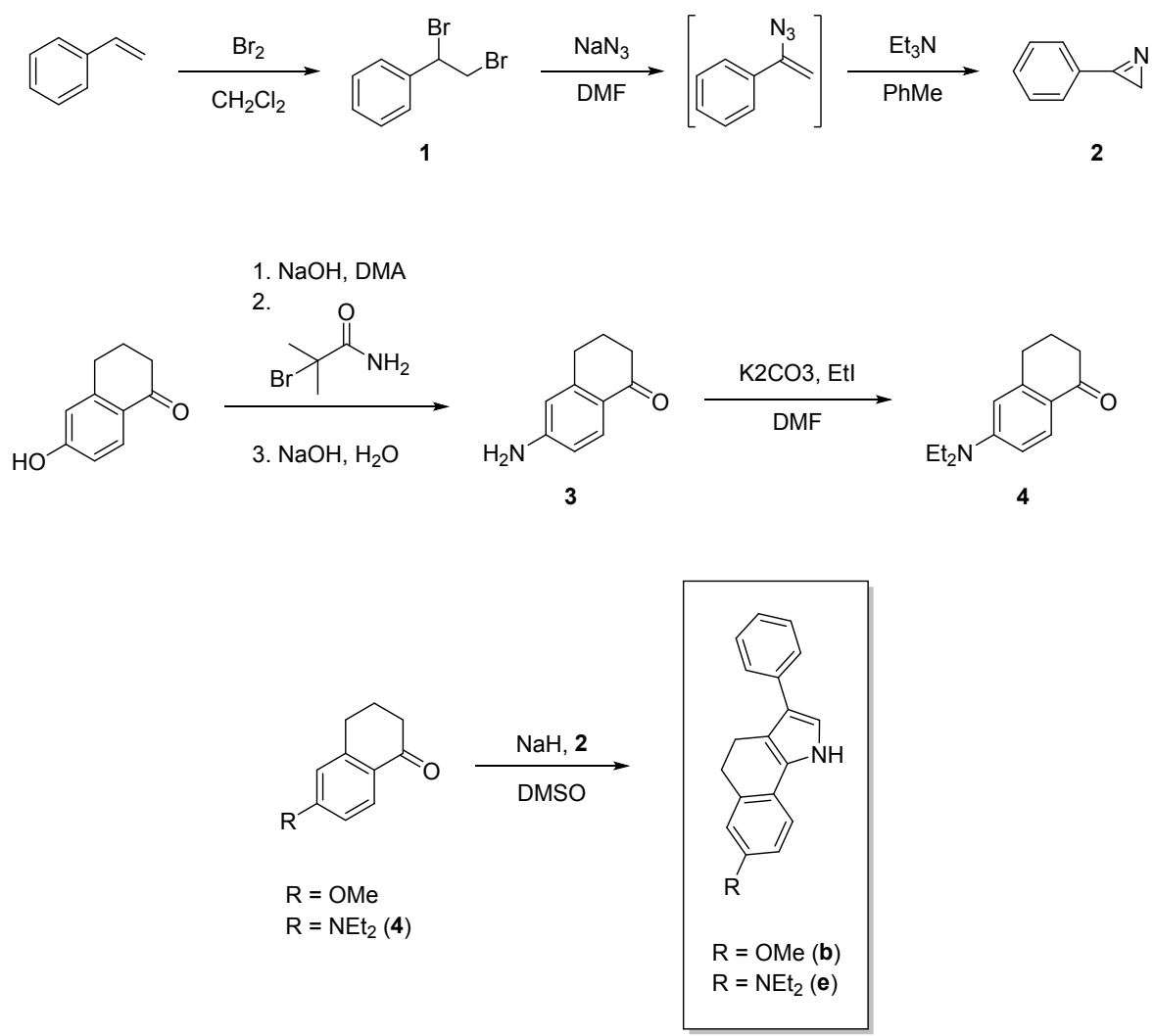
(1,2-dibromoethyl)benzene (1). To a $250 \mathrm{~mL}$ RBF were added styrene (22.9 mL, $200 \mathrm{mmol}, 1$ eq.) and dichloromethane $(400 \mathrm{~mL})$. The solution was cooled to $0{ }^{\circ} \mathrm{C}$, and bromine $(12.3 \mathrm{~mL}, 240$ mmol, 1.2 eq.) was added dropwise via addition funnel. The red reaction mixture was raised to room temperature and stirred for one hour. Upon completion by TLC, the reaction mixture was cooled to $0{ }^{\circ} \mathrm{C}$, diluted with water, and quenched with slow addition of saturated sodium thiosulfate until complete decolorization was noted. The organic layer was dried with sodium sulfate, concentrated to a white powder (51.0 g, $193 \mathrm{mmol}, 97 \%$ yield) and used without purification.

3-phenyl-2H-azirine (2). To a $100 \mathrm{~mL}$ RBF were added 1 (2.64 g, $10 \mathrm{mmol}, 1.0$ eq.), DMF (anhydrous) (40 mL), and sodium azide (1.95 g, $30 \mathrm{mmol}, 3.0$ eq.). The reaction mixture was stirred vigorously for $5 \mathrm{~h}$. Upon complete consumption of 1 by TLC (hexanes), the reaction mixture was diluted in water and extracted with diethyl ether. The organic layers were washed with brine, concentrated to an oil, and transferred to a preheated RBF containing toluene $(15 \mathrm{~mL})$ and triethylamine $(2.0 \mathrm{~mL})$. The reaction mixture was heated at $110{ }^{\circ} \mathrm{C}$ for $40 \mathrm{~min}$, then cooled rapidly in an ice bath. The crude reaction mixture was loaded directly onto a large pre-packed silica column (5\% ethyl acetate/hexanes) and purified with 5\% ethyl acetate/hexanes to yield a pale yellow oil (482 mg, $4.1 \mathrm{mmol}, 41 \%$ yield). ${ }^{1} \mathrm{H}$ NMR (500 MHz, $\left.\mathrm{CDCl}_{3}\right) \delta 7.98-7.88(\mathrm{~m}$, 2H), $7.68-7.52$ (m, 3H), 1.79 (s, 3H). ${ }^{13} \mathrm{C}$ NMR (126 MHz, $\left.\mathrm{CDCl}_{3}\right) \delta$ 165.91, 133.05, 129.71, $129.18,125.61,19.82$.

6-amino-1-tetralone (3). To a $50 \mathrm{~mL} \mathrm{RBF}$ were added 6-hydroxy-1-tetralone (811 mg, 5.00 mmol, 1.0 eq.), sodium hydroxide (600 mg, $15.0 \mathrm{mmol}, 3.0$ eq.) and $N, N$-dimethylacetamide (7.15 $\mathrm{mL})$. The reaction mixture was stirred for $1.5 \mathrm{~h}$ at room temperature. Then 2-bromo-2methylpropanamide ( $2.49 \mathrm{~g}, 15.0 \mathrm{mmol}, 3.0$ eq.) was added and the reaction mixture was stirred at room temperature overnight. Upon consumption of starting material by TLC (50\% ethyl acetate/hexanes), indicating complete alkylation, additional $\mathrm{NaOH}(1.80 \mathrm{~g}, 45.0 \mathrm{mmol}, 9.0$ eq.) was added and the reaction mixture was heated to $60{ }^{\circ} \mathrm{C}$ for $1 \mathrm{~h}$. Upon completion of the rearrangement reaction by TLC, the reaction mixture was diluted with water $(7 \mathrm{~mL})$ and refluxed for $1 \mathrm{~h}$. Upon completion of the hydrolysis by TLC, the reaction mixture was diluted with a further $14 \mathrm{~mL}$ water and cooled on an ice bath until product precipitation was noted. The solids were isolated by vacuum filtration, washed with water, and dried. The product was purified by trituration in a 1:1 mixture of hexanes and dichloromethane to yield a beige solid (556 mg, $3.45 \mathrm{mmol}, 69 \%$ 
yield). ${ }^{1} \mathrm{H}$ NMR $\left(500 \mathrm{MHz}, \mathrm{CDCl}_{3}\right) \delta 7.88(\mathrm{~d}, J=8.5 \mathrm{~Hz}, 1 \mathrm{H}), 6.53(\mathrm{dd}, J=8.5,2.3 \mathrm{~Hz}, 1 \mathrm{H}), 6.44$ $-6.39(\mathrm{~m}, 1 \mathrm{H}), 2.82(\mathrm{t}, J=6.1 \mathrm{~Hz}, 2 \mathrm{H}), 2.56(\mathrm{dd}, J=7.1,5.8 \mathrm{~Hz}, 2 \mathrm{H}), 2.06$ (p, $J=6.4 \mathrm{~Hz}, 2 \mathrm{H})$. ${ }^{13} \mathrm{C}$ NMR $\left(126 \mathrm{MHz}, \mathrm{CDCl}_{3}\right) \delta 196.99,151.36,147.14,129.89,124.17,113.26,112.59,38.98$, $30.16,23.49$.

6-diethylamino-1-tetralone (4). To a two-necked RBF equipped with reflux condenser were added 3 (3.00 g, $18.6 \mathrm{mmol}, 1.00 \mathrm{eq}$.), potassium carbonate (5.14 g, $37.2 \mathrm{mmol}, 2.0 \mathrm{eq}$.), and anhydrous DMF $(26 \mathrm{~mL})$ under a nitrogen atmosphere. The reaction mixture was heated to $60{ }^{\circ} \mathrm{C}$ for $20 \mathrm{~min}$. Ethyl iodide ( $4.49 \mathrm{~mL}, 55.8 \mathrm{mmol}, 3.0$ eq.) was added via syringe, and the reaction was heated overnight $(11 \mathrm{~h})$. Additional potassium carbonate $(2.57 \mathrm{~g}, 18.6 \mathrm{mmol}, 1.0 \mathrm{eq}$.$) and ethyl$ iodide ( $2 \mathrm{~mL}, 24.8 \mathrm{mmol}, 1.3$ eq.) was added, and the reaction was heated for an additional $24 \mathrm{~h}$. The reaction mixture was cooled, diluted in water, and extracted with ethyl acetate. The organic layers were washed with brine, dried with sodium sulfate, concentrated, and purified on silica gel by flash chromatography ( $15 \%$ ethyl acetate/hexanes) to yield a yellow-orange oil ( $2.45 \mathrm{~g}, 11.3$ mmol, 61\% yield). ${ }^{1} \mathrm{H}$ NMR (500 MHz, $\left.\mathrm{CDCl}_{3}\right) \delta 7.92$ (d, $\left.J=8.9 \mathrm{~Hz}, 1 \mathrm{H}\right), 6.55$ (dd, $J=9.0,2.6$ $\mathrm{Hz}, 1 \mathrm{H}), 6.35(\mathrm{~d}, J=2.6 \mathrm{~Hz}, 1 \mathrm{H}), 3.41(\mathrm{q}, J=7.1 \mathrm{~Hz}, 4 \mathrm{H}), 2.85(\mathrm{t}, J=6.1 \mathrm{~Hz}, 2 \mathrm{H}), 2.55(\mathrm{dd}, J=$ 7.2, $5.9 \mathrm{~Hz}, 2 \mathrm{H}), 2.07$ (tt, $J=7.1,5.7 \mathrm{~Hz}, 2 \mathrm{H}), 1.20(\mathrm{td}, J=7.1,1.3 \mathrm{~Hz}, 7 \mathrm{H}) \cdot{ }^{13} \mathrm{C} \mathrm{NMR}(126 \mathrm{MHz}$, $\left.\mathrm{CDCl}_{3}\right) \delta 196.64,151.37,146.91,129.73,121.25,109.86,108.77,44.58,38.94,30.82,23.70$, 12.71 .

7-methoxy-3-phenyl-4,5-dihydro-1 $\boldsymbol{H}$-benzo[g]indole (pyrrole b). To a $25 \mathrm{~mL}$ RBF were added $\mathrm{NaH}(278 \mathrm{mg}, 6.96 \mathrm{mmol}, 1.20$ eq.) and anhydrous DMSO $(5.80 \mathrm{~mL})$ under a nitrogen atmosphere. 6-methoxy-1-tetralone (1.02 g, $5.80 \mathrm{mmol}, 1.00$ eq.) was added and the reaction was stirred for 30 min at room temperature. The reaction vessel was placed in a cold-water bath and freshly prepared $2(0.679 \mathrm{~g}, 5.80 \mathrm{mmol}, 1.00$ eq.) was added dropwise. The reaction mixture was then stirred for one hour at room temperature. Upon completion by TLC, the reaction mixture was diluted with water and saturated sodium bicarbonate, and the aqueous layer was extracted with diethyl ether. The organic layer was dried over sodium sulfate and purified on silica gel by flash chromatography ( $10 \%$ to $15 \%$ ethyl acetate/hexanes). The product was isolated as a beige solid $(1.28 \mathrm{~g}, 4.65 \mathrm{mmol}$, 80\% yield). ${ }^{1} \mathrm{H}$ NMR (500 MHz, $\left.\mathrm{CDCl}_{3}\right) \delta 7.47-7.44(\mathrm{~m}, 2 \mathrm{H}), 7.41-7.36(\mathrm{~m}, 2 \mathrm{H}), 7.24$ (ddt, $J$ $=7.7,6.8,1.3 \mathrm{~Hz}, 1 \mathrm{H}), 7.13(\mathrm{~d}, J=8.3 \mathrm{~Hz}, 1 \mathrm{H}), 6.92(\mathrm{dd}, J=2.8,0.8 \mathrm{~Hz}, 1 \mathrm{H}), 6.83(\mathrm{~d}, J=2.6$ $\mathrm{Hz}, 1 \mathrm{H}), 6.76(\mathrm{dd}, J=8.3,2.7 \mathrm{~Hz}, 1 \mathrm{H}), 3.82(\mathrm{~d}, J=0.8 \mathrm{~Hz}, 3 \mathrm{H}), 2.93(\mathrm{~m}, 4 \mathrm{H}) .{ }^{13} \mathrm{C}$ NMR $(126$ 
$\left.\mathrm{MHz}, \mathrm{CDCl}_{3}\right) \delta 157.76,136.98,136.13,128.80,128.64,127.30,125.71,124.05,122.72,119.52$, $116.31,115.31,114.73,111.52,55.47,30.69,21.33$.

$\mathrm{N}, \mathrm{N}$-diethyl-3-phenyl-4,5-dihydro-1 $\mathrm{H}$-benzo[g]indol-7-amine (pyrrole d). A flame-dried 100 mL RBF was charged with 4 (1.59 g, $7.32 \mathrm{mmol}, 1.00$ eq.), anhydrous DMSO (45 mL), and sodium hydride (676 mg, $16.9 \mathrm{mmol}, 2.31$ eq.) and the reaction mixture was stirred for $20 \mathrm{~min} .2$ (1.19 g, $10.2 \mathrm{mmol}, 1.39$ eq.) was added dropwise and the reaction was stirred at room temperature overnight. Upon completion by TLC, the reaction mixture was diluted with brine and extracted with ethyl acetate. The organic layers were dried and concentrated to a solid residue, which was recrystallized in ethyl acetate/hexanes. The solids were isolated and the mother liquor was concentrated for further recrystallization, yielding off-white needles (1.54 $\mathrm{g}$ from three batches, $4.85 \mathrm{mmol}, 66 \%$ yield). ${ }^{1} \mathrm{H}$ NMR (500 MHz, DMSO- $\left.d_{6}\right) \delta 7.40(\mathrm{~d}, J=7.7 \mathrm{~Hz}, 2 \mathrm{H}), 7.31(\mathrm{t}, J=7.2$ $\mathrm{Hz}, 2 \mathrm{H}), 7.27(\mathrm{~d}, J=8.3 \mathrm{~Hz}, 1 \mathrm{H}), 7.16-7.09$ (m, 1H), 6.95 (dd, $J=2.8,1.2 \mathrm{~Hz}, 1 \mathrm{H}), 6.55$ (s, 1H), $6.50(\mathrm{~d}, J=8.8 \mathrm{~Hz}, 1 \mathrm{H}), 3.29(\mathrm{q}, J=6.8 \mathrm{~Hz}, 5 \mathrm{H}), 2.78(\mathrm{~d}, J=3.8 \mathrm{~Hz}, 2 \mathrm{H}), 2.48(\mathrm{dd}, J=3.5,1.9$ $\mathrm{Hz}, 2 \mathrm{H}), 1.07(\mathrm{t}, J=6.6 \mathrm{~Hz}, 7 \mathrm{H}) .{ }^{13} \mathrm{C}$ NMR $\left(126 \mathrm{MHz}, \mathrm{DMSO}-d_{6}\right) \delta 145.35,136.62,135.36$, $129.05,128.40,126.24,124.69,121.78,120.50,118.12,114.81,113.23,111.91,109.68,43.66$, $30.49,21.40,12.59$.

Scheme S2. Preparation of top-fused pyrroles $\boldsymbol{c}$ and $\boldsymbol{f}$.
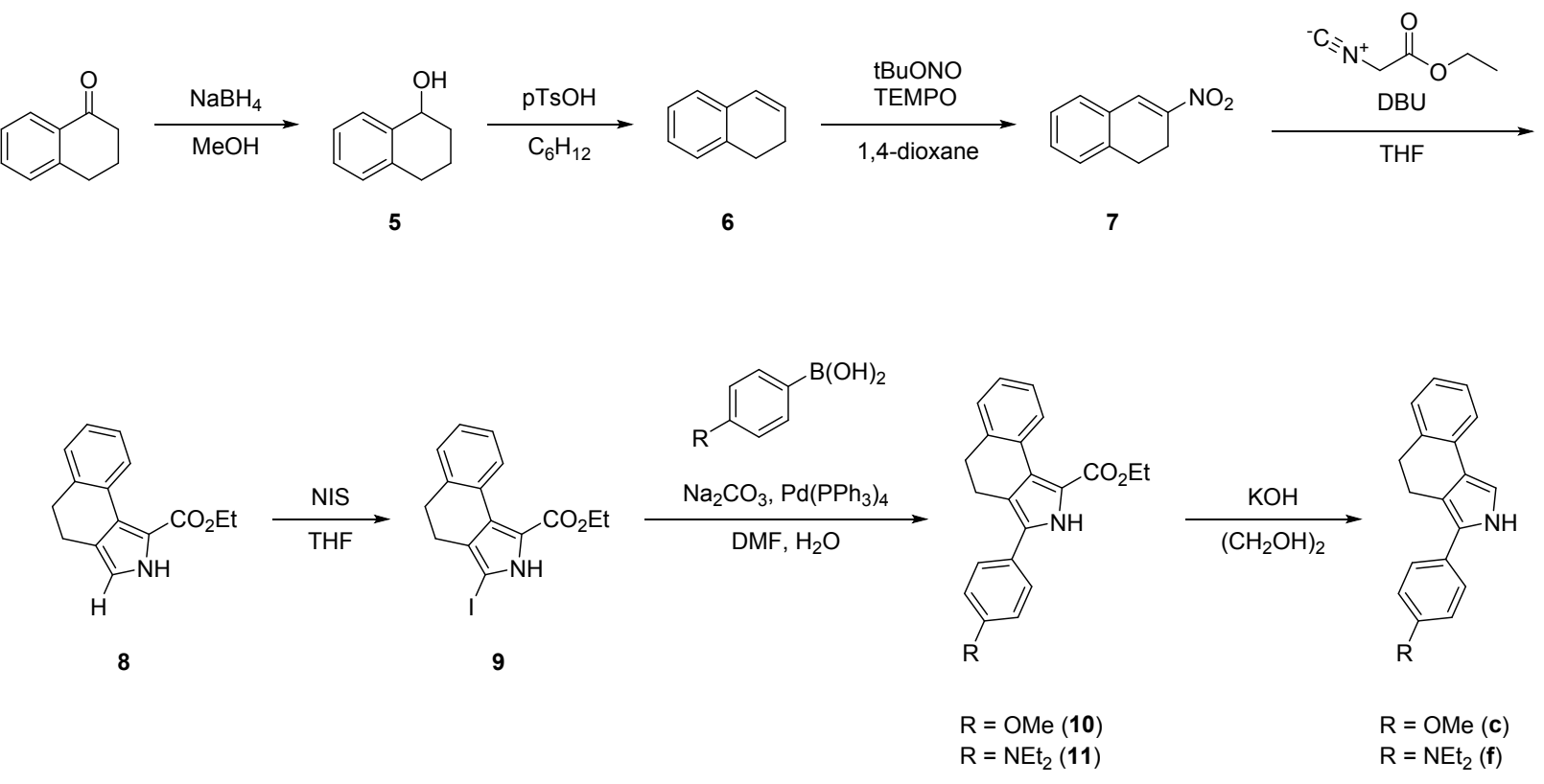
1,2,3,4-tetrahydro-1-naphthol (5). A 1 L RBF was charged with alpha-tetralone (20.0 g, 137 mmol, 1.0 eq.) and anhydrous methanol $(274 \mathrm{~mL})$. The solution was cooled to $0{ }^{\circ} \mathrm{C}$ and sodium borohydride (6.24 g, $164 \mathrm{mmol}, 1.2$ eq.) was added portionwise over $15 \mathrm{~min}$. The reaction vessel was brought to room temperature and stirred overnight $(12 \mathrm{~h})$ and concentrated. The crude residue was taken up in ethyl acetate and saturated ammonium chloride. The organic layer was dried over sodium sulfate, concentrated, and purified on silica gel by flash column chromatography (gradient, $10 \%$ to $50 \%$ ethyl acetate/hexanes) to yield a pale amber oil ( $20.1 \mathrm{~g}, 136 \mathrm{mmol}, 99 \%$ yield) which was used without further purification.

1,2-dihydronaphthalene (6). A $250 \mathrm{~mL}$ RBF was charged with 1,2,3,4-tetrahydro-1-naphthol (20.1 g, $136 \mathrm{mmol}, 1.0$ eq.), cyclohexane (108 mL), and pTsOH $\cdot \mathrm{H}_{2} \mathrm{O}(77 \mathrm{mg}, 0.41 \mathrm{mmol}, 0.003$ eq.). The reaction mixture was stirred at $80^{\circ} \mathrm{C}$ for $18 \mathrm{~h}$, cooled, and washed with an aqueous solution of sodium bicarbonate. The aqueous layer was extracted with ethyl acetate, and the combined organic layers were dried over sodium sulfate and concentrated to a crude residue. The crude product was purified by short hexane column to yield a clear oil (9.70 g, $74.5 \mathrm{mmol}, 55 \%$ yield). ${ }^{1} \mathrm{H}$ NMR (500 MHz, $\left.\mathrm{CDCl}_{3}\right) \delta 7.21-7.09(\mathrm{~m}, 3 \mathrm{H}), 7.07-7.02(\mathrm{~m}, 1 \mathrm{H}), 6.49$ (dt, $J=9.6$, $1.9 \mathrm{~Hz}, 1 \mathrm{H}), 6.05(\mathrm{dt}, J=9.1,4.3 \mathrm{~Hz}, 1 \mathrm{H}), 2.83$ (t, $J=8.2 \mathrm{~Hz}, 2 \mathrm{H}), 2.34(\mathrm{tdd}, J=8.1,4.4,1.8 \mathrm{~Hz}$, 2H). ${ }^{13} \mathrm{C} \mathrm{NMR}\left(126 \mathrm{MHz}, \mathrm{CDCl}_{3}\right) \delta 135.57,134.24,128.78,127.89,127.64,126.96,126.55$, $125.99,27.61,23.30$.

3-nitro-1,2-dihydronaphthalene (7). A large pressure flask was charged with 1,2dihydronaphthalene (1.74 g, $13.3 \mathrm{mmol}, 1.0$ eq.), 1,4-dioxane (56 mL), TEMPO (0.857 g, 5.48 mmol, 0.4 eq.), and tert-butyl nitrite (3.2 mL, $26.9 \mathrm{mmol}, 2.0$ eq.). The reaction mixture was stirred at $90{ }^{\circ} \mathrm{C}$ for $12 \mathrm{~h}$, cooled, diluted with brine, and extracted with ethyl acetate. The organic layer was dried over sodium sulfate and concentrated. The crude oil was purified on silica gel by flash column chromatography ( $3 \%$ ethyl acetate/hexanes) to yield a viscous oil that slowly crystallized to a pale yellow solid (1.69 g, $9.62 \mathrm{mmol}, 72 \%$ yield). ${ }^{1} \mathrm{H} \mathrm{NMR}\left(400 \mathrm{MHz}, \mathrm{CDCl}_{3}\right) \delta 7.84(\mathrm{q}, J=$ $1.1 \mathrm{~Hz}, 1 \mathrm{H}), 7.40-7.20(\mathrm{~m}, 4 \mathrm{H}), 3.06(\mathrm{dd}, J=9.1,5.9 \mathrm{~Hz}, 2 \mathrm{H}), 3.02-2.94(\mathrm{~m}, 2 \mathrm{H}) .{ }^{13} \mathrm{C}$ NMR $\left(126 \mathrm{MHz}, \mathrm{CDCl}_{3}\right) \delta 147.94,136.45,131.61,131.31,130.21,130.14,127.96,127.36,27.95$, 22.42 .

Ethyl 4,5-dihydro-2H-benzo[e]isoindole-1-carboxylate (8). A $100 \mathrm{~mL}$ RBF was charged with 3-nitro-1,2-dihydronaphthalene (2.92 g, $16.6 \mathrm{mmol}, 1.0 \mathrm{eq}$.), THF (20 mL), ethyl isocyanoacetate 
(1.81 mL, $16.6 \mathrm{mmol}, 1.0$ eq.), and DBU (2.51 mL, $16.6 \mathrm{mmol}, 1.0$ eq.) under a nitrogen atmosphere. The reaction mixture was stirred at room temperature for $18 \mathrm{~h}$ and formed a thick slurry. The reaction mixture was concentrated and purified on silica gel by flash column chromatography (10\% ethyl acetate/hexanes) to yield a clear oil (3.91 g, $16.2 \mathrm{mmol}, 98 \%$ yield). ${ }^{1} \mathrm{H}$ NMR (500 MHz, CDCl3) $\delta 9.06(\mathrm{~s}, 1 \mathrm{H}), 8.48(\mathrm{~d}, J=7.9 \mathrm{~Hz}, 1 \mathrm{H}), 7.32-7.28(\mathrm{~m}, 1 \mathrm{H}), 7.25$ (d, $J=7.3 \mathrm{~Hz}, 1 \mathrm{H}), 7.19(\mathrm{td}, J=7.4,1.4 \mathrm{~Hz}, 1 \mathrm{H}), 6.77$ (d, $J=2.9 \mathrm{~Hz}, 1 \mathrm{H}), 4.40(\mathrm{q}, J=7.1 \mathrm{~Hz}, 2 \mathrm{H})$, $2.87(\mathrm{dd}, J=8.4,5.7 \mathrm{~Hz}, 2 \mathrm{H}), 2.68(\mathrm{dd}, J=8.3,5.7 \mathrm{~Hz}, 2 \mathrm{H}), 1.42(\mathrm{t}, J=7.1 \mathrm{~Hz}, 3 \mathrm{H}) .{ }^{13} \mathrm{C}$ NMR $\left(126 \mathrm{MHz}, \mathrm{CDCl}_{3}\right) \delta 161.16,137.82,130.97,128.20,127.74,127.02,126.68,126.62,124.38$, $117.69,117.40,60.64,31.85,22.91,14.36$.

Ethyl 3-iodo-4,5-dihydro-2H-benzo[e]isoindole-1-carboxylate (9). A $250 \mathrm{~mL}$ RBF was charged with 8 (3.91 g, $16.2 \mathrm{mmol}, 1.0$ eq.), THF ( $32 \mathrm{~mL}$ ), and $N$-iodosuccinimide (4.00 g, $17.8 \mathrm{mmol}, 1.1$ eq.) under nitrogen atmosphere. The reaction was stirred overnight $(12 \mathrm{~h})$ at room temperature, concentrated to a solid, and taken up into ethyl acetate. The organic layer was washed with brine and a $10 \%$ solution of sodium sulfite, dried over sodium sulfate, concentrated in ethyl acetate, and triturated in $25 \%$ ethyl acetate/hexanes to yield a solid ( $3.61 \mathrm{~g}, 9.80 \mathrm{mmol}, 61 \%$ yield). ${ }^{1} \mathrm{H}$ NMR $\left(500 \mathrm{MHz}, \mathrm{CDCl}_{3}\right) \delta 9.09(\mathrm{~s}, 1 \mathrm{H}), 8.45(\mathrm{dd}, J=7.9,1.3 \mathrm{~Hz}, 1 \mathrm{H}), 7.34-7.18(\mathrm{~m}, 3 \mathrm{H}), 4.43$ (q, $J=$ $7.1 \mathrm{~Hz}, 2 \mathrm{H}), 2.89$ (dd, $J=8.2,6.1 \mathrm{~Hz}, 2 \mathrm{H}), 2.62-2.53(\mathrm{~m}, 2 \mathrm{H}), 1.44(\mathrm{t}, J=7.2 \mathrm{~Hz}, 3 \mathrm{H}) .{ }^{13} \mathrm{C}$ NMR $\left(126 \mathrm{MHz}, \mathrm{CDCl}_{3}\right) \delta 160.06,137.51,130.22,130.08,128.23,127.62,127.48,126.60,121.91$, $69.89,60.91,30.76,22.41,14.60$.

ethyl 3-(4-methoxyphenyl)-4,5-dihydro-2H-benzo[e]isoindole-1-carboxylate (10). A $25 \mathrm{~mL}$ RBF was charged with 9 (109 mg, $0.298 \mathrm{mmol}, 1.0$ eq.), 4-methoxyphenylboronic acid (73.5 mg, $0.484 \mathrm{mmol}, 1.6$ eq.), $\mathrm{Pd}\left(\mathrm{PPh}_{3}\right)_{4}(17.4 \mathrm{mg}, 0.0151 \mathrm{mmol}, 0.051$ eq.), and sodium carbonate ( 99.9 $\mathrm{mg}, 0.943 \mathrm{mmol}, 3.2 \mathrm{eq}$.). The flask was evacuated and back-filled with nitrogen three times. Nitrogen-purged DMF $(2.25 \mathrm{~mL})$ and deionized water $(0.75 \mathrm{~mL})$ were added via syringe, and the reaction mixture was stirred at $150^{\circ} \mathrm{C}$ for $6 \mathrm{~h}$, forming a black solution. The reaction mixture was cooled, diluted with brine, and extracted with ethyl acetate. The organic layers were combined, dried, concentrated, and purified on silica gel by flash column chromatography (gradient, 15\% ethyl acetate/hexanes to $25 \%$ ethyl acetate/hexanes) to yield an off-white solid ( $84.3 \mathrm{mg}, 0.243$ mmol, 81\% yield). ${ }^{1} \mathrm{H}$ NMR (500 MHz, $\mathrm{CDCl}_{3}$ ) $\delta 8.99$ (s, $\left.1 \mathrm{H}\right), 8.47$ (dd, $J=7.9,1.3 \mathrm{~Hz}, 1 \mathrm{H}$ ), 7.46 $-7.40(\mathrm{~m}, 2 \mathrm{H}), 7.29(\mathrm{td}, J=7.5,1.6 \mathrm{~Hz}, 1 \mathrm{H}), 7.26-7.23(\mathrm{~m}, 1 \mathrm{H}), 7.20(\mathrm{td}, J=7.3,1.4 \mathrm{~Hz}, 1 \mathrm{H})$, 
$7.03-6.98(\mathrm{~m}, 2 \mathrm{H}), 4.41(\mathrm{q}, J=7.1 \mathrm{~Hz}, 2 \mathrm{H}), 3.86(\mathrm{~s}, 3 \mathrm{H}), 2.91-2.83(\mathrm{~m}, 2 \mathrm{H}), 2.83-2.75(\mathrm{~m}$, 2H), 1.43 (t, $J=7.1 \mathrm{~Hz}, 3 \mathrm{H}) .{ }^{13} \mathrm{C} \mathrm{NMR}\left(126 \mathrm{MHz}, \mathrm{CDCl}_{3}\right) \delta 161.18,159.42,137.70,131.02$, 130.69 , 128.36, 127.98, 127.92, 127.78, 127.04, 126.48, 124.37, 120.72, 116.52, 114.56, 60.61, $55.55,31.23,21.12,14.69$.

3-(4-methoxyphenyl)-4,5-dihydro-2H-benzo[e]isoindole (pyrrole c). A $4 \mathrm{~mL}$ vial was charged with 10 (86.9 mg, $0.250 \mathrm{mmol}, 1.0$ eq.), finely ground potassium hydroxide $(70.8 \mathrm{mg}, 1.26 \mathrm{mmol}$, 5.0 eq.), and ethylene glycol $(2.5 \mathrm{~mL})$. The vial was sealed and heated to $185^{\circ} \mathrm{C}$ for $1 \mathrm{~h}$. The reaction mixture was poured directly into cold water to precipitate the product, which was isolated by vacuum filtration under nitrogen to yield off-white crystals (32.2 mg, $0.117 \mathrm{mmol}, 47 \%$ yield) which were used without purification.

ethyl 3-(4-(diethylamino)phenyl)-4,5-dihydro-2H-benzo[e]isoindole-1-carboxylate (11). A 25 mL RBF was charged with 9 (95.5 mg, $0.260 \mathrm{mmol}, 1.0$ eq.), 4-methoxyphenylboronic acid (80.0 $\mathrm{mg}, 0.414 \mathrm{mmol}, 1.6$ eq.), palladium tetrakis $(15.0 \mathrm{mg}, 0.0130 \mathrm{mmol}, 0.050$ eq.), and sodium carbonate $(82.0 \mathrm{mg}, 0.774 \mathrm{mmol}, 3.0$ eq.). The flask was evacuated and back-filled with nitrogen three times. Nitrogen-purged DMF $(2 \mathrm{~mL})$ and deionized water $(0.65 \mathrm{~mL})$ were added via syringe, and the reaction mixture was stirred at $150{ }^{\circ} \mathrm{C}$ for $3 \mathrm{~h}$. The reaction mixture was cooled, diluted with brine, and extracted with ethyl acetate. The organic layers were combined, dried, concentrated, and purified on silica gel by flash column chromatography (15\% ethyl acetate/hexanes) to yield an off-white powder (74.6 mg, $0.192 \mathrm{mmol}, 74 \%$ yield). ${ }^{1} \mathrm{H}$ NMR (500 $\left.\mathrm{MHz}, \mathrm{CDCl}_{3}\right) \delta 9.06(\mathrm{~s}, 1 \mathrm{H}), 8.46(\mathrm{~d}, J=7.7 \mathrm{~Hz}, 1 \mathrm{H}), 7.37(\mathrm{~d}, J=8.4 \mathrm{~Hz}, 2 \mathrm{H}), 7.29-7.22(\mathrm{~m}$, 2H), $7.18(\mathrm{t}, J=7.2 \mathrm{~Hz}, 1 \mathrm{H}), 6.76(\mathrm{~d}, J=8.4 \mathrm{~Hz}, 2 \mathrm{H}), 4.38(\mathrm{q}, J=7.1 \mathrm{~Hz}, 2 \mathrm{H}), 3.41$ (q, $J=7.1$ $\mathrm{Hz}, 4 \mathrm{H}), 2.89-2.74(\mathrm{~m}, 4 \mathrm{H}), 1.41(\mathrm{t}, J=7.2 \mathrm{~Hz}, 3 \mathrm{H}), 1.20(\mathrm{t}, J=7.1 \mathrm{~Hz}, 6 \mathrm{H}) .{ }^{13} \mathrm{C}$ NMR $(126$ $\left.\mathrm{MHz}, \mathrm{CDCl}_{3}\right) \delta 161.39,147.95,138.29,132.11,131.72,128.53,128.34,128.15,127.24,126.66$, $120.16,118.75,116.25,112.22,60.82,44.93,31.71,21.68,14.91,12.93$.

4-(4,5-dihydro-2H-benzo[e]isoindol-3-yl)- $\mathbf{N}, \mathbf{N}$-dimethylaniline (pyrrole $\mathbf{f}$ ). A $4 \mathrm{~mL}$ vial was charged with 11 (86.9 mg, $0.250 \mathrm{mmol}, 1.0$ eq.), finely ground potassium hydroxide (70.8 mg, $1.26 \mathrm{mmol}, 5.0$ eq.), and ethylene glycol $(2.5 \mathrm{~mL})$. The vial was sealed and heated to $185^{\circ} \mathrm{C}$ for 1 h. The reaction mixture was poured directly into cold water to precipitate the product. The solid was isolated by vacuum filtration under nitrogen to yield off-white crystals $(32.2 \mathrm{mg}, 0.117 \mathrm{mmol}$, $47 \%$ yield) which were used without purification. 
Scheme S3. Preparation of unfused pyrroles.
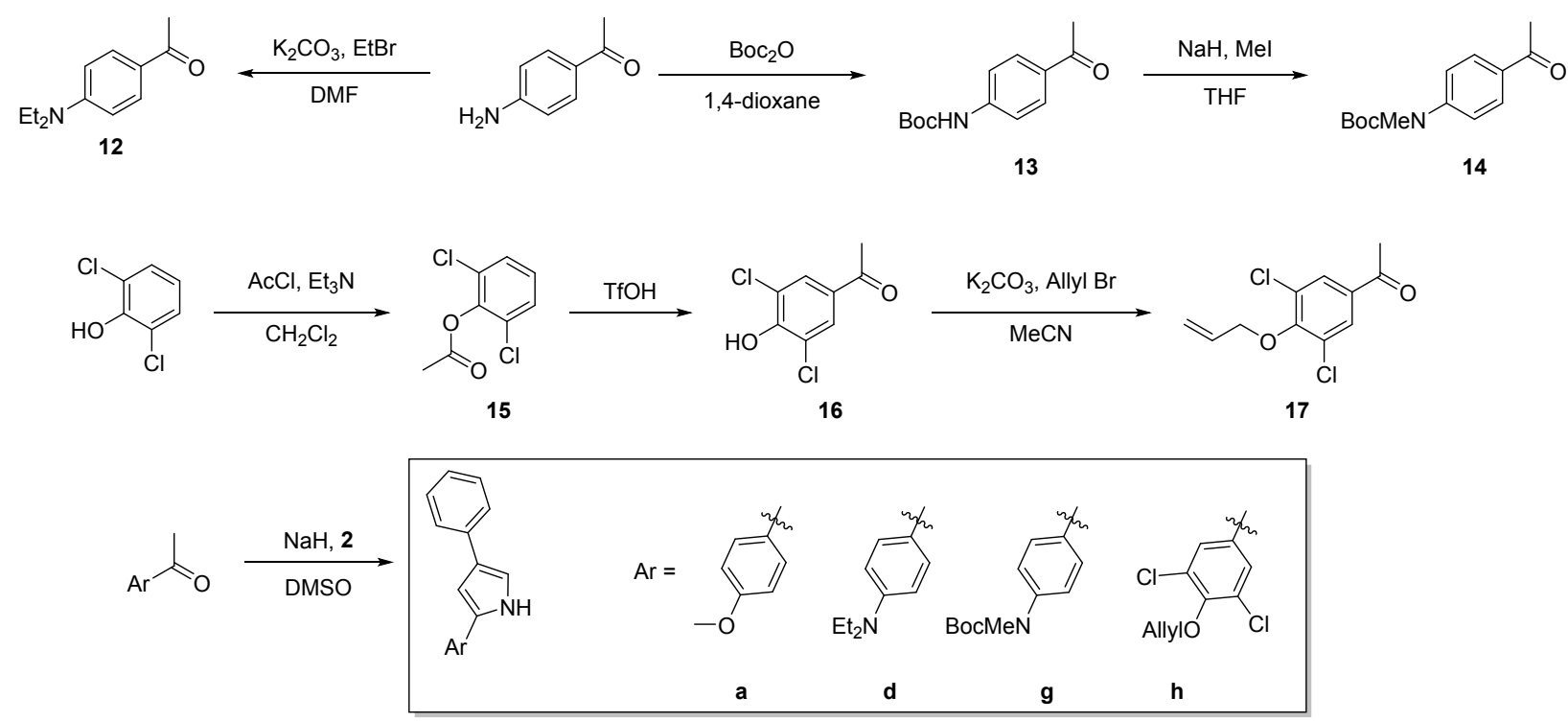

4-diethylaminoacetophenone (12). A $50 \mathrm{~mL} \mathrm{RBF}$ was charged with 4-aminoacetophenone (1.00 g, $7.50 \mathrm{mmol}, 1.0$ eq.), potassium carbonate (2.28 g, $16.5 \mathrm{mmol}, 2.2$ eq.), DMF (7.5 mL), and bromoethane (1.2 mL, $16.5 \mathrm{mmol}, 2.2$ eq.). The reaction mixture was heated to $60{ }^{\circ} \mathrm{C}$ for $24 \mathrm{~h}$. The reaction mixture was cooled, diluted with water, and extracted with diethyl ether. The organic layer was washed with brine, dried over sodium sulfate, and purified on silica gel by flash column chromatography (15\% to $30 \%$ ethyl acetate/hexanes with $0.1 \%$ triethylamine) to obtain a pale oil that slowly solidified (350 mg, $1.83 \mathrm{mmol}, 24 \%$ yield). ${ }^{1} \mathrm{H} \mathrm{NMR}\left(500 \mathrm{MHz}, \mathrm{CDCl}_{3}\right) \delta 7.84(\mathrm{~d}, J$ $=9.1 \mathrm{~Hz}, 2 \mathrm{H}), 6.61(\mathrm{~d}, J=9.1 \mathrm{~Hz}, 2 \mathrm{H}), 3.41(\mathrm{q}, J=7.1 \mathrm{~Hz}, 5 \mathrm{H}), 2.48$ (s, 4H), 1.19 (t, $J=7.1 \mathrm{~Hz}$, 8H). ${ }^{13} \mathrm{C} \mathrm{NMR}\left(126 \mathrm{MHz}, \mathrm{CDCl}_{3}\right) \delta 196.18,151.20,130.94,124.70,110.15,44.61,26.00,12.60$.

tert-butyl (4-acetylphenyl)carbamate (13). To a $250 \mathrm{~mL}$ round-bottomed flask (RBF) were added 4'-aminoacetophenone ( $6.7 \mathrm{~g}, 50 \mathrm{mmol}, 1.0$ equiv) and di-tert-butyl dicarbonate ( $13.1 \mathrm{~g}, 60$ $\mathrm{mmol}, 1.2$ equiv). The reaction vessel was capped and flushed with nitrogen. 1,4-Dioxane ( $60 \mathrm{~mL})$ was added, and the solution was heated to $100{ }^{\circ} \mathrm{C}$ for $8.5 \mathrm{~h}$. The reaction was cooled and concentrated to an oil that crystallized to a solid. The solid was washed with 1:3 ethyl acetate/hexanes to give one batch of pure product. The filtrate was then concentrated to a solid and washed with 1:4 ethyl acetate/hexanes to afford a second batch of pure product (total: $10.1 \mathrm{~g}, 43$ mmol, 86\% yield). ${ }^{1} \mathrm{H}$ NMR (400 MHz, $\left.\mathrm{CDCl}_{3}\right) \delta 7.89$ (d, J = 8.4 Hz, 2H), $7.46(\mathrm{~d}, \mathrm{~J}=8.3 \mathrm{~Hz}$, 
2H), 2.55 (s, 3H), 1.50 (s, 9H). ${ }^{13} \mathrm{C}$ NMR (125 MHz, $\left.\mathrm{CDCl}_{3}\right) \delta 197.13,152.35,143.15,131.84$, $129.94,117.53,81.35,28.37,26.49$

tert-butyl (4-acetylphenyl)(methyl)carbamate (14). To a $250 \mathrm{~mL}$ RBF were added 13 (3.0 g, $12.8 \mathrm{mmol}, 1.0$ equiv) and anhydrous THF $(40 \mathrm{~mL})$ under nitrogen. The reaction mixture was cooled to $0{ }^{\circ} \mathrm{C}$, and sodium hydride (60 wt \% dispersion in mineral oil) $(0.61 \mathrm{~g}, 15.3 \mathrm{mmol}, 1.2$ equiv) was added portion-wise over the course of $10 \mathrm{~min}$. After $20 \mathrm{~min}$, methyl iodide (1.57 mL, $31.9 \mathrm{mmol}, 2.5$ equiv) was added, and the white suspension was warmed to room temperature and stirred until it formed an amber solution. After $40 \mathrm{~min}$ at this temperature, completion was noted by TLC (3:17 ethyl acetate/hexanes); the reaction mixture was concentrated, and the crude residue was taken up in ethyl acetate and washed with brine $(3 \times)$. The organic layer was dried over sodium sulfate and concentrated to a yellow oil (quantitative yield). ${ }^{1} \mathrm{H}$ NMR $\left(500 \mathrm{MHz}, \mathrm{CDCl}_{3}\right) \delta 7.93$ (d, $J=8.8 \mathrm{~Hz}, 2 \mathrm{H}), 7.37$ (d, $J=8.7 \mathrm{~Hz}, 2 \mathrm{H}), 3.32$ (s, 3H), 2.59 (s, 3H), 1.49 (s, 9H). ${ }^{13} \mathrm{C}$ NMR $\left(126 \mathrm{MHz}, \mathrm{CDCl}_{3}\right) \delta 197.10,154.09,148.06,133.42,128.83,124.35,81.14,36.83,28.28,26.52$.

2,6-dichlorophenyl acetate (15). A $100 \mathrm{~mL}$ RBF was charged with 2,6-dichlorophenol (3.26 g, $20 \mathrm{mmol}, 1.0$ eq.), dichloromethane ( $36 \mathrm{~mL})$, and triethylamine $(7.0 \mathrm{~mL}, 50 \mathrm{mmol}, 2.5$ eq.). The reaction mixture was cooled to $0{ }^{\circ} \mathrm{C}$. Acetyl chloride $(1.70 \mathrm{~mL}, 24 \mathrm{mmol}, 1.2$ eq.) was added dropwise, and the thick yellow slurry was warmed to room temperature and stirred for $4 \mathrm{~h}$. Upon completion by TLC, the reaction was quenched with aqueous sodium bicarbonate, and the organic layer was dried over sodium sulfate and concentrated to a yellow oil. The product was used without purification.

3,5-dichloro-5-hydroxyacetophenone (16). A $50 \mathrm{~mL}$ RBF was charged with 15 (450 mg, 1.55 mmol, 1.0 eq.) and triflic acid $(7 \mathrm{~mL})$. The reaction mixture was heated to $40{ }^{\circ} \mathrm{C}$ for $18 \mathrm{~h}$, cooled to $0{ }^{\circ} \mathrm{C}$, and basified with saturated sodium carbonate. The solution was washed with ethyl acetate to remove residual starting material. The aqueous layer was then acidified with $1 \mathrm{M} \mathrm{HCl}$ and extracted with ethyl acetate to isolate product ( $1.64 \mathrm{~g}, 8.02 \mathrm{mmol}, 40 \%$ yield). The product was used without purification.

1-(4-(allyloxy)-3,5-dichlorophenyl)ethan-1-one (17). A $25 \mathrm{~mL}$ RBF was charged with 16 (500 $\mathrm{mg}, 2.44 \mathrm{mmol}, 1.0$ eq.), potassium carbonate ( $674 \mathrm{mg}, 4.88 \mathrm{mmol}, 2.0$ eq.), acetonitrile ( $2.4 \mathrm{~mL})$, and allyl bromide ( $337 \mu \mathrm{L}, 3.90 \mathrm{mmol}, 1.6$ eq.) and the reaction mixture was refluxed for $4.5 \mathrm{~h}$. The crude reaction mixture was concentrated and purified on silica gel by flash column 
chromatography (10\% ethyl acetate/hexanes) to yield a clear oil (397 mg, $1.62 \mathrm{mmol}, 66 \%$ yield). ${ }^{1} \mathrm{H}$ NMR (400 MHz, $\mathrm{CDCl}_{3}$ ) $\delta 7.87$ (d, $J=0.8 \mathrm{~Hz}, 2 \mathrm{H}$ ), 6.12 (ddtd, $J=17.2,10.4,6.0,0.8 \mathrm{~Hz}$, $1 \mathrm{H}), 5.47-5.35(\mathrm{~m}, 1 \mathrm{H}), 5.29(\mathrm{dt}, J=10.3,1.2 \mathrm{~Hz}, 1 \mathrm{H}), 4.62(\mathrm{dq}, J=6.0,1.1 \mathrm{~Hz}, 2 \mathrm{H}), 2.55(\mathrm{~s}$, 3H). ${ }^{13} \mathrm{C}$ NMR (101 MHz, $\left.\mathrm{CDCl}_{3}\right) \delta 194.87,155.10,133.98,132.57,130.21,129.13,119.51$, $74.71,26.54$.

2-(4-methoxyphenyl)-4-phenyl-1H-pyrrole (pyrrole a). A $25 \mathrm{~mL}$ RBF was charged with 4methoxyacetophenone $(861 \mathrm{mg}, 5.73 \mathrm{mmol}, 1.0$ eq.) and anhydrous DMSO $(5.7 \mathrm{~mL})$. Sodium hydride ( $60 \% \mathrm{wt}$ in mineral oil) ( $272 \mathrm{mg}, 6.80 \mathrm{mmol}, 1.2 \mathrm{eq}$.) was added and the reaction mixture was stirred at room temperature. After $15 \mathrm{~min}, 2(800 \mathrm{mg}, 6.83 \mathrm{mmol}, 1.2 \mathrm{eq}$.) was added and the reaction was stirred at room temperature overnight. The reaction mixture was then diluted in brine and extracted with ethyl acetate. The organic layers were combined, dried, and concentrated to a brown solid that was triturated in 3:2 ethyl acetate/hexanes to yield an off-white crystalline solid (421.6 mg, $1.69 \mathrm{mmol}, 30 \%$ yield). ${ }^{1} \mathrm{H}$ NMR (500 MHz, $\left.\mathrm{CDCl}_{3}\right) \delta 11.28(\mathrm{~s}, 1 \mathrm{H}), 7.64-7.55$ (m, 4H), $7.33-7.28$ (m, 2H), 7.27 (dd, $J=2.7,1.7 \mathrm{~Hz}, 1 \mathrm{H}), 7.11$ (ddt, $J=8.5,7.5,1.2 \mathrm{~Hz}, 1 \mathrm{H}), 6.98$ $-6.92(\mathrm{~m}, 2 \mathrm{H}), 6.81(\mathrm{dd}, J=2.7,1.7 \mathrm{~Hz}, 1 \mathrm{H}), 3.77$ (s, 3H). ${ }^{13} \mathrm{C} \mathrm{NMR}\left(126 \mathrm{MHz}, \mathrm{CDCl}_{3}\right) \delta 158.49$, 135.64, 133.13, 128.63, 126.50, 125.66, 125.57, 125.31, 125.17, 114.85, 114.41, 103.00, 55.38.

$\boldsymbol{N}, \boldsymbol{N}$-diethyl-4-(4-phenyl-1H-pyrrol-2-yl)aniline (pyrrole d). A $25 \mathrm{~mL} \mathrm{RBF}$ was charged with sodium hydride (246 mg, $6.15 \mathrm{mmol}, 3.4$ eq.) and anhydrous DMSO (1.5 mL). 12 (350 mg, 1.83 mmol, 1.0 eq.) was added at room temperature, and the reaction mixture was stirred for $20 \mathrm{~min} .2$ (679 mg, $5.8 \mathrm{mmol}, 3.4 \mathrm{eq}$.) was added, and the reaction was stirred at room temperature for $8 \mathrm{~h}$. The reaction mixture was diluted with water and extracted with diethyl ether. The organic layer was washed with brine, dried over sodium sulfate, and concentrated to an orange solid. The solid was purified on neutral alumina by flash column chromatography (15\% to $35 \%$ ethyl acetate/hexanes) to yield a beige solid (450 mg, $1.55 \mathrm{mmol}, 85 \%$ yield). ${ }^{1} \mathrm{H}$ NMR (500 MHz, DMSO- $\left.d_{6}\right) \delta 11.11(\mathrm{~s}, 1 \mathrm{H}), 7.57(\mathrm{~d}, J=7.6 \mathrm{~Hz}, 2 \mathrm{H}), 7.47(\mathrm{~d}, J=8.3 \mathrm{~Hz}, 2 \mathrm{H}), 7.30(\mathrm{t}, J=7.6 \mathrm{~Hz}$, 2H), 7.19 (s, 1H), $7.10(\mathrm{t}, J=7.3 \mathrm{~Hz}, 1 \mathrm{H}), 6.67$ (m, 3H), $3.42-3.27$ (m, 4H), 1.09 (t, $J=7.0 \mathrm{~Hz}$, $6 \mathrm{H}) .{ }^{13} \mathrm{C}$ NMR (126 MHz, DMSO- $\left.d_{6}\right) \delta 145.78,136.09,133.25,128.47,124.80,124.73,124.29$, $120.21,114.80,111.75,100.43,43.63,12.51$.

tert-butyl methyl(4-(4-phenyl-1H-pyrrol-2-yl)phenyl)carbamate (pyrrole g). A $25 \mathrm{~mL} \mathrm{RBF}$ was charged with sodium hydride (48 mg, $1.2 \mathrm{mmol}, 1.2 \mathrm{eq}$.) and anhydrous DMSO (1.0 mL). 14 
(250 mg, $1.0 \mathrm{mmol}, 1.0$ eq.) was added at room temperature, and the reaction was stirred for $1 \mathrm{~h}$. 2 (140 mg, $1.20 \mathrm{mmol}, 1.2$ eq.) was added and the reaction was stirred for $1 \mathrm{~h}$. The reaction mixture was diluted with water and extracted with diethyl ether. The organic layer was washed with brine, dried over sodium sulfate, and purified by flash column chromatography (15\% to $30 \%$ ethyl acetate/hexanes) to yield a pale green oil which was dried under vacuum to yield a yellow foam (132 mg, $0.38 \mathrm{mmol}, 38 \%$ yield). ${ }^{1} \mathrm{H}$ NMR (500 MHz, $\left.\mathrm{CDCl}_{3}\right) \delta 8.45$ (s, 1H), $7.52-7.46(\mathrm{~m}, 2 \mathrm{H})$, $7.41-7.36(\mathrm{~m}, 2 \mathrm{H}), 7.28(\mathrm{t}, J=7.7 \mathrm{~Hz}, 2 \mathrm{H}), 7.20-7.16(\mathrm{~m}, 1 \mathrm{H}), 7.13(\mathrm{td}, J=7.2,1.2 \mathrm{~Hz}, 1 \mathrm{H})$, $7.05(\mathrm{dq}, J=3.8,2.2 \mathrm{~Hz}, 1 \mathrm{H}), 6.71(\mathrm{dd}, J=2.7,1.6 \mathrm{~Hz}, 1 \mathrm{H}), 3.20(\mathrm{~s}, 3 \mathrm{H}), 1.40(\mathrm{~s}, 9 \mathrm{H}) .{ }^{13} \mathrm{C}$ NMR $\left(126 \mathrm{MHz}, \mathrm{CDCl}_{3}\right) \delta 154.79,142.11,135.49,132.65,129.68,128.65,125.88,125.74,125.17$, $124.03,115.54,103.93,80.46,37.28,28.38,28.35,28.30$.

2-(4-(allyloxy)-3,5-dichlorophenyl)-4-phenyl-1H-pyrrole (pyrrole h). A $25 \mathrm{~mL}$ RBF was charged with sodium hydride (60\% wt. in mineral oil) (48 mg, $1.20 \mathrm{mmol}, 1.0$ eq.) and anhydrous DMSO (1 mL). 17 (245 mg, $1.00 \mathrm{mmol}, 1.0$ eq.) was added and the reaction was stirred for 40 min. 2 (140 mg, $1.20 \mathrm{mmol}, 1.2$ eq.) was added and the reaction was stirred for $1 \mathrm{~h}$. The reaction mixture was then diluted in water and extracted with diethyl ether. The organic layer was dried over sodium sulfate, concentrated, and purified on silica gel by flash column chromatography ( $8 \%$ to $15 \%$ ethyl acetate/hexanes) to yield a beige solid (230 mg, $0.67 \mathrm{mmol}, 67 \%$ yield). ${ }^{1} \mathrm{H}$ NMR $\left(500 \mathrm{MHz}, \mathrm{CDCl}_{3}\right) \delta 8.35(\mathrm{~s}, 1 \mathrm{H}), 7.59-7.51(\mathrm{~m}, 2 \mathrm{H}), 7.40(\mathrm{~s}, 2 \mathrm{H}), 7.38(\mathrm{t}, J=7.7 \mathrm{~Hz}, 2 \mathrm{H}), 7.25$ $-7.21(\mathrm{~m}, 1 \mathrm{H}), 7.13-7.10(\mathrm{~m}, 1 \mathrm{H}), 6.78(\mathrm{dd}, J=2.8,1.7 \mathrm{~Hz}, 1 \mathrm{H}), 6.18$ (ddt, $J=16.5,10.3,6.0$ $\mathrm{Hz}, 1 \mathrm{H}), 5.46(\mathrm{dq}, J=17.2,1.5 \mathrm{~Hz}, 1 \mathrm{H}), 5.35-5.29(\mathrm{~m}, 1 \mathrm{H}), 4.60(\mathrm{dt}, J=6.0,1.4 \mathrm{~Hz}, 2 \mathrm{H}) .{ }^{13} \mathrm{C}$ NMR $\left(126 \mathrm{MHz}, \mathrm{CDCl}_{3}\right) \delta 149.43,135.12,133.07,130.32,130.23,130.21,128.87,127.04$, $126.16,125.29,124.11,119.13,116.62,105.24,74.69$. 
Scheme S4. Synthesis of analyte-responsive CRaB probes.
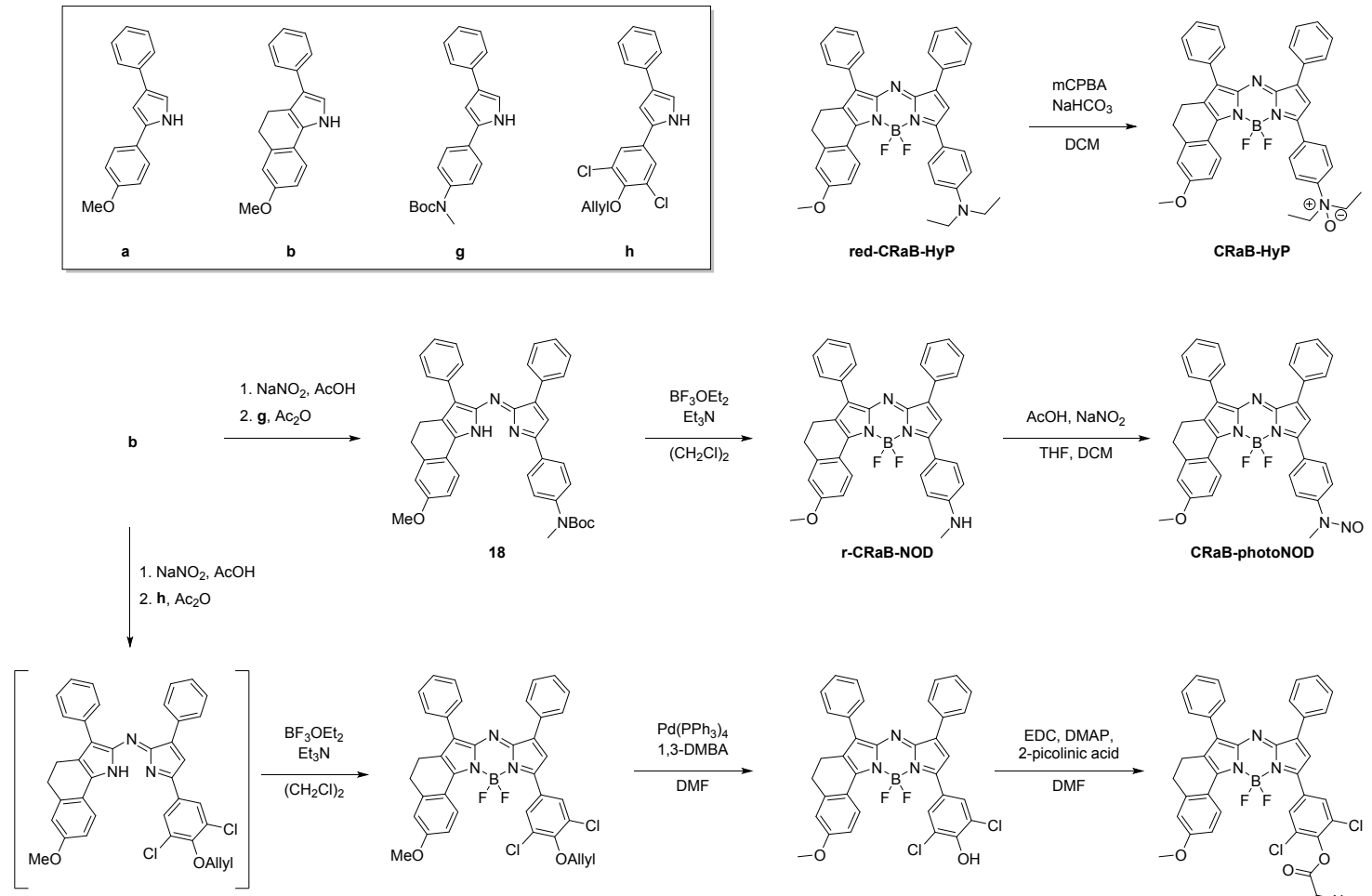

t-CRaB-OMe-APC
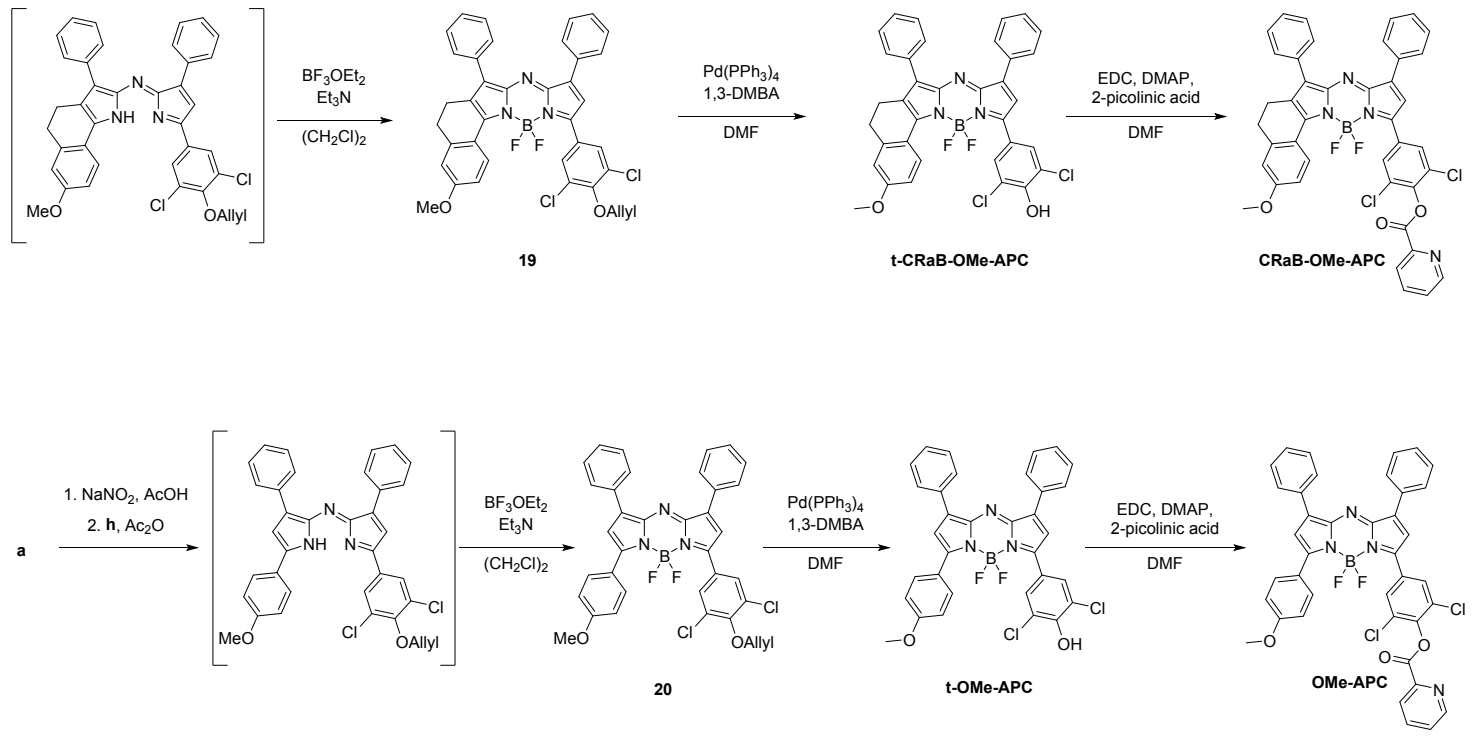

CRaB-HyP. A $25 \mathrm{~mL}$ RBF was charged with red-CRaB-HyP (100 mg, $0.16 \mathrm{mmol}, 1.0$ eq.), dichloromethane $(3.2 \mathrm{~mL})$, and sodium bicarbonate $(14.8 \mathrm{mg}, 0.176 \mathrm{mmol}, 1.1 \mathrm{eq}$.). The reaction mixture was cooled to $0{ }^{\circ} \mathrm{C}$. $\mathrm{mCPBA}(77 \%$ wt.) $(39.6 \mathrm{mg}, 0.176 \mathrm{mmol}, 1.1$ eq.) was added and the reaction mixture was stirred for $5 \mathrm{~min}$ at this temperature before warming to room temperature and stirring for $25 \mathrm{~min}$. The reaction mixture was diluted with a saturated solution of sodium bicarbonate and extracted with ethyl acetate. The organic layer was dried over sodium sulfate and purified by silica column chromatography ( $10 \%$ methanol/dichloromethane) to provide the product $\left(8.0 \mathrm{mg}, 0.012 \mathrm{mmol}, 8 \%\right.$ yield). ${ }^{1} \mathrm{H} \mathrm{NMR}\left(500 \mathrm{MHz}, \mathrm{CDCl}_{3}\right) \delta 8.74(\mathrm{~d}, J=9.0 \mathrm{~Hz}, 1 \mathrm{H})$, $8.16(\mathrm{~d}, J=8.4 \mathrm{~Hz}, 2 \mathrm{H}), 8.06(\mathrm{~d}, J=7.6 \mathrm{~Hz}, 2 \mathrm{H}), 7.88(\mathrm{~d}, J=8.4 \mathrm{~Hz}, 2 \mathrm{H}), 7.74(\mathrm{~d}, J=7.4 \mathrm{~Hz}$, 
2H), $7.55-7.44(\mathrm{~m}, 3 \mathrm{H}), 7.37$ (dt, $J=26.4,7.4 \mathrm{~Hz}, 3 \mathrm{H}), 7.03-6.98(\mathrm{~m}, 1 \mathrm{H}), 6.96(\mathrm{~s}, 1 \mathrm{H}), 6.85$ $(\mathrm{d}, J=2.6 \mathrm{~Hz}, 1 \mathrm{H}), 3.91(\mathrm{~s}, 3 \mathrm{H}), 3.84(\mathrm{~s}, 4 \mathrm{H}), 3.06-2.94(\mathrm{~m}, 5 \mathrm{H}), 1.23(\mathrm{t}, J=8.2 \mathrm{~Hz}, 8 \mathrm{H}) .{ }^{19} \mathrm{~F}$ NMR (471 MHz, $\left.\mathrm{CD}_{2} \mathrm{Cl}_{2}\right) \delta-133.85(\mathrm{dd}, J=64.9,32.2 \mathrm{~Hz}) .{ }^{11} \mathrm{~B} \mathrm{NMR}\left(161 \mathrm{MHz}, \mathrm{CD}_{2} \mathrm{Cl}_{2}\right) \delta 1.18$ (t, $J=32.5 \mathrm{~Hz})$.

Compound 18. A RBF was charged with pyrrole b (78.1 mg, $0.284 \mathrm{mmol}, 1.0$ eq.), sodium nitrite (19.8 $\mathrm{mg}, 0.287 \mathrm{mmol}, 1.0 \mathrm{eq}$.), and acetic acid $(2.9 \mathrm{~mL})$. The reaction mixture was stirred at room temperature for $20 \mathrm{~min}$. Pyrrole $\mathbf{g}(99.5 \mathrm{mg}, 0.286 \mathrm{mmol}, 1.0$ eq.) and acetic anhydride $(1.2 \mathrm{~mL})$ were added. The reaction mixture was stirred for $20 \mathrm{~min}$ at room temperature, then $30 \mathrm{~min}$ at 80 ${ }^{\circ} \mathrm{C}$. The reaction mixture was cooled, diluted with a cold saturated solution of sodium bicarbonate, and filtered to isolate the heterodimer as a dark solid. The resulting solid was purified by alumina column chromatography ( $3 \%$ ethyl acetate/toluene) to yield the product $(71.0 \mathrm{mg}, 0.112 \mathrm{mmol}$, $39 \%$ yield). ${ }^{1} \mathrm{H}$ NMR (500 MHz, $\left.\mathrm{CD}_{2} \mathrm{Cl}_{2}\right) \delta 8.20(\mathrm{~d}, J=8.6 \mathrm{~Hz}, 1 \mathrm{H}), 8.06(\mathrm{~d}, J=7.7 \mathrm{~Hz}, 2 \mathrm{H}), 7.76$ (d, $J=7.5 \mathrm{~Hz}, 2 \mathrm{H}), 7.71(\mathrm{~d}, J=8.2 \mathrm{~Hz}, 2 \mathrm{H}), 7.48(\mathrm{t}, J=7.5 \mathrm{~Hz}, 2 \mathrm{H}), 7.41(\mathrm{t}, J=7.6 \mathrm{~Hz}, 3 \mathrm{H}), 7.36$ $(\mathrm{t}, J=7.7 \mathrm{~Hz}, 2 \mathrm{H}), 7.26(\mathrm{t}, J=7.4 \mathrm{~Hz}, 1 \mathrm{H}), 7.05-7.01(\mathrm{~m}, 1 \mathrm{H}), 6.97(\mathrm{~s}, 1 \mathrm{H}), 6.89(\mathrm{~d}, J=2.5 \mathrm{~Hz}$, 1H), $3.92(\mathrm{~s}, 3 \mathrm{H}), 3.31(\mathrm{~s}, 2 \mathrm{H}), 3.07(\mathrm{~d}, J=6.1 \mathrm{~Hz}, 2 \mathrm{H}), 3.03(\mathrm{~d}, J=6.1 \mathrm{~Hz}, 2 \mathrm{H}), 1.49(\mathrm{~s}, 9 \mathrm{H}) .{ }^{13} \mathrm{C}$ NMR $\left(126 \mathrm{MHz}, \mathrm{CD}_{2} \mathrm{Cl}_{2}\right) \delta 169.72,164.90,163.32,156.18,146.51,145.71,142.01,141.01$, 139.23, 138.12, 136.36, 135.07, 134.63, 132.05, 130.22, 130.06, 129.81, 129.64, 129.53, 128.81, $127.59,126.66,124.39,115.76,115.65,109.22,82.31,57.45,38.85,31.43,29.97,24.61$.

r-CRaB-NOD. Compound 18 (31.5 mg, $0.050 \mathrm{mmol}, 1.0$ eq.) was suspended in dichloroethane $(1 \mathrm{~mL})$ and triethylamine $(0.12 \mathrm{~mL})$ and $\mathrm{BF}_{3} \mathrm{OEt}_{2}(0.12 \mathrm{~mL})$ were added. The reaction mixture was stirred for $20 \mathrm{~min}$ at room temperature and $30 \mathrm{~min}$ at $80^{\circ} \mathrm{C}$. The reaction mixture was then cooled, diluted with water, and extracted with dichloromethane. The organic layer was washed with saturated sodium bicarbonate, dried over sodium sulfate, and concentrated. The resulting solid was purified by silica column chromatography ( $3 \%$ ethyl acetate/toluene) to yield the product (18.2 $\mathrm{mg}, 0.031 \mathrm{mmol}, 62 \%$ yield). ${ }^{1} \mathrm{H}$ NMR $\left(500 \mathrm{MHz}\right.$, Acetone- $\left.d_{6}\right) \delta 8.68(\mathrm{~d}, J=8.7 \mathrm{~Hz}, 1 \mathrm{H}), 8.33-$ $8.26(\mathrm{~m}, 2 \mathrm{H}), 8.26-8.22(\mathrm{~m}, 2 \mathrm{H}), 7.85-7.77(\mathrm{~m}, 2 \mathrm{H}), 7.59-7.50(\mathrm{~m}, 3 \mathrm{H}), 7.48-7.35(\mathrm{~m}, 4 \mathrm{H})$, $7.00(\mathrm{~d}, J=8.1 \mathrm{~Hz}, 2 \mathrm{H}), 6.82-6.76(\mathrm{~m}, 2 \mathrm{H}), 3.93(\mathrm{~s}, 3 \mathrm{H}), 3.02-2.92(\mathrm{~m}, 7 \mathrm{H}) .{ }^{13} \mathrm{C}$ NMR $(126$ MHz, Acetone- $\left.d_{6}\right) \delta 162.70,158.60,153.95,150.74,146.59,145.24,144.94,142.00,136.36$, $133.48,133.44,133.40,133.36,131.31,131.23,129.85,129.74,129.27,128.98,128.88,121.46$, 
$119.60,119.37,115.13,113.60,112.78,55.90,31.12,30.59,22.31 .{ }^{19} \mathrm{~F}$ NMR (471 MHz, Acetone$\left.d_{6}\right) \delta-133.83(\mathrm{dd}, J=66.5,33.2 \mathrm{~Hz}) .{ }^{11} \mathrm{~B}$ NMR $\left(161 \mathrm{MHz}\right.$, Acetone- $\left.d_{6}\right) \delta 1.51(\mathrm{t}, J=33.3 \mathrm{~Hz})$.

CRaB-photoNOD. r-CRaB-NOD (16.4 mg, $0.028 \mathrm{mmol}, 1.0$ eq.) was dissolved in acetic acid (1 $\mathrm{mL})$, anhydrous THF $(2 \mathrm{~mL})$ and dichloromethane $(1 \mathrm{~mL})$ and stirred at $0{ }^{\circ} \mathrm{C}$. Sodium nitrite $(9.7$ $\mathrm{mg}, 0.14 \mathrm{mmol}, 5.0$ eq.) was added and the reaction mixture was stirred for $1 \mathrm{~h}$. The reaction mixture was diluted with a saturated solution of sodium bicarbonate and extracted with ethyl acetate. The organic layer was dried over sodium sulfate, filtered through a cotton plug, and concentrated to a green film (8.24 mg, $0.013 \mathrm{mmol}, 48 \%$ yield). ${ }^{1} \mathrm{H}$ NMR $\left(500 \mathrm{MHz}, \mathrm{CDCl}_{3}\right) \delta$ $8.75(\mathrm{~d}, J=9.0 \mathrm{~Hz}, 1 \mathrm{H}), 8.21-8.15(\mathrm{~m}, 2 \mathrm{H}), 8.10-8.04$ (m, 2H), $7.77-7.73(\mathrm{~m}, 2 \mathrm{H}), 7.73-$ $7.68(\mathrm{~m}, 2 \mathrm{H}), 7.51(\mathrm{dd}, J=8.3,6.6 \mathrm{~Hz}, 2 \mathrm{H}), 7.49-7.44(\mathrm{~m}, 1 \mathrm{H}), 7.43-7.38(\mathrm{~m}, 2 \mathrm{H}), 7.37-7.33$ (m, 1H), $6.98(\mathrm{~d}, J=8.0 \mathrm{~Hz}, 2 \mathrm{H}), 6.85(\mathrm{~d}, J=2.6 \mathrm{~Hz}, 1 \mathrm{H}), 3.91(\mathrm{~s}, 3 \mathrm{H}), 3.52(\mathrm{~d}, J=0.7 \mathrm{~Hz}, 3 \mathrm{H})$, $3.02-2.93(\mathrm{~m}, 3 \mathrm{H}) .{ }^{13} \mathrm{C}$ NMR $\left(126 \mathrm{MHz}, \mathrm{CDCl}_{3}\right) \delta 163.61,157.59,151.93,147.69,145.91$, 144.04, 142.90, 139.64, 139.54, 133.60, 133.13, 132.97, 131.68, 130.66, 130.63, 130.59, 129.00, $128.70,128.63,128.59,128.39,119.68,118.57,116.76,114.83,113.66,55.75,31.01,30.59$, 22.06. ${ }^{19} \mathrm{~F}$ NMR $\left(471 \mathrm{MHz}, \mathrm{CDCl}_{3}\right) \delta-133.75(\mathrm{dd}, J=64.9,32.5 \mathrm{~Hz}) .{ }^{11} \mathrm{~B} \mathrm{NMR}\left(161 \mathrm{MHz}, \mathrm{CDCl}_{3}\right)$ $\delta 1.23(\mathrm{t}, J=32.6 \mathrm{~Hz})$.

Compound 19. A RBF was charged with pyrrole b ( $156 \mathrm{mg}, 0.567 \mathrm{mmol}, 1.0$ eq.), sodium nitrite (39.2 $\mathrm{mg}, 0.568 \mathrm{mmol}, 1.0 \mathrm{eq}$.), and acetic acid $(6.5 \mathrm{~mL})$. The reaction mixture was stirred at room temperature fore $20 \mathrm{~min}$. Pyrrole $\mathbf{h}$ (195 mg, $0.568 \mathrm{mmol}, 1.0$ eq.) and acetic anhydride (2.6 mL) were added. The reaction mixture was stirred for $20 \mathrm{~min}$ at room temperature, then $30 \mathrm{~min}$ at 80 ${ }^{\circ} \mathrm{C}$. The reaction mixture was cooled, diluted with a cold saturated solution of sodium bicarbonate, and filtered to isolate the heterodimer as a dark solid. The resulting solid was suspended in dichloroethane $(6 \mathrm{~mL})$ and triethylamine $(680 \mu \mathrm{L})$ and $\mathrm{BF}_{3} \mathrm{OEt}_{2}(680 \mu \mathrm{L})$ were added. The reaction mixture was stirred for $20 \mathrm{~min}$ at room temperature and $30 \mathrm{~min}$ at $80^{\circ} \mathrm{C}$. The reaction mixture was then cooled, diluted with water, and extracted with ethyl acetate. The organic layer was washed with saturated sodium bicarbonate, dried over sodium sulfate, and concentrated. The resulting solid was purified by alumina column chromatography ( $50 \%$ dichloromethane/hexanes and then $75 \%$ dichloromethane/hexanes) to yield the product (132.5 mg, $0.195 \mathrm{mmol}, 30 \%$ yield over 2 steps). ${ }^{1} \mathrm{H}$ NMR (500 MHz, $\left.\mathrm{CDCl}_{3}\right) \delta 8.75(\mathrm{~d}, J=9.0 \mathrm{~Hz}, 1 \mathrm{H}), 8.08-8.01(\mathrm{~m}, 2 \mathrm{H}), 8.00-7.96(\mathrm{~m}, 2 \mathrm{H})$, $7.75-7.70(\mathrm{~m}, 2 \mathrm{H}), 7.53-7.43(\mathrm{~m}, 3 \mathrm{H}), 7.42-7.30(\mathrm{~m}, 3 \mathrm{H}), 7.03-6.97(\mathrm{~m}, 1 \mathrm{H}), 6.87-6.82$ 
(m, 2H), $6.29-6.14(\mathrm{~m}, 1 \mathrm{H}), 5.51(\mathrm{dp}, J=17.3,1.4 \mathrm{~Hz}, 1 \mathrm{H}), 5.34(\mathrm{dt}, J=10.4,1.3 \mathrm{~Hz}, 1 \mathrm{H}), 4.67$ $(\mathrm{dq}, J=6.1,1.3 \mathrm{~Hz}, 2 \mathrm{H}), 3.93-3.87(\mathrm{~m}, 3 \mathrm{H}), 2.95(\mathrm{dp}, J=10.8,6.0,5.4 \mathrm{~Hz}, 4 \mathrm{H}) .{ }^{13} \mathrm{C}$ NMR $(126$ $\left.\mathrm{MHz}, \mathrm{CDCl}_{3}\right) \delta 163.99,158.68,151.96,148.98,148.07,146.23,143.44,139.83,138.83,134.10$, 133.36, 133.17, 133.04, 131.44, 130.55, 130.37, 129.66, 129.63, 129.58, 129.09, 128.90, 128.59, 128.35, 119.35, 118.90, 116.42, 114.97, 113.67, 74.66, 55.77, 30.45, 22.02. ${ }^{19} \mathrm{~F}$ NMR (471 MHz, $\left.\mathrm{CDCl}_{3}\right) \delta-133.66(\mathrm{dd}, J=64.8,31.9 \mathrm{~Hz}) .{ }^{11} \mathrm{~B} \mathrm{NMR}\left(161 \mathrm{MHz}, \mathrm{CDCl}_{3}\right) \delta 1.10(\mathrm{t}, J=32.4 \mathrm{~Hz})$.

t-CRaB-OMe-APC. A two-neck RBF was charged with compound 19 (34 mg, 0.050 mmol, 1.0 eq.), 1,3-dimethylbarbituric acid (10.2 mg, $0.065 \mathrm{mmol}, 1.3$ eq.) and $\mathrm{Pd}\left(\mathrm{PPh}_{3}\right)_{4}(11.1 \mathrm{mg}, 0.0096$ mmol, 0.2 eq.). The solids were dried under vacuum and flushed with nitrogen. Anhydrous DMF $(1 \mathrm{~mL})$ was added and the reaction mixture was stirred for $1 \mathrm{~h}$. The reaction mixture was poured into brine and extracted with ethyl acetate. The organic layer was dried, concentrated, and purified by silica column chromatography $(0.1 \% \mathrm{AcOH}$ in dichloromethane) to yield the product (26.1 $\mathrm{mg}$, $0.041 \mathrm{mmol}, 82 \%$ yield). ${ }^{1} \mathrm{H}$ NMR $\left(500 \mathrm{MHz}, \mathrm{DMSO}-d_{6}\right) \delta 8.56(\mathrm{~d}, J=8.9 \mathrm{~Hz}, 1 \mathrm{H}), 8.13(\mathrm{~d}, J=$ $9.8 \mathrm{~Hz}, 4 \mathrm{H}), 7.78(\mathrm{~d}, J=7.6 \mathrm{~Hz}, 2 \mathrm{H}), 7.58(\mathrm{t}, J=7.5 \mathrm{~Hz}, 2 \mathrm{H}), 7.51$ (t, $J=7.4 \mathrm{~Hz}, 1 \mathrm{H}), 7.43$ (dd, $J=13.0,5.5 \mathrm{~Hz}, 3 \mathrm{H}), 7.37(\mathrm{t}, J=7.3 \mathrm{~Hz}, 1 \mathrm{H}), 7.13(\mathrm{~d}, J=9.7 \mathrm{~Hz}, 2 \mathrm{H}), 3.92(\mathrm{~s}, 3 \mathrm{H}), 2.98(\mathrm{tt}, J=$ 13.7, 8.3 Hz, 4H). ${ }^{13} \mathrm{C}$ NMR (126 MHz, DMSO- $\left.d_{6}\right) \delta 163.69,156.78,150.70,149.29,146.90$, $146.68,142.82$, 138.45, 138.27, 134.22, 132.32, 131.82, 130.82, 130.22, 129.20, 129.10, 128.78, $128.66,128.53,128.35,124.40,122.34,118.48,117.53,114.84,114.01,55.93,29.39,21.15 .{ }^{19} \mathrm{~F}$ NMR (471 MHz, DMSO- $\left.d_{6}\right) \delta-132.02(\mathrm{dd}, J=66.3,31.4 \mathrm{~Hz}) .{ }^{11} \mathrm{~B}$ NMR $\left(161 \mathrm{MHz}, \mathrm{DMSO}-d_{6}\right)$ $\delta 1.10(\mathrm{t}, J=32.9 \mathrm{~Hz})$.

CRaB-OMe-APC. A $25 \mathrm{~mL}$ RBF was charged with t-CRaB-OMe-APC (100 mg, $0.157 \mathrm{mmol}$, 1.0 eq.), 2-picolinic acid (77.5 mg, $0.630 \mathrm{mmol}, 4.0$ eq.), 4-(dinmethylamino)pyridine (3.4 mg, $0.0278 \mathrm{mmol}, 0.18$ eq.), EDC-HCl (46.1 mg, $0.241 \mathrm{mmol}, 1.5$ eq.) and anhydrous DMF (7.8 mL). The reaction mixture was stirred at room temperature for $1 \mathrm{~h}$. The reaction was diluted with brine and extracted with ethyl acetate. The organic layer was washed with brine and $1 \% \mathrm{HCl}$, dried over sodium sulfate, and purified by column chromatography (gradient, $30 \%$ to $60 \%$ to $100 \%$ ethyl acetate/hexanes with $0.1 \% \mathrm{AcOH})$ to provide the product $\left(34.0 \mathrm{mg}, 0.0457 \mathrm{mmol}, 29 \%\right.$ yield). ${ }^{1} \mathrm{H}$ NMR $\left(500 \mathrm{MHz}, \mathrm{CDCl}_{3}\right) \delta 8.92(\mathrm{ddd}, J=4.8,1.8,0.9 \mathrm{~Hz}, 1 \mathrm{H}), 8.77(\mathrm{~d}, J=9.1 \mathrm{~Hz}, 1 \mathrm{H}), 8.40-$ $8.35(\mathrm{~m}, 1 \mathrm{H}), 8.09-8.02(\mathrm{~m}, 4 \mathrm{H}), 7.97(\mathrm{td}, J=7.7,1.8 \mathrm{~Hz}, 1 \mathrm{H}), 7.76-7.71(\mathrm{~m}, 2 \mathrm{H}), 7.61$ (ddd, $J=7.8,4.7,1.2 \mathrm{~Hz}, 1 \mathrm{H}), 7.54-7.49(\mathrm{~m}, 2 \mathrm{H}), 7.49-7.43(\mathrm{~m}, 1 \mathrm{H}), 7.39(\mathrm{dd}, J=8.3,6.5 \mathrm{~Hz}, 2 \mathrm{H})$, 
$7.36-7.31(\mathrm{~m}, 1 \mathrm{H}), 7.03(\mathrm{dd}, J=9.1,2.7 \mathrm{~Hz}, 1 \mathrm{H}), 6.88(\mathrm{~s}, 1 \mathrm{H}), 6.85(\mathrm{~d}, J=2.7 \mathrm{~Hz}, 1 \mathrm{H}), 3.92(\mathrm{~s}$, 3H), $3.04-2.90(\mathrm{~m}, 4 \mathrm{H}) .{ }^{13} \mathrm{C} \mathrm{NMR}\left(126 \mathrm{MHz}, \mathrm{CDCl}_{3}\right) \delta 164.25,161.69,159.36,150.62,148.42$, $148.14,146.50,146.41,144.55,143.37,140.14,138.63,137.43,134.43,133.78,133.12,132.97$, $131.41,130.60,129.47,129.21,128.94,128.86,128.64,128.62,128.42,127.93,126.47,119.29$, 116.51, 115.15, 113.77, 55.85, 30.50, 22.12. $\left.{ }^{19} \mathrm{~F} \mathrm{NMR} \mathrm{(471} \mathrm{MHz,} \mathrm{CDCl}_{3}\right) \delta-133.62(\mathrm{dd}, J=65.0$, $32.1 \mathrm{~Hz}) .{ }^{11} \mathrm{~B} \mathrm{NMR}\left(161 \mathrm{MHz}, \mathrm{CDCl}_{3}\right) \delta 1.10(\mathrm{t}, J=32.4 \mathrm{~Hz})$.

Compound 20 A RBF was charged with pyrrole a (91.8 mg, $0.368 \mathrm{mmol}, 1.0$ eq.), sodium nitrite (24.7 mg, $0.358 \mathrm{mmol}, 1.0$ eq.), and acetic acid (3.6 mL). The reaction mixture was stirred at room temperature fore $20 \mathrm{~min}$. Pyrrole h (125 mg, $0.363 \mathrm{mmol}, 1.0$ eq.) and acetic anhydride (1.4 mL) were added. The reaction mixture was stirred for $20 \mathrm{~min}$ at room temperature, then $30 \mathrm{~min}$ at 80 ${ }^{\circ} \mathrm{C}$. The reaction mixture was cooled, diluted with a cold saturated solution of sodium bicarbonate, and filtered to isolate the heterodimer as a dark solid. The solid was suspended in dichloroethane $(7 \mathrm{~mL})$ and triethylamine $(850 \mu \mathrm{L})$ and $\mathrm{BF}_{3} \mathrm{OEt}_{2}(850 \mu \mathrm{L})$ were added. The reaction mixture was stirred for $20 \mathrm{~min}$ at room temperature and $30 \mathrm{~min}$ at $80^{\circ} \mathrm{C}$. The reaction mixture was then cooled, diluted with water, and extracted with dichloromethane. The organic layer was washed with saturated sodium bicarbonate, dried over sodium sulfate, and concentrated. The resulting solid was purified by alumina column chromatography ( $50 \%$ dichloromethane/hexanes) to yield the product (53.5 mg, $0.0789 \mathrm{mmol}, 21 \%$ yield over 2 steps). ${ }^{1} \mathrm{H}$ NMR $\left(500 \mathrm{MHz}, \mathrm{CDCl}_{3}\right) \delta 8.21-8.12(\mathrm{~m}$, 2H), $8.09-8.05(\mathrm{~m}, 2 \mathrm{H}), 8.05-8.02(\mathrm{~m}, 2 \mathrm{H}), 7.97(\mathrm{~s}, 2 \mathrm{H}), 7.51-7.37(\mathrm{~m}, 7 \mathrm{H}), 7.16(\mathrm{~s}, 1 \mathrm{H}), 7.09$ $-7.00(\mathrm{~m}, 2 \mathrm{H}), 6.90(\mathrm{~s}, 1 \mathrm{H}), 6.28-6.11(\mathrm{~m}, 1 \mathrm{H}), 5.48(\mathrm{dt}, J=17.0,1.5 \mathrm{~Hz}, 1 \mathrm{H}), 5.33(\mathrm{dd}, J=$ $10.4,1.5 \mathrm{~Hz}, 1 \mathrm{H}), 4.64(\mathrm{dt}, J=6.0,1.3 \mathrm{~Hz}, 2 \mathrm{H}), 3.91(\mathrm{~s}, 3 \mathrm{H}) .{ }^{13} \mathrm{C} \mathrm{NMR}\left(126 \mathrm{MHz}, \mathrm{CDCl}_{3}\right) \delta$ $163.17,162.07,152.57,152.32$, 147.12, 145.74, 144.23, 141.91, 133.07, 132.69, 132.51, 131.94, $130.06,129.83,129.79,129.71,129.62,129.33$, 129.29, 128.81, 128.75, 123.28, 120.28, 119.03, 117.73, 114.72, 74.72, 55.72. ${ }^{19} \mathrm{~F} \operatorname{NMR}\left(471 \mathrm{MHz}, \mathrm{CDCl}_{3}\right) \delta-131.70(\mathrm{dd}, J=63.5,31.7 \mathrm{~Hz}) .{ }^{11} \mathrm{~B}$ $\operatorname{NMR}\left(161 \mathrm{MHz}, \mathrm{CDCl}_{3}\right) \delta 0.95(\mathrm{t}, J=31.7 \mathrm{~Hz})$.

t-OMe-APC. A two-neck RBF was charged with compound 20 (42.8 mg, 0.0656 mmol, 1.0 eq.), 1,3-dimethylbarbituric acid (12.8 mg, $0.082 \mathrm{mmol}, 1.3$ eq.) and $\mathrm{Pd}\left(\mathrm{PPh}_{3}\right)_{4}(15.2 \mathrm{mg}, 0.0131 \mathrm{mmol}$, 0.2 eq.). The solids were dried under vacuum and flushed with nitrogen. Anhydrous DMF (1 mL) was added and the reaction mixture was stirred for $1 \mathrm{~h}$. The reaction mixture was poured into brine and extracted with ethyl acetate. The organic layer was dried, concentrated, and purified by silica 
column chromatography ( $1 \%$ methanol/dichloromethane) to yield the product $(29.8 \mathrm{mg}, 0.0467$ mmol, 71\% yield). ${ }^{1} \mathrm{H}$ NMR (500 MHz, DMSO- $\left.d_{6}\right) \delta 8.26-8.21(\mathrm{~m}, 2 \mathrm{H}), 8.21-8.13(\mathrm{~m}, 6 \mathrm{H})$, $7.71(\mathrm{~s}, 1 \mathrm{H}), 7.64(\mathrm{~s}, 1 \mathrm{H}), 7.58-7.44(\mathrm{~m}, 7 \mathrm{H}), 7.20-7.14(\mathrm{~m}, 2 \mathrm{H}), 3.91(\mathrm{~s}, 3 \mathrm{H}) .{ }^{19} \mathrm{~F}$ NMR $(471$ MHz, DMSO- $\left.d_{6}\right) \delta-130.15(\mathrm{dd}, J=65.8,32.4 \mathrm{~Hz}) .{ }^{11} \mathrm{~B}$ NMR $\left(161 \mathrm{MHz}, \mathrm{DMSO}-d_{6}\right) \delta 0.97(\mathrm{t}, J=$ $32.8 \mathrm{~Hz})$.

OMe-APC. $25 \mathrm{~mL}$ RBF was charged with t-OMe-APC (22.9 mg, $0.037 \mathrm{mmol}, 1.0$ eq.), 2-picolinic acid (18.4 mg, $0.150 \mathrm{mmol}, 4.0$ eq.), 4-(dinmethylamino)pyridine (0.46 mg, $0.0307 \mathrm{mmol}, 0.1$ eq.), EDC-HCl (10.8 mg, $0.056 \mathrm{mmol}, 1.5$ eq.) and anhydrous DMF (2 mL). The reaction mixture was stirred at room temperature for $4 \mathrm{~h}$. The reaction was diluted with brine and extracted with ethyl acetate. The organic layer was dried over sodium sulfate, and purified by column chromatography ( $10 \%$ ethyl acetate/toluene) to yield the product $(25.7 \mathrm{mg}, .0358 \mathrm{mmol}, 97 \%$ yield). ${ }^{1} \mathrm{H}$ NMR (499 MHz, $\left.\mathrm{CDCl}_{3}\right) \delta 8.92(\mathrm{dt}, J=4.4,1.5 \mathrm{~Hz}, 1 \mathrm{H}), 8.36(\mathrm{dt}, J=7.8,1.1 \mathrm{~Hz}, 1 \mathrm{H})$, $8.20(\mathrm{~d}, J=9.0 \mathrm{~Hz}, 2 \mathrm{H}), 8.11-8.01(\mathrm{~m}, 6 \mathrm{H}), 8.00-7.94(\mathrm{~m}, 1 \mathrm{H}), 7.62$ (ddd, $J=7.7,4.7,1.2 \mathrm{~Hz}$, 1H), $7.51-7.38$ (m, 7H), 7.20 (s, 1H), $7.06(\mathrm{dd}, J=9.7,2.7 \mathrm{~Hz}, 2 \mathrm{H}), 6.94$ (s, 1H), 3.91 (d, $J=6.1$ $\mathrm{Hz}, 4 \mathrm{H}) .{ }^{13} \mathrm{C}$ NMR $\left(126 \mathrm{MHz}, \mathrm{CDCl}_{3}\right) \delta 163.41,162.85,161.61,151.22,150.62,147.50,146.38$, 146.14, 145.07, 144.04, 141.55, 137.45, 132.80, 132.74, 132.33, 131.82, 130.19, 129.67, 129.57, 129.33, 129.25, 129.06, 128.83, 128.77, 127.98, 126.49, 123.06, 117.69, 117.68, 114.83, 55.75. ${ }^{19} \mathrm{~F}$ NMR $\left(471 \mathrm{MHz}, \mathrm{CDCl}_{3}\right) \delta-131.50(\mathrm{dd}, J=63.6,31.7 \mathrm{~Hz}) .{ }^{11} \mathrm{~B} \mathrm{NMR}\left(161 \mathrm{MHz}, \mathrm{CDCl}_{3}\right) \delta$ $0.96(\mathrm{t}, J=31.7 \mathrm{~Hz})$. 


\section{Supplementary Figures and Tables}

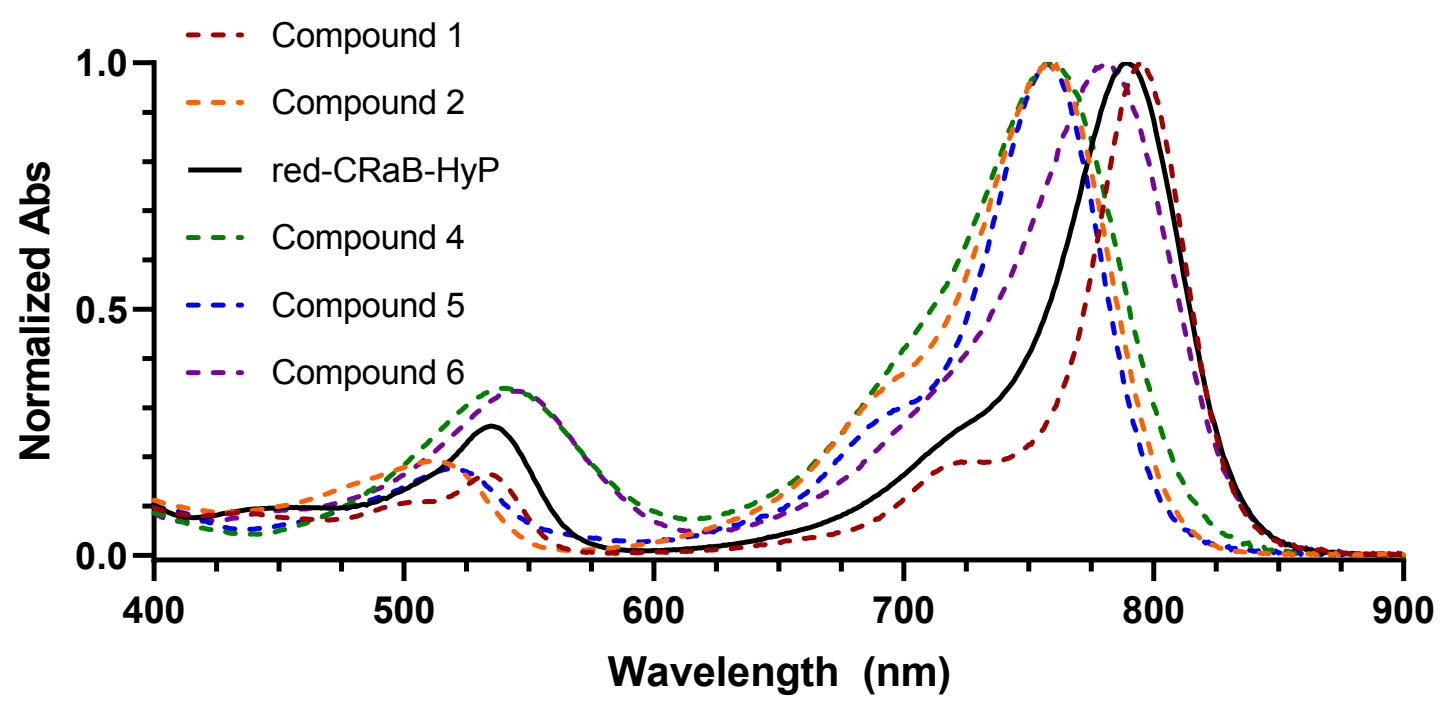

Figure S1. Normalized absorbance spectra of red-HyP-1 analogues in $\mathrm{CHCl}_{3}$.

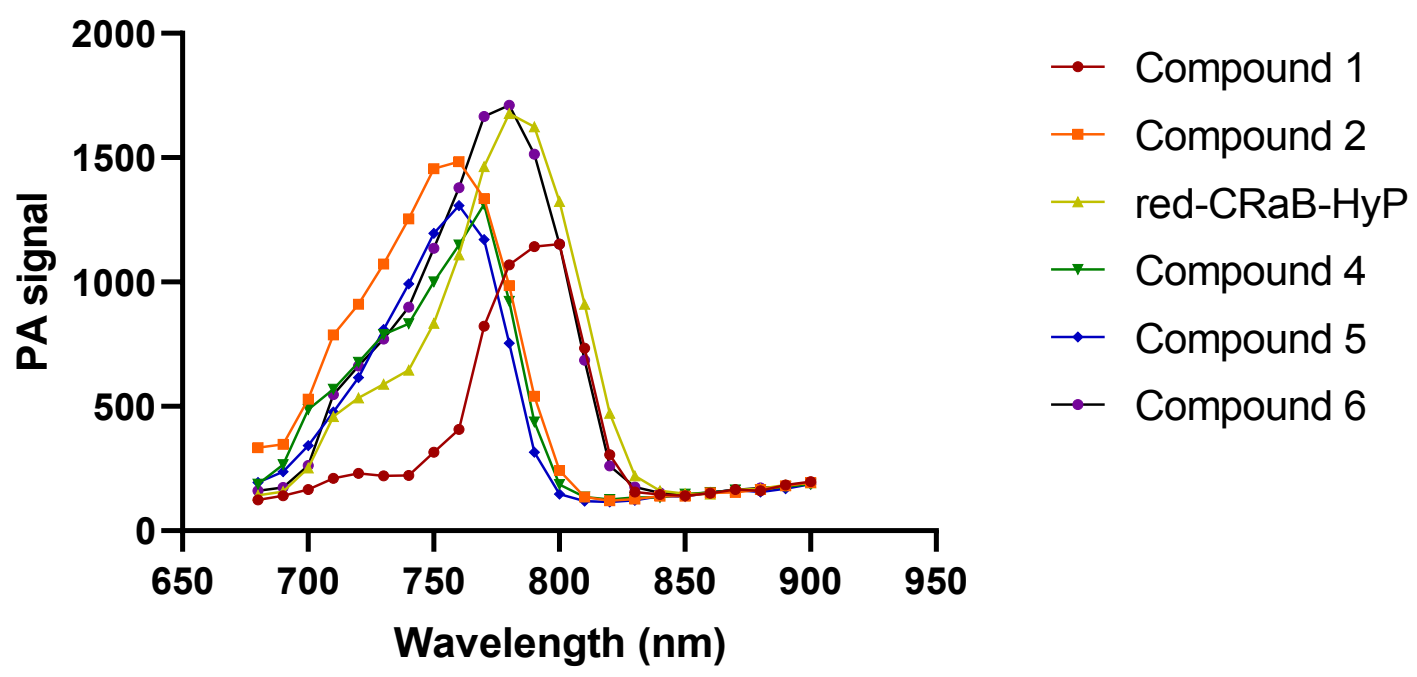

Figure S2. PA spectra for red-HyP-1 analogues with various conformational restrictions. Spectra were acquired for $10 \mu \mathrm{M}$ solutions in $\mathrm{CHCl}_{3}$, in tissue-mimicking phantoms. 
Table S1. PA wavelengths for the red-HyP analogues (main text compounds 1-6) in chloroform, as shown above in Figure S2.

\begin{tabular}{|c|c|c|}
\hline Compound & $\lambda$ abs $(\mathrm{nm})$ & $\lambda P A(\mathrm{~nm})$ \\
\hline red-HyP-1 & 760 & 770 \\
\hline 1 & 796 & 790 \\
\hline 2 & 759 & 760 \\
\hline 3 & 789 & 780 \\
\hline 4 & 757 & 770 \\
\hline 5 & 759 & 760 \\
\hline 6 & 782 & 780 \\
\hline
\end{tabular}

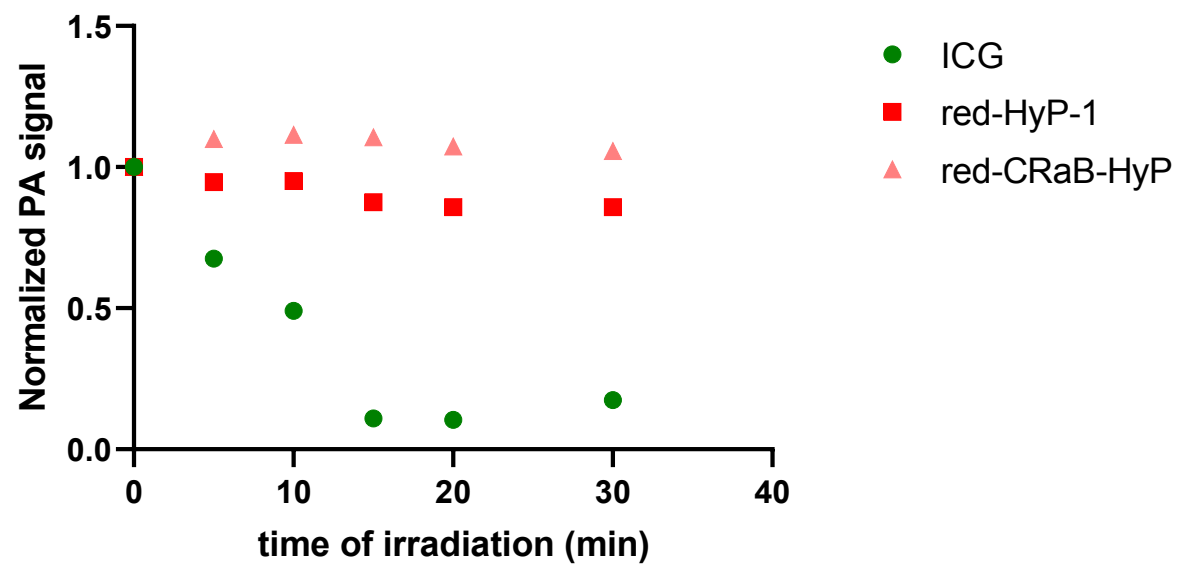

Figure S3. Photostability of red-CRaB-HyP relative to ICG and red-HyP-1. Photostability was assessed in $\mathrm{CHCl}_{3}$ in tissue-mimicking phantoms.

Table S2. Absorbance wavelengths for the red-HyP analogues (main text compounds 1-6) in 1 $\mathrm{mL}$ of 1:1 acetonitrile/PBS, and shift in wavelengths upon protonation with $20 \mu \mathrm{L} \mathrm{HCl}$.

\begin{tabular}{|c|c|c|c|}
\hline Compound & $\lambda(\mathrm{nm})$ at $\mathrm{pH} 7.4$ & $\lambda(\mathrm{nm})$ upon protonation & $\Delta \lambda$ \\
\hline red-HyP-1 & 760 & 665 & 95 \\
\hline 1 & 792 & 713 & 79 \\
\hline 2 & 751 & 695 & 56 \\
\hline 3 (red-CRaB-HyP) & 794 & 679 & 115 \\
\hline 4 & 761 & 667 & 94 \\
\hline 5 & 751 & 693 & 58 \\
\hline 6 & 780 & 683 & 97 \\
\hline
\end{tabular}



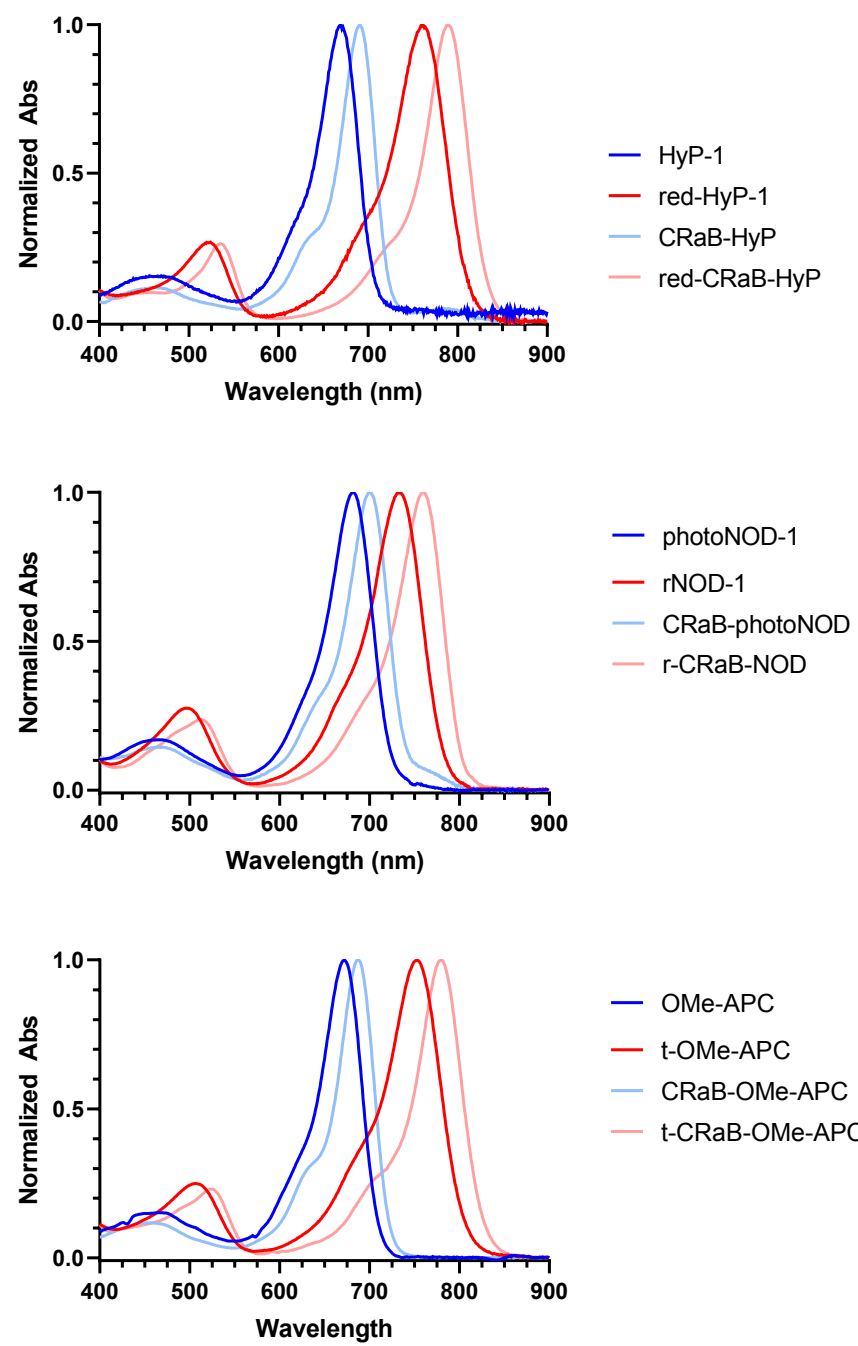

- OMe-APC

- $\mathrm{t}$-OMe-APC

- CRaB-OMe-APC

- t-CRaB-OMe-APC

Figure S4. Normalized absorbance spectra of probe/product pairs in $\mathrm{CHCl}_{3}$. Note t-OMe-APC and $\mathrm{t}-\mathrm{CRaB}-\mathrm{OMe}-\mathrm{APC}$ spectra were obtained in the presence of $\mathrm{Et}_{3} \mathrm{~N}$.

Table S3. PA wavelengths $\lambda_{\text {red }}$ and $\lambda_{\text {blue }}$ for each probe-product pair in chloroform and in 1:1 acetonitrile/PBS mixtures, as shown in Figure S5.

\begin{tabular}{|c|c|c|c|c|c|}
\hline \multirow{2}{*}{ Probe } & \multirow{2}{*}{ Product } & \multicolumn{2}{|c|}{$\mathrm{CHCl}_{3}$} & \multicolumn{2}{c|}{$1: 1 \mathrm{MeCN} / \mathrm{PBS}$} \\
\cline { 3 - 6 } & & $\lambda_{\text {blue }}$ & $\lambda_{\text {red }}$ & $\lambda_{\text {blue }}$ & $\lambda_{\text {red }}$ \\
\hline HyP-1 & red-HyP-1 & 680 & 770 & 680 & 770 \\
\hline photoNOD-1 & rNOD-1 & 680 & 730 & 680 & 740 \\
\hline OMe-APC & t-OMe-APC & 680 & 750 & 680 & 750 \\
\hline CRaB-HyP & red-CRaB-HyP & 690 & 780 & 680 & 790 \\
\hline CRaB-photoNOD & r-CRaB-NOD & 700 & 760 & 680 & 770 \\
\hline CRaB-OMe-APC / & t-CRaB-OMe-APC & 680 & 780 & 680 & 780 \\
\hline
\end{tabular}


Table S4. $\Delta \lambda_{\text {abs }}$ for each probe-product pair in chloroform.

\begin{tabular}{|l|c|c|}
\hline & Unrestricted $\lambda_{\text {abs }}(\mathrm{nm})$ & $\mathrm{CRaB} \lambda_{\text {abs }}(\mathrm{nm})$ \\
\hline redHyP / HyP & 90 & 98 \\
\hline rNOD / photoNOD & 52 & 61 \\
\hline tOMe-APC / OMe-APC & 81 & 93 \\
\hline
\end{tabular}
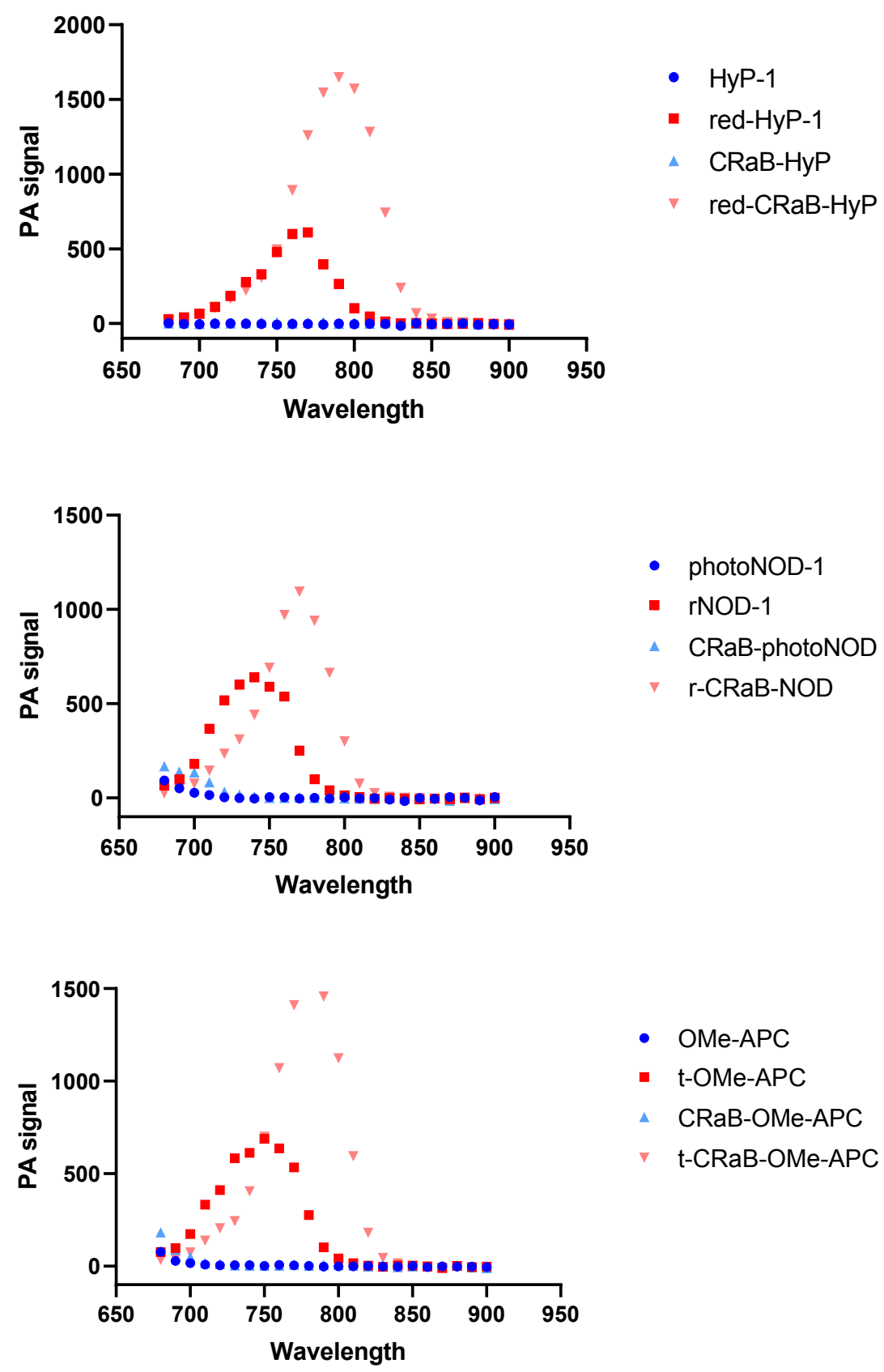

Figure S5. PA spectra of HyP, photoNOD, and APC compounds in 1:1 acetonitrile/PBS mixtures. 


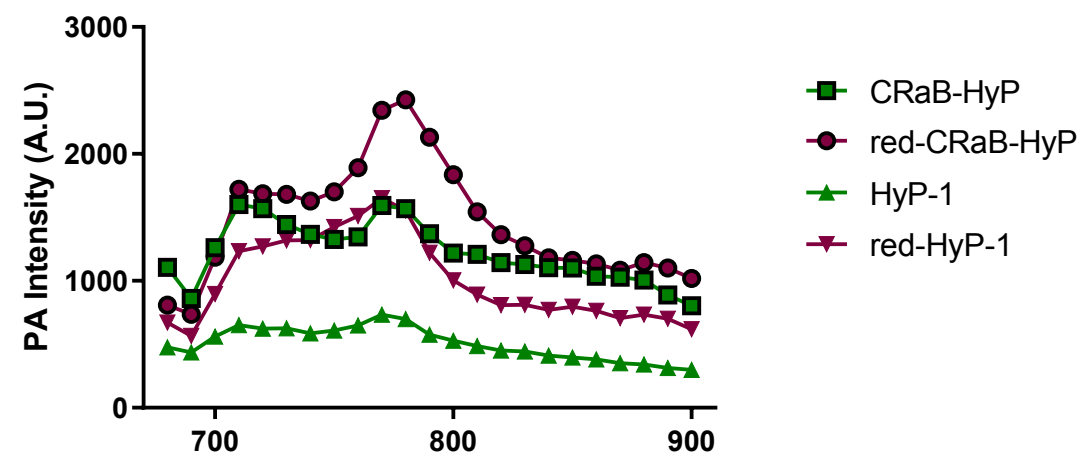

Figure S6. In vivo PA spectra of HyP-1, red-HyP-1, CRaB-HyP, and red-CRaB-HyP in subcutaneous space, $1 \mathrm{~h}$ post-injection. $710 \mathrm{~nm}$ and $770 \mathrm{~nm}$ were selected as $\lambda_{\text {blue }}$ and $\lambda_{\text {red }}$, respectively.

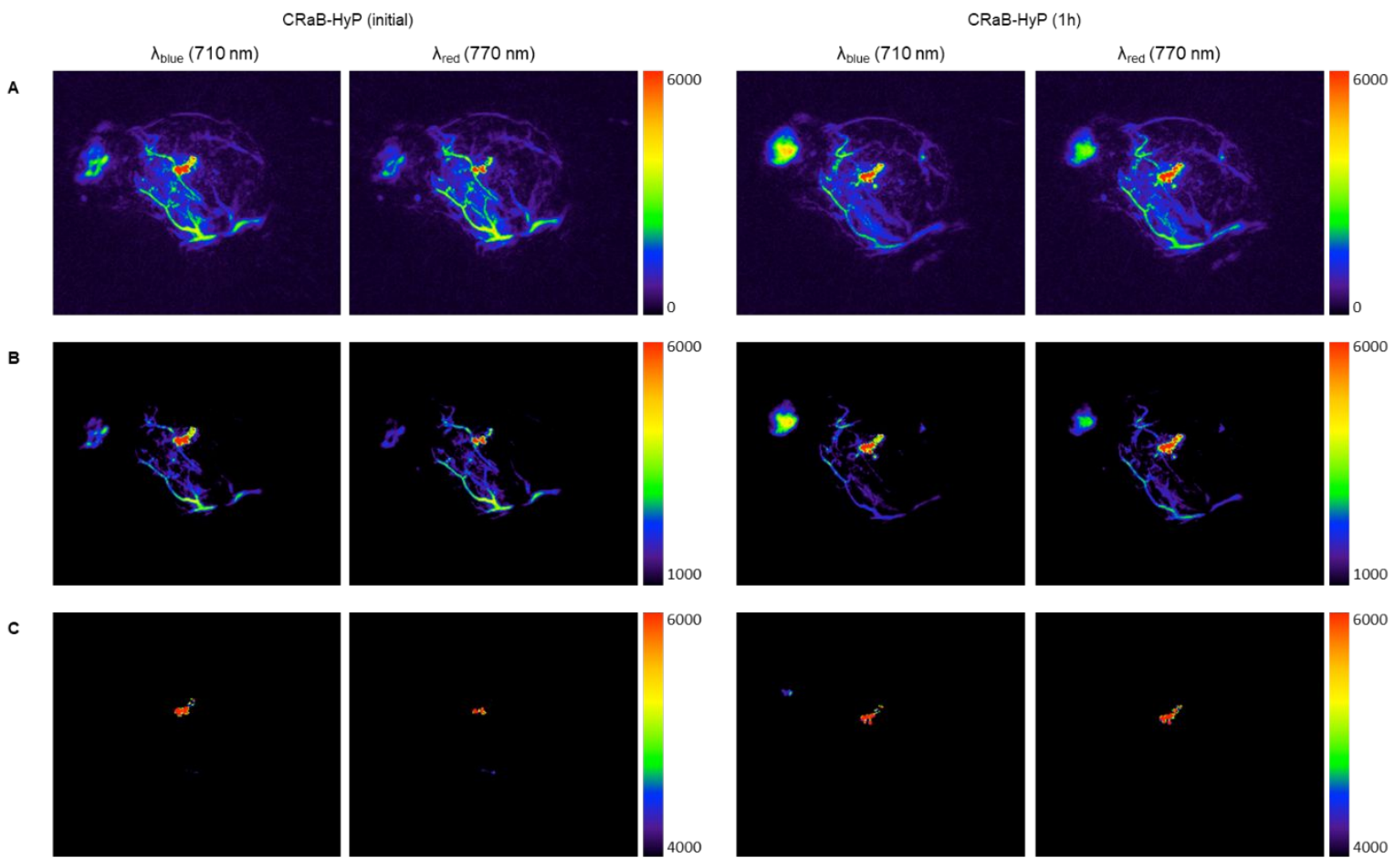

Figure S7. Representative PA images of tumors after injection of CRaB-HyP. Regions of interest containing pooled dye can be identified by visualization of only high intensity PA signals. 


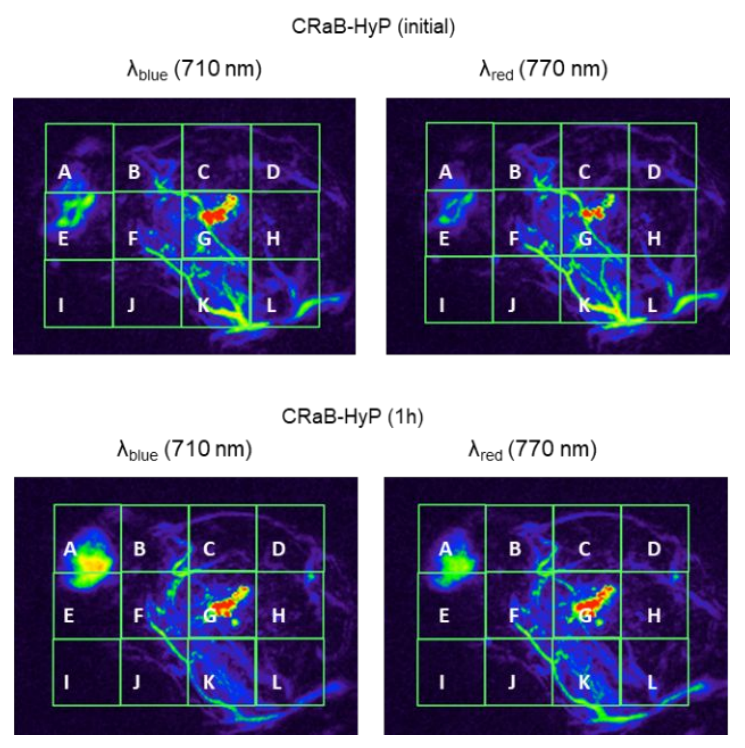

Figure S8. Sample grid analysis of PA images shown in Figure S7 validates that ratiometric fold turn-on is probe dependent. PA intensities are quantified below in Table S5.

Table S5. Sample quantitative analysis of PA intensities (as shown in Figure S2) showing selective ratiometric turn-on in the region of interest.

\begin{tabular}{|c|c|c|c|c|c|c|c|}
\hline & \multicolumn{3}{|c|}{ Initial } & \multicolumn{3}{c|}{$1 \mathrm{~h}$} & $\begin{array}{c}\text { Ratiometric } \\
\text { turn-on }\end{array}$ \\
\hline & $710 \mathrm{~nm}$ & $770 \mathrm{~nm}$ & Ratio & $710 \mathrm{~nm}$ & $770 \mathrm{~nm}$ & Ratio & \\
\hline A & 456.96 & 352.51 & 0.77 & 1083.71 & 773.99 & 0.71 & 0.93 \\
\hline B & 496.09 & 526.28 & 1.06 & 497.74 & 502.88 & 1.01 & 0.95 \\
\hline C & 409.49 & 388.84 & 0.95 & 423.21 & 453.31 & 1.07 & 1.13 \\
\hline D & 375.84 & 378.02 & 1.01 & 340.14 & 370.99 & 1.09 & 1.08 \\
\hline E & 777.74 & 624.13 & 0.80 & 477.45 & 405.11 & 0.85 & 1.06 \\
\hline F & 719.88 & 782.76 & 1.09 & 773.71 & 754.84 & 0.98 & 0.90 \\
\hline G & 1756.87 & 1442.86 & 0.82 & 1470.17 & 1662.40 & 1.13 & 1.38 \\
\hline H & 393.23 & 399.63 & 1.02 & 418.50 & 439.94 & 1.05 & 1.03 \\
\hline I & 217.58 & 201.45 & 0.93 & 200.07 & 207.67 & 1.04 & 1.12 \\
\hline J & 305.12 & 309.81 & 1.02 & 347.60 & 358.53 & 1.03 & 1.02 \\
\hline K & 1343.21 & 1466.64 & 1.09 & 1001.67 & 1210.96 & 1.21 & 1.11 \\
\hline L & 738.61 & 800.74 & 1.08 & 495.74 & 621.75 & 1.25 & 1.16 \\
\hline
\end{tabular}



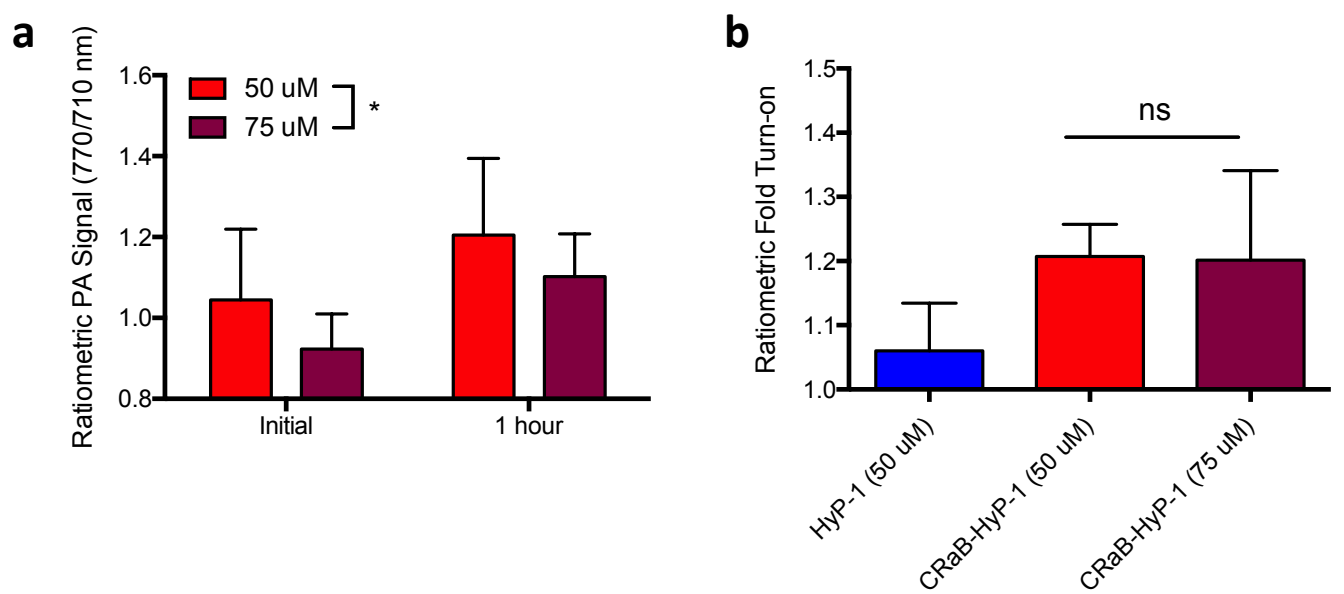

Figure S9. Dose dependence of ratiometric PA imaging with CRaB-HyP. a) Time and concentration dependence of ratiometric PA signal in hypoxic tumors. Signal ratio is consistently lower when higher dose is used, but still increases over time as expected. Data presented as mean \pm S.D. ( $\mathrm{n} \geq 6$ ). Statistical analysis performed using 2-way ANOVA. b) Ratiometric fold turn-on of HyP-1 and multiple concentrations of CRaB-HyP. Ratiometric fold turn-on of CRaB-HyP is consistent across multiple doses. Data presented as mean \pm S.D. $(n \geq 6)$. Statistical analysis performed using student's t-test. $* \mathrm{p}<0.05 ; \mathrm{ns}=$ not significant.
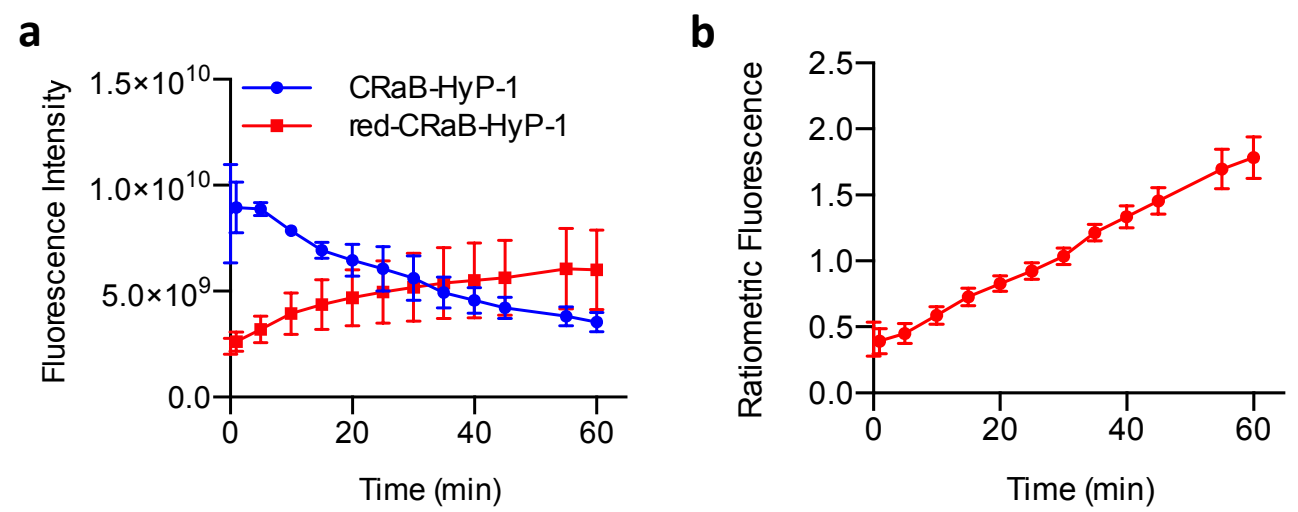

Figure S10. Fluorescence imaging of CRaB-HyP turnover in vivo following intratumoral injection $(50 \mu \mathrm{L}, 50 \mu \mathrm{M})$ of CRaB-HyP. Images were acquired at the indicated time points using excitation/emission filter sets of 675/720 nm (detection of CRaB-HyP) and 745/820 nm (detection of red-CRaB-HyP). a) Time-dependent change in tumor fluorescence intensity for individual filter sets. b) Time-dependent increase in fluorescence ratio (red-CRaB-HyP/CRaB-HyP). Data presented as mean \pm S.D. $(n=3)$. 
NMR Spectra of red-HyP analogues (Main Text, Compounds 1-6):

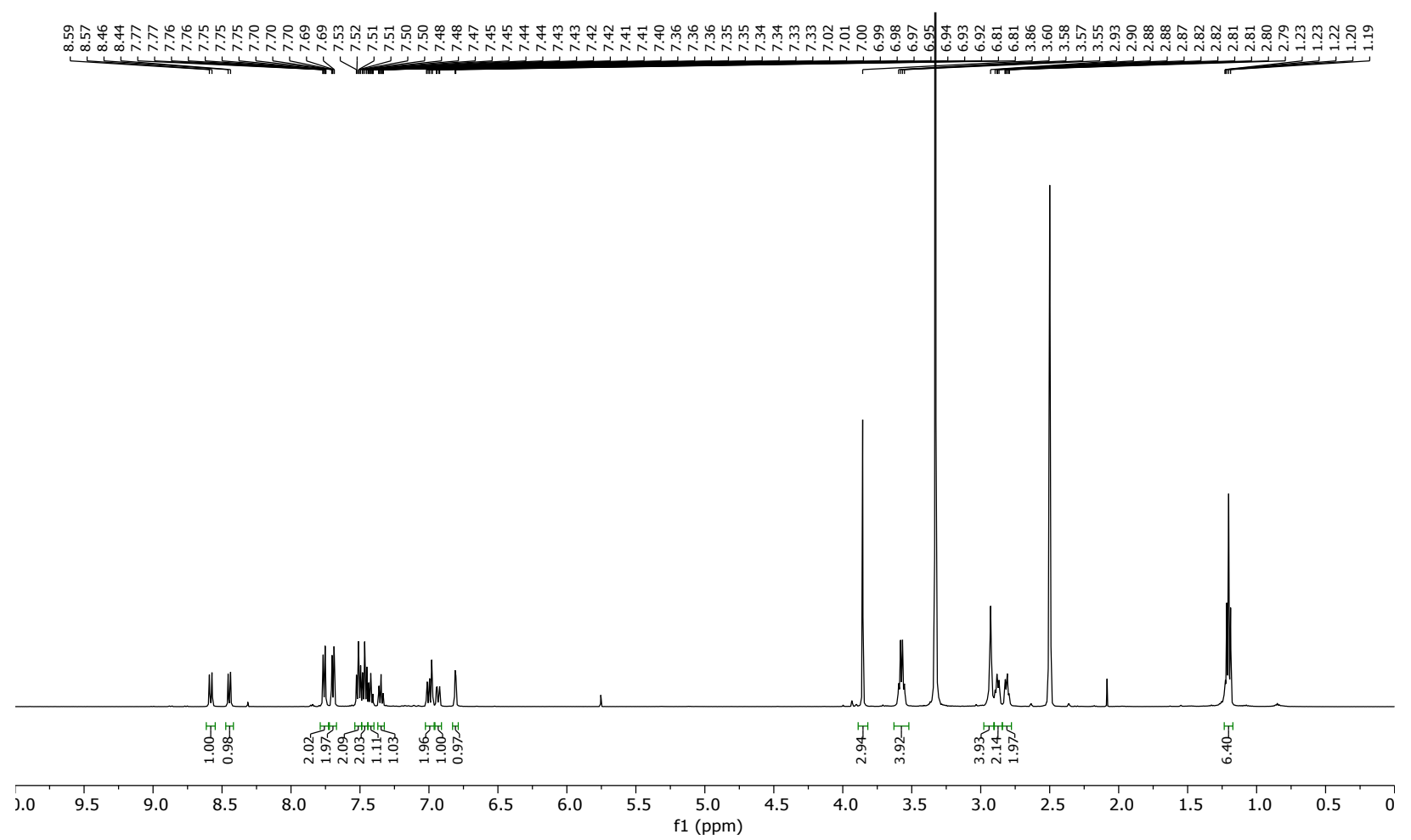

Figure S11. ${ }^{1} \mathrm{H}$ NMR of red-HyP analogue 1 (DMSO- $d_{6}$ ).

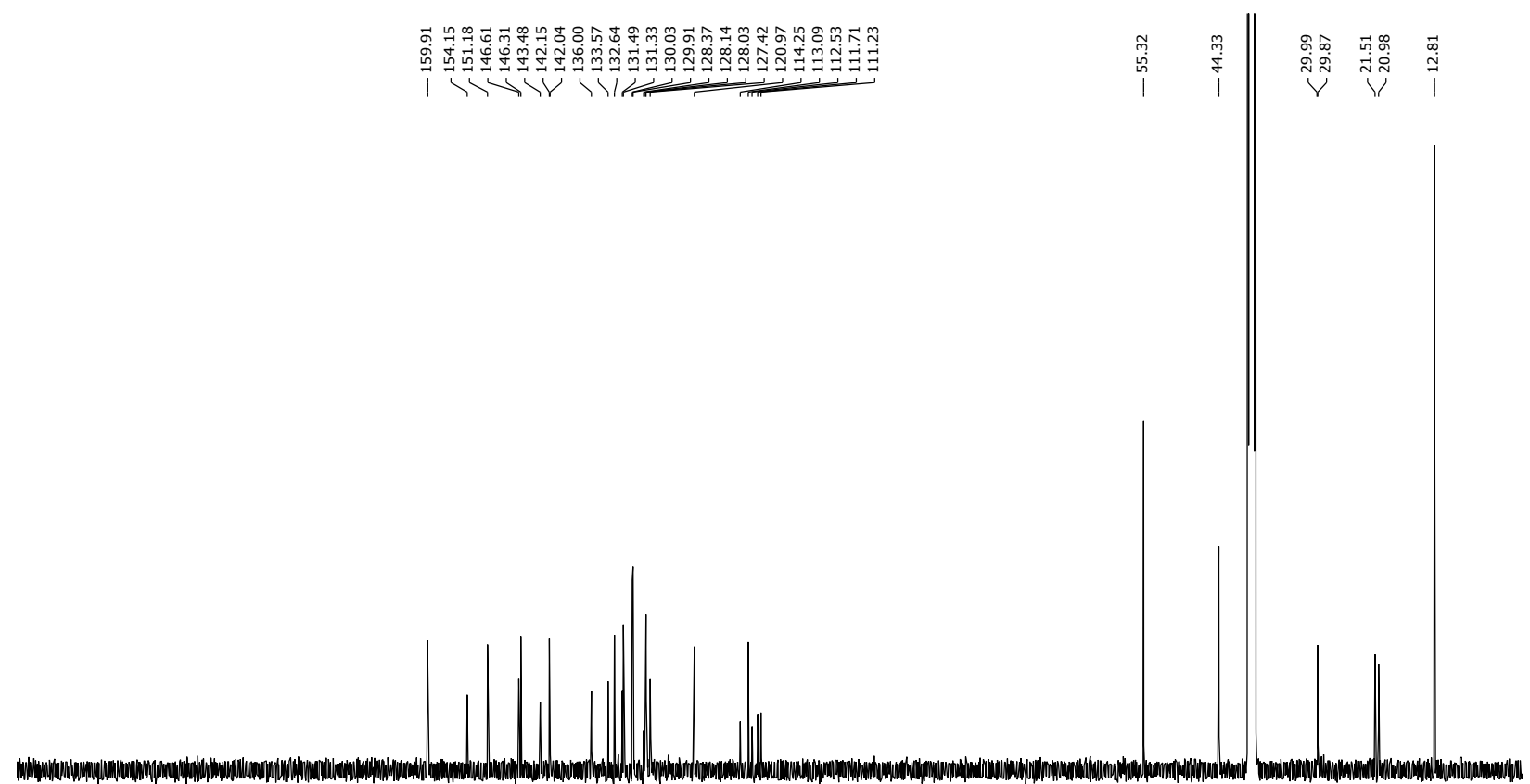

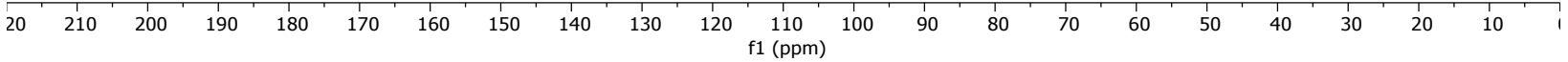

Figure S12. ${ }^{13} \mathrm{C}$ NMR of red-HyP analogue $1\left(\mathrm{DMSO}-d_{6}\right)$. 


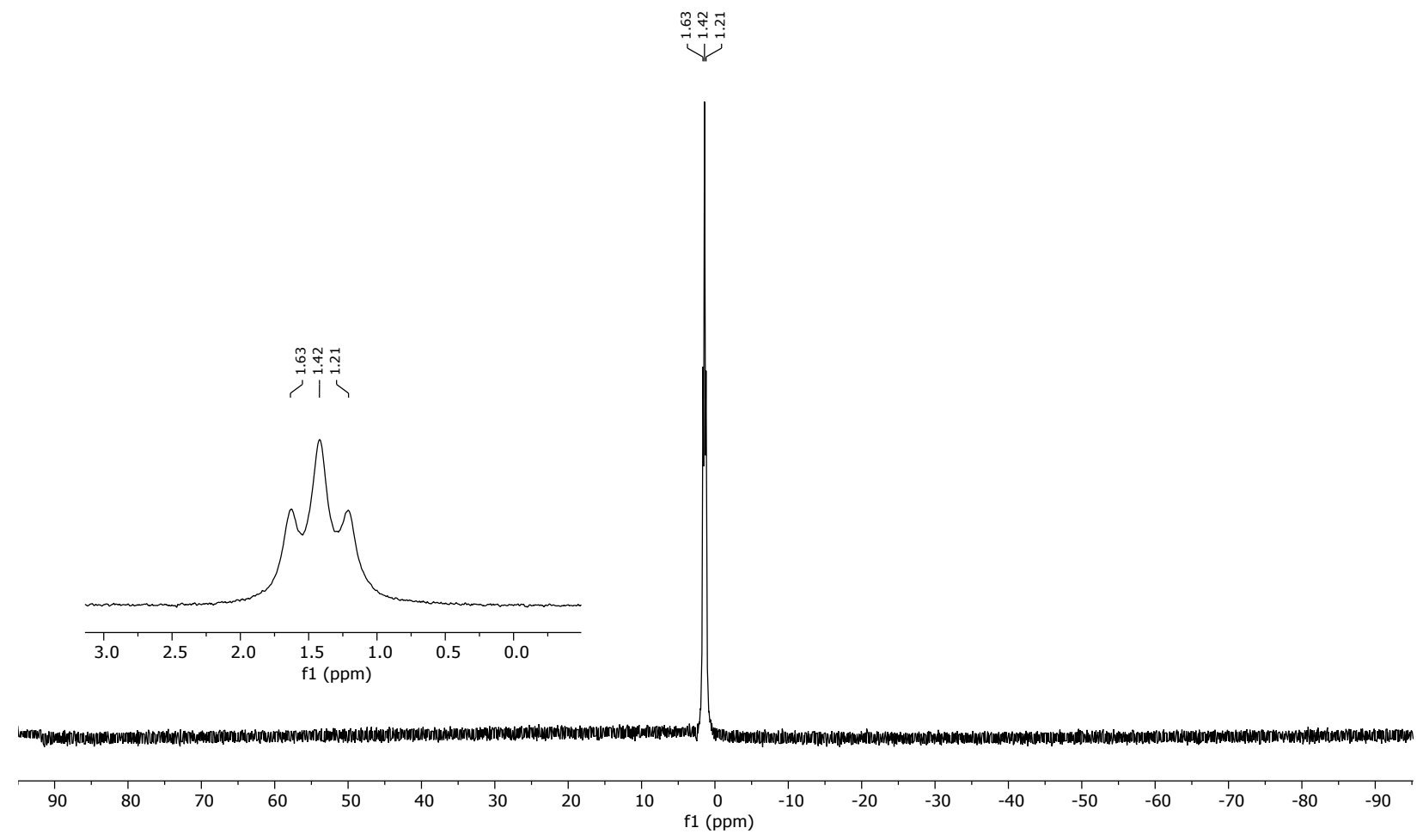

Figure S13. ${ }^{11} \mathrm{~B}$ NMR of red-HyP analogue 1 (DMSO- $d_{6}$ ).

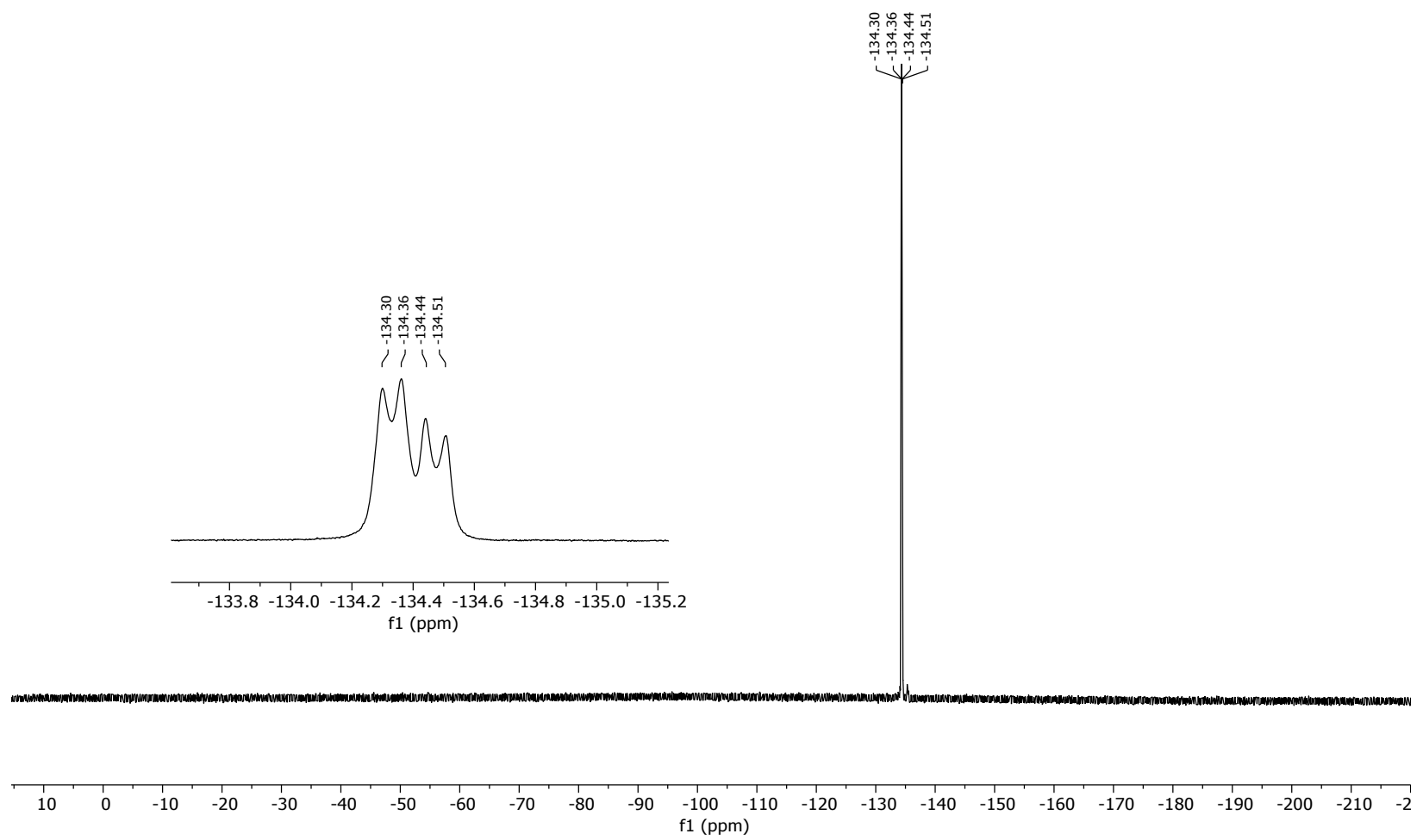

Figure S14. ${ }^{19} \mathrm{~F}$ NMR of red-HyP analogue $1\left(\mathrm{DMSO}-d_{6}\right)$. 


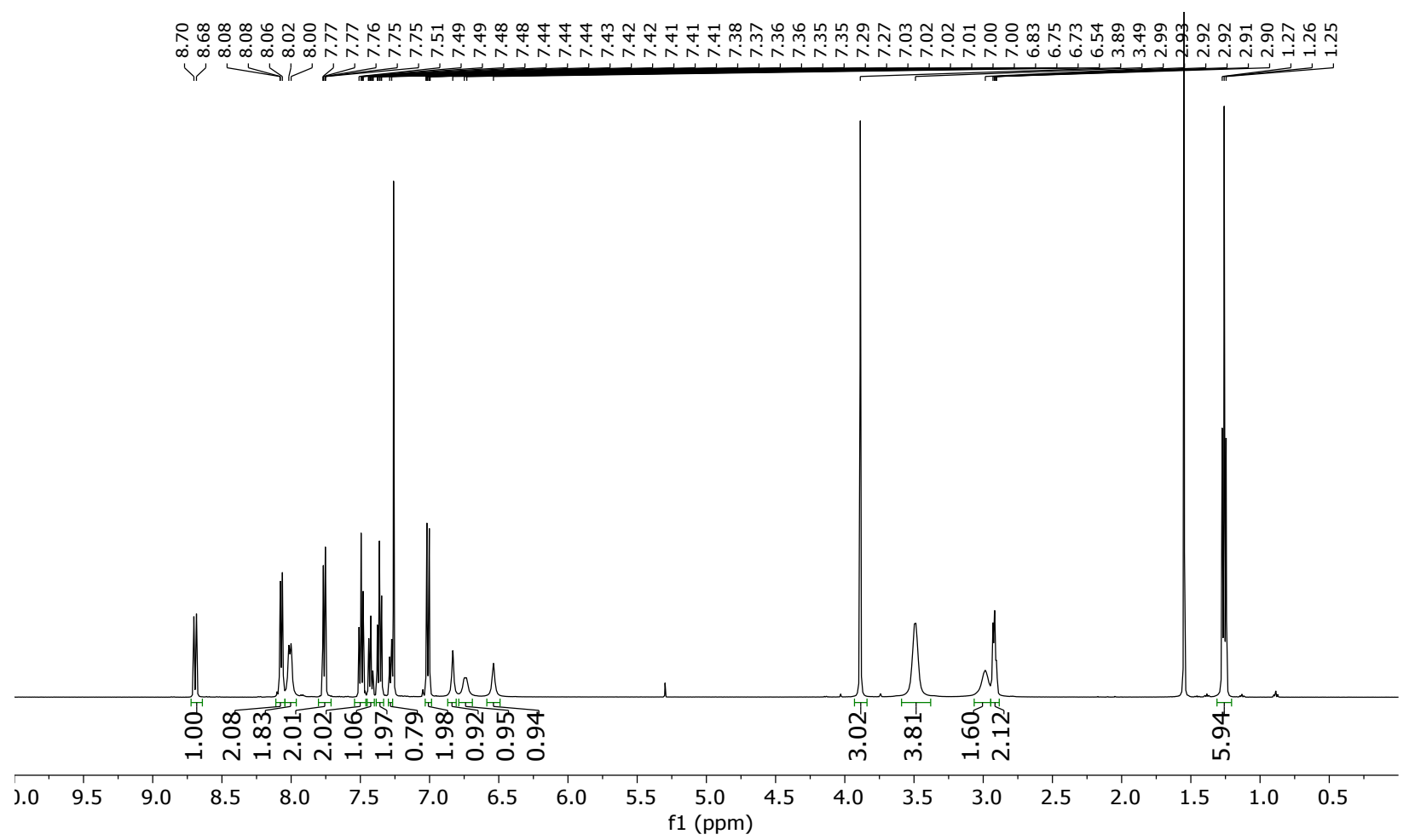

Figure S15. ${ }^{1} \mathrm{H}$ NMR of red-HyP analogue $2\left(\mathrm{CDCl}_{3}\right)$.

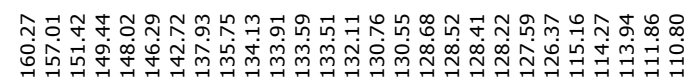

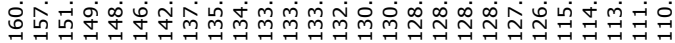

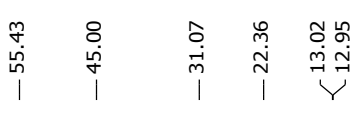

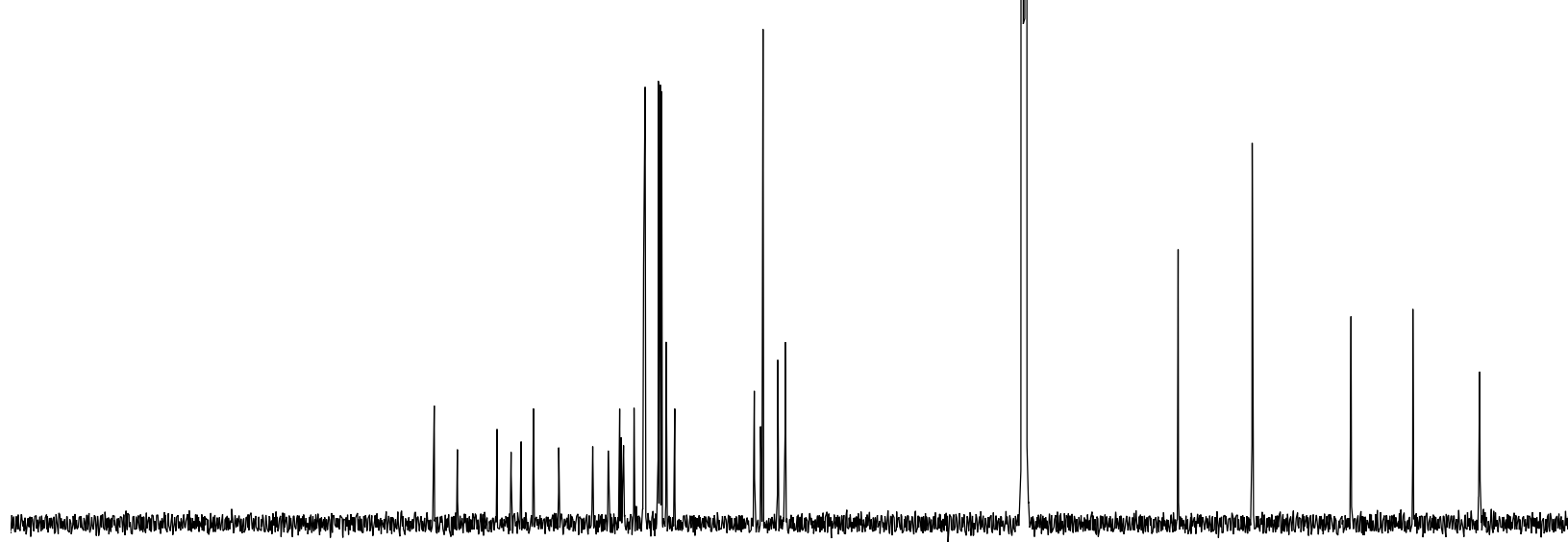

$\begin{array}{lllllllllllll}20 & 210 & 200 & 190 & 180 & 170 & 160 & 150 & 140 & 130 & 120 & 110 & 100\end{array}$

Figure S16. ${ }^{13} \mathrm{C}$ NMR of red-HyP analogue $2\left(\mathrm{CDCl}_{3}\right)$. 


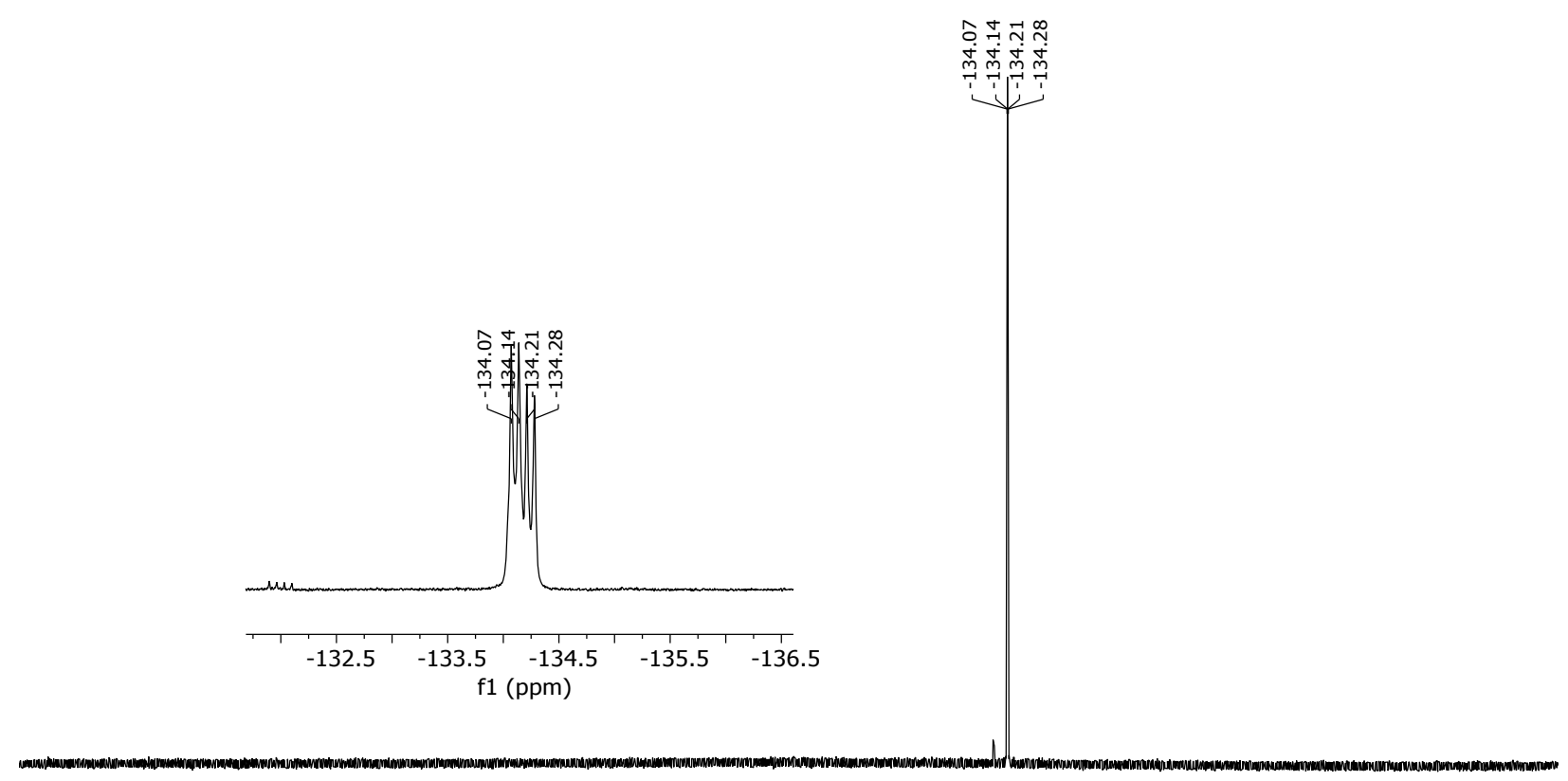

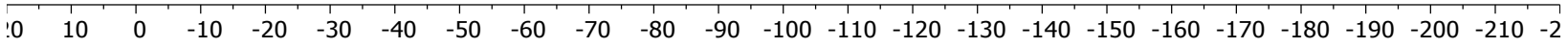
f1 (ppm)

Figure S17. ${ }^{19} \mathrm{~F}$ NMR of red-HyP analogue $2\left(\mathrm{CDCl}_{3}\right)$.

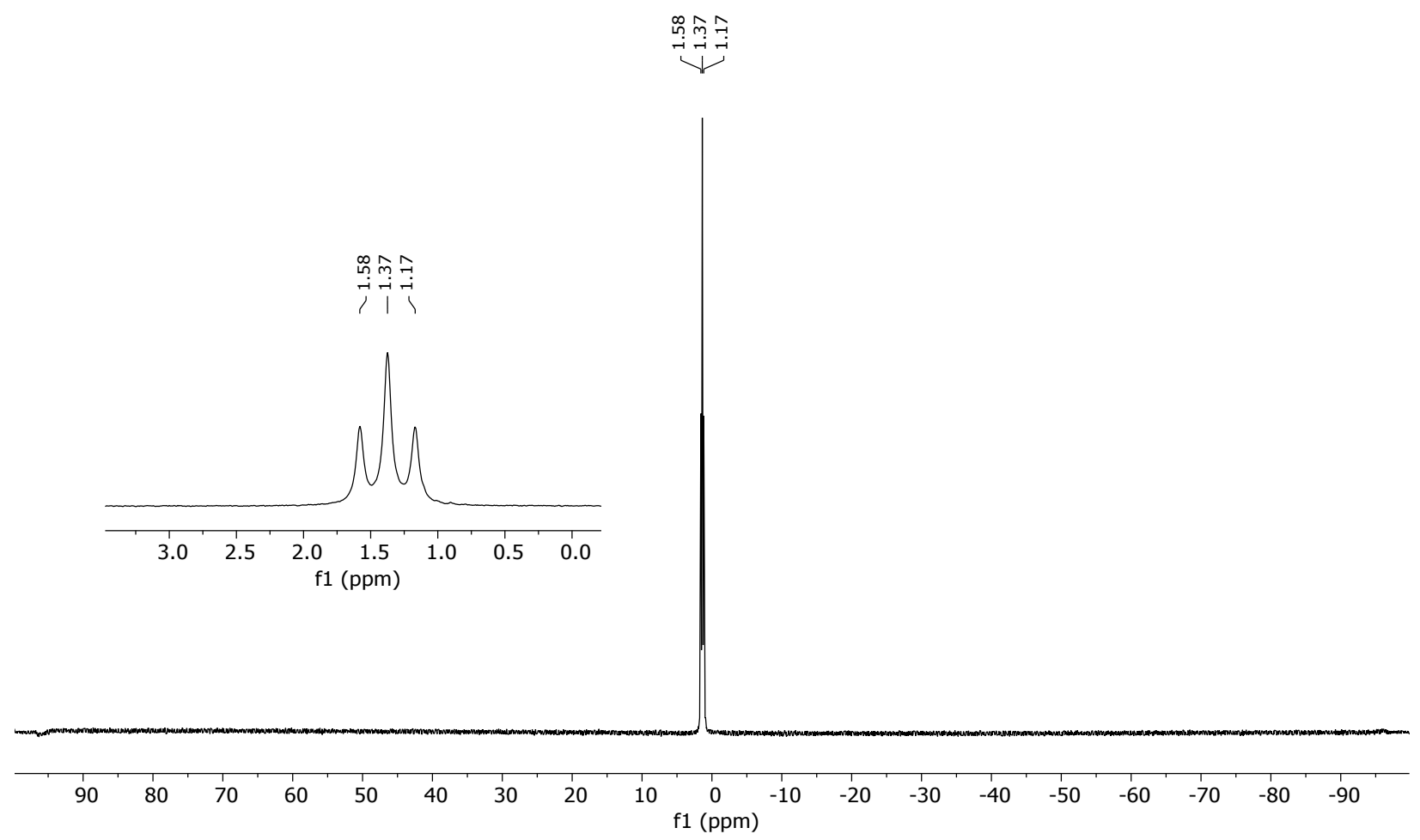

Figure S18. ${ }^{11} \mathrm{~B}$ NMR of red-HyP analogue $2\left(\mathrm{CDCl}_{3}\right)$. 


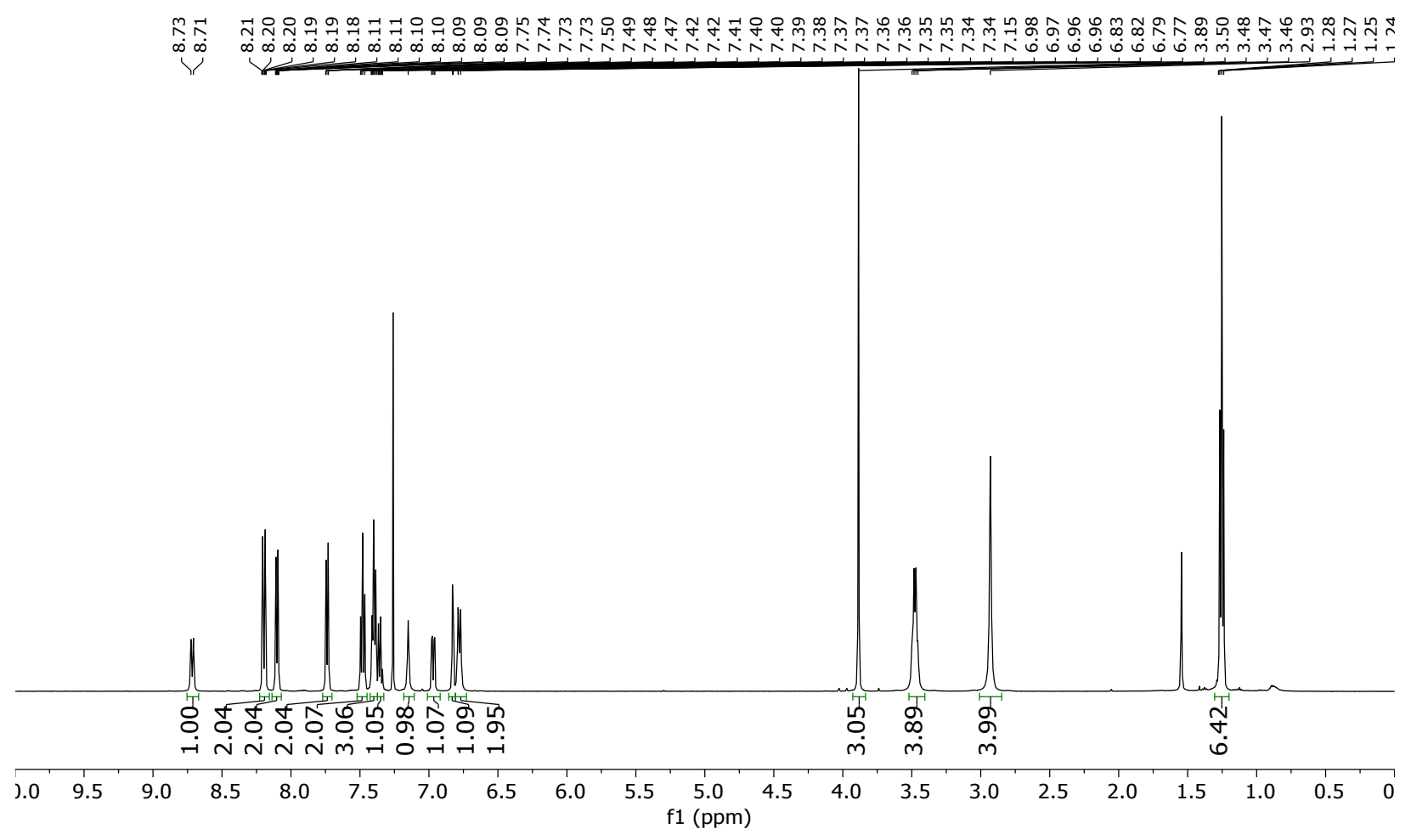

Figure S19. ${ }^{1} \mathrm{H}$ NMR of red-HyP analogue $3\left(\mathrm{CDCl}_{3}\right)$.

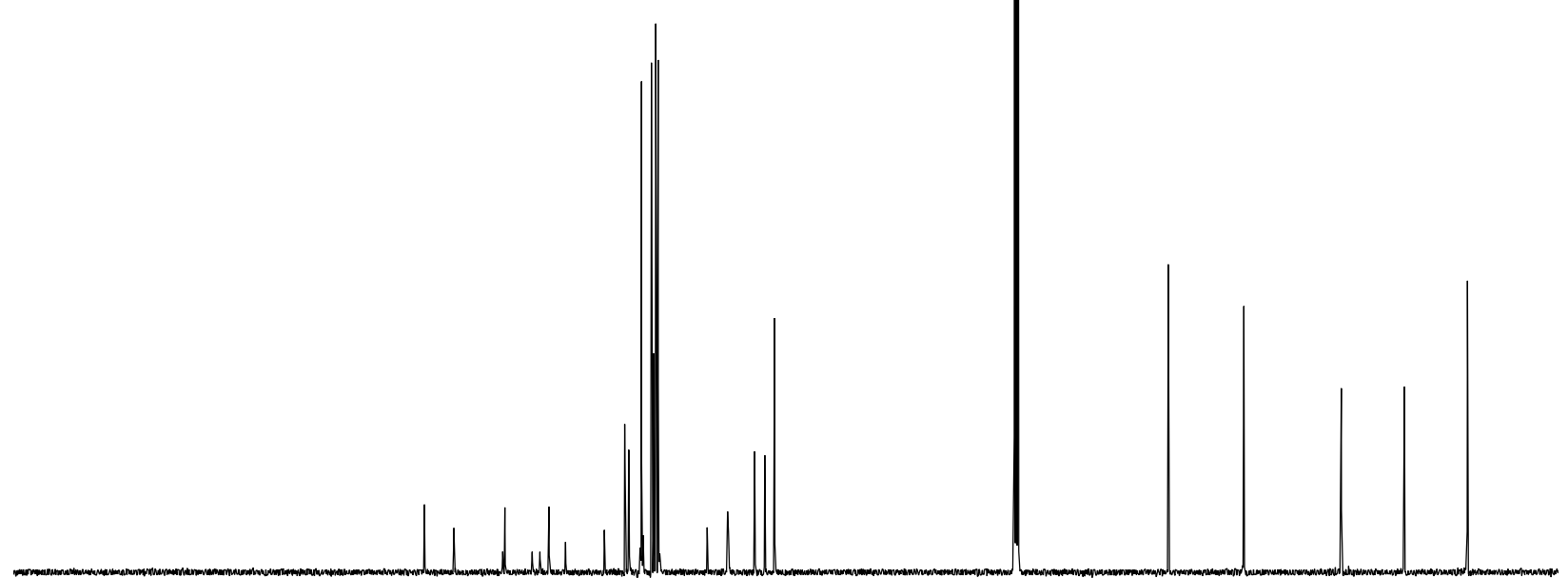

\begin{tabular}{lllllllllllllllllllllllllll}
\hline 20 & 210 & 200 & 190 & 180 & 170 & 160 & 150 & 140 & 130 & 120 & $\begin{array}{l}110 \\
\mathrm{f} 1\end{array}(\mathrm{ppm})$ & 100 & 90 & 80 & 70 & 60 & 50 & 40 & 30 & 20 & 10 & 1
\end{tabular}

Figure S20. ${ }^{13} \mathrm{C}$ NMR of red-HyP analogue $3\left(\mathrm{CDCl}_{3}\right)$. 


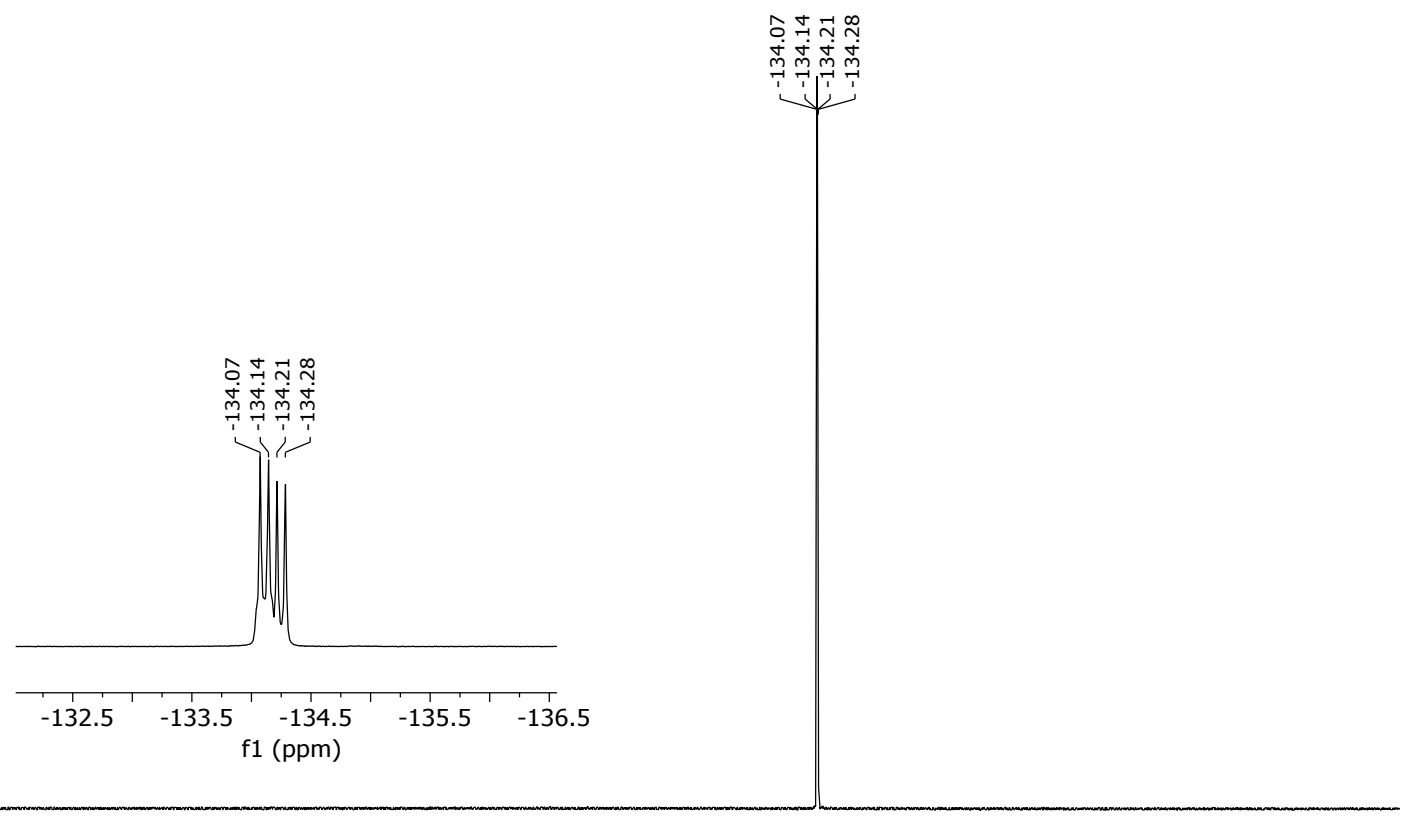

\begin{tabular}{rlllllllllllllllllllllllll}
\hline 20 & 10 & 0 & -10 & -20 & -30 & -40 & -50 & -60 & -70 & -80 & -90 & -100 & -110 & -120 & -130 & -140 & -150 & -160 & -170 & -180 & -190 & -200 & -210 & -2
\end{tabular}

Figure S21. ${ }^{19} \mathrm{~F}$ NMR of red-HyP analogue $3\left(\mathrm{CDCl}_{3}\right)$.

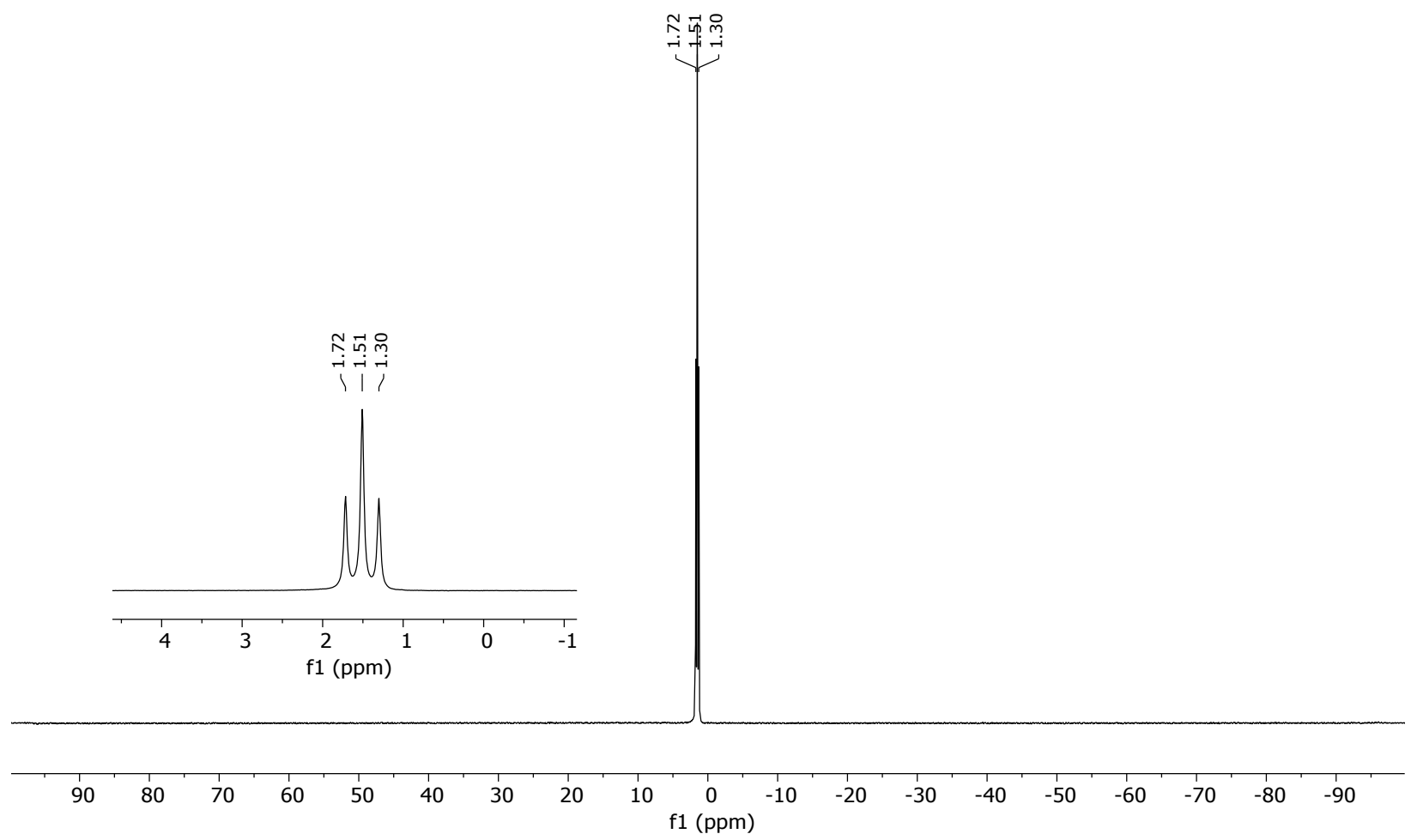

Figure S22. ${ }^{11} \mathrm{~B}$ NMR of red-HyP analogue $3\left(\mathrm{CDCl}_{3}\right)$. 


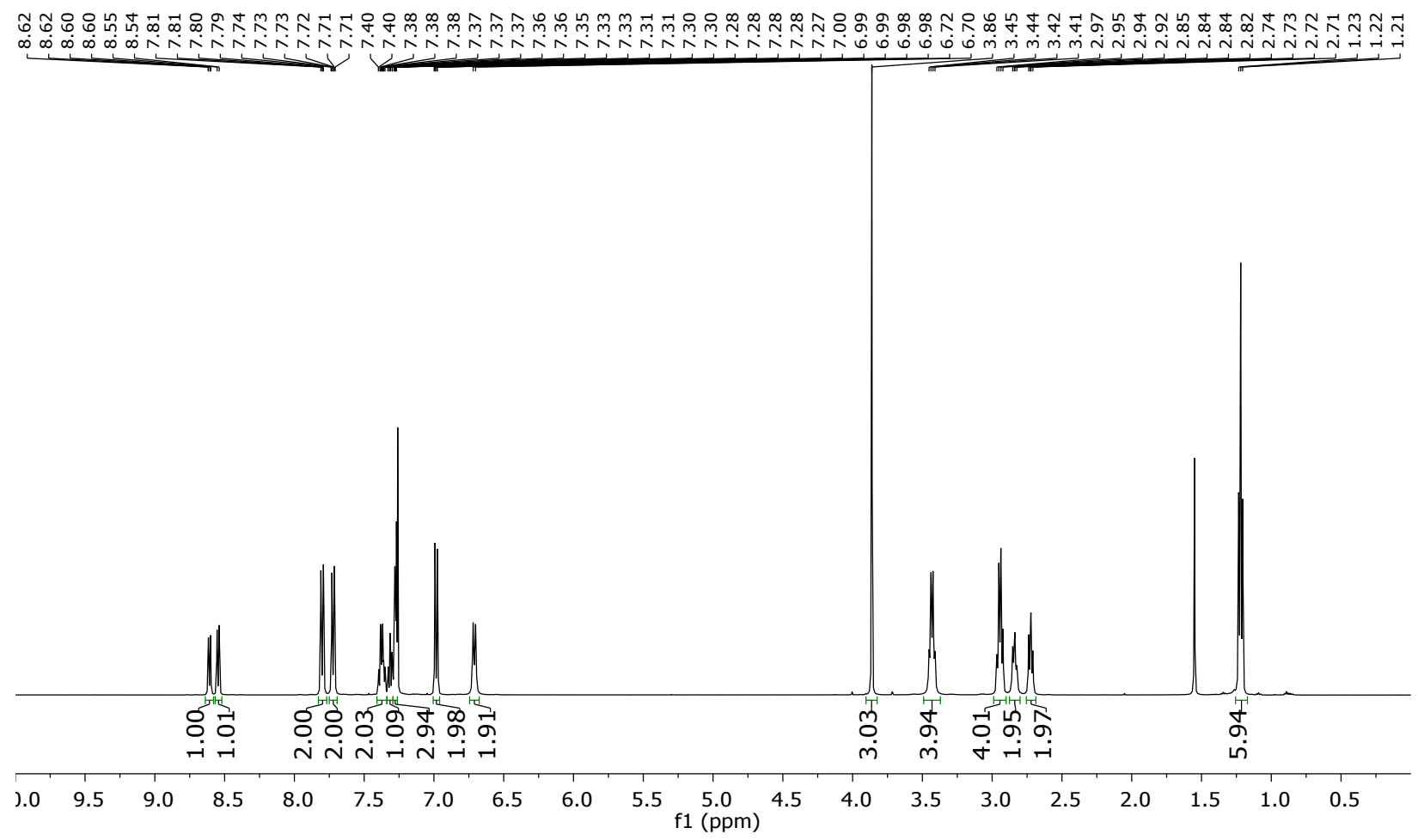

Figure S23. ${ }^{1} \mathrm{H}$ NMR of red-HyP analogue $4\left(\mathrm{CDCl}_{3}\right)$.
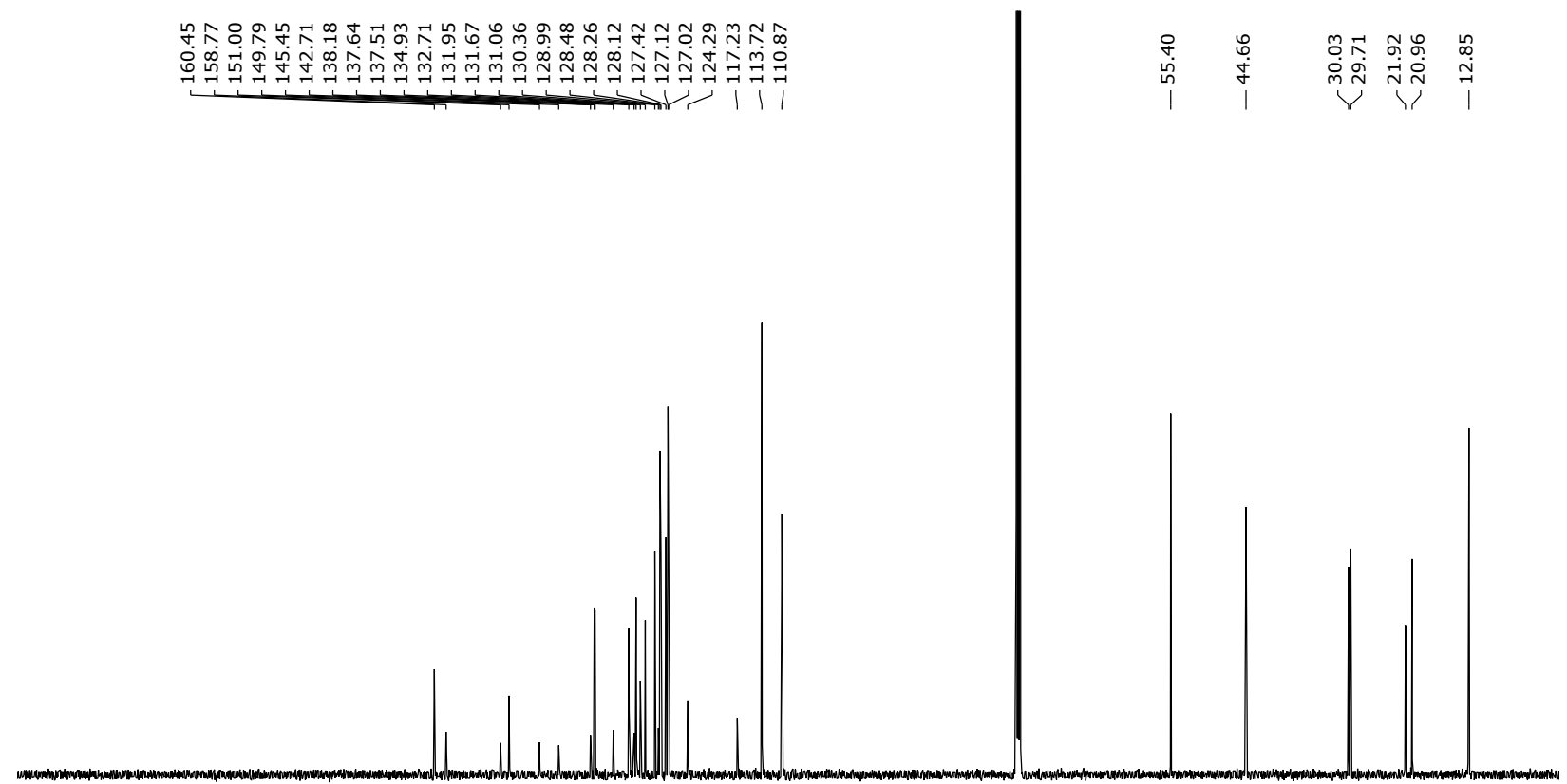

${ }^{13} \mathrm{C} 1(\mathrm{ppm}){ }^{100}$

Figure S24. ${ }^{13} \mathrm{C}$ NMR of red-HyP analogue $4\left(\mathrm{CDCl}_{3}\right)$. 


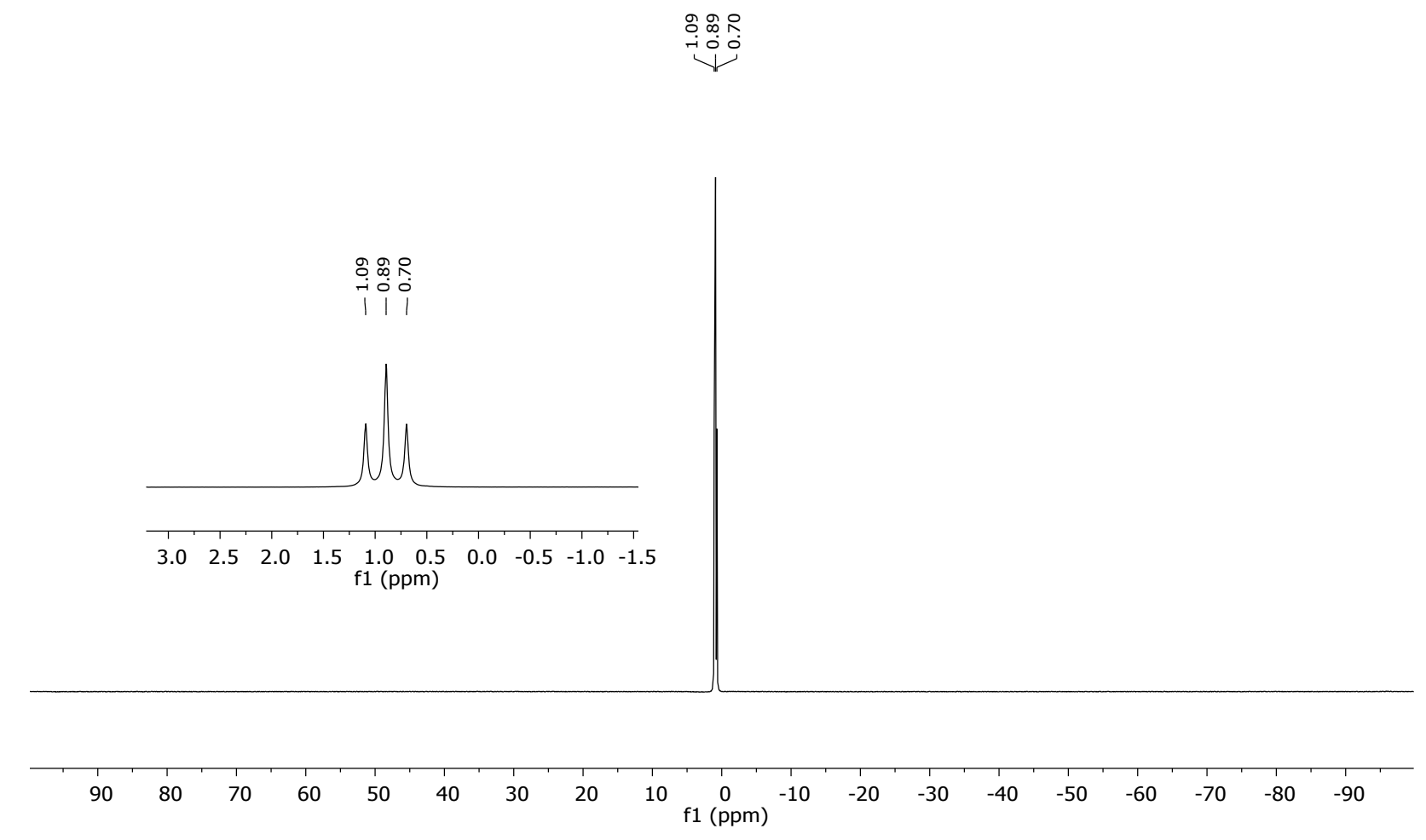

Figure S25. ${ }^{11} \mathrm{~B}$ NMR of red-HyP analogue $4\left(\mathrm{CDCl}_{3}\right)$.
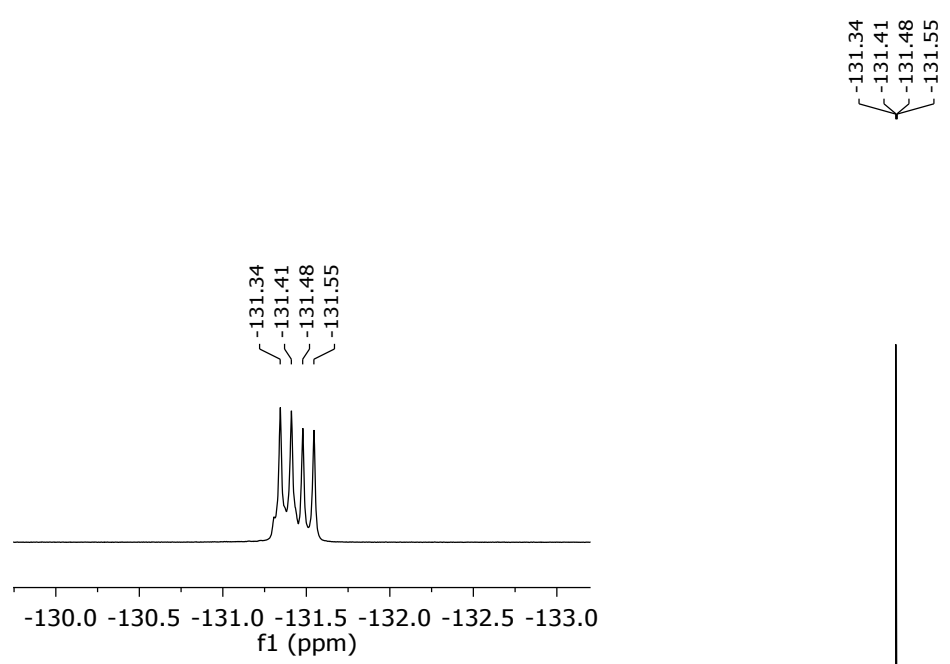

\begin{tabular}{|c|c|c|c|c|c|c|c|c|c|c|c|c|c|c|c|c|c|c|c|c|}
\hline & 1 & 1 & $T$ & 1 & $T$ & 1 & $T$ & $T$ & $T$ & $T$ & $1,1 \quad 1$ & 1 & 1 & 1 & 1 & 1 & 1 & 1 & 1 & 1 \\
\hline$! 0$ & 10 & 0 & -10 & -20 & -30 & -40 & -50 & -60 & -70 & -80 & $\begin{array}{c}-90 \begin{array}{c}-100-110 \\
\mathrm{f} 1(\mathrm{ppm})\end{array}\end{array}$ & -120 & -130 & -140 & -150 & -160 & -170 & -180 & -190 & $-200-210$ \\
\hline
\end{tabular}

Figure S26. ${ }^{19} \mathrm{~F}$ NMR of red-HyP analogue $4\left(\mathrm{CDCl}_{3}\right)$. 

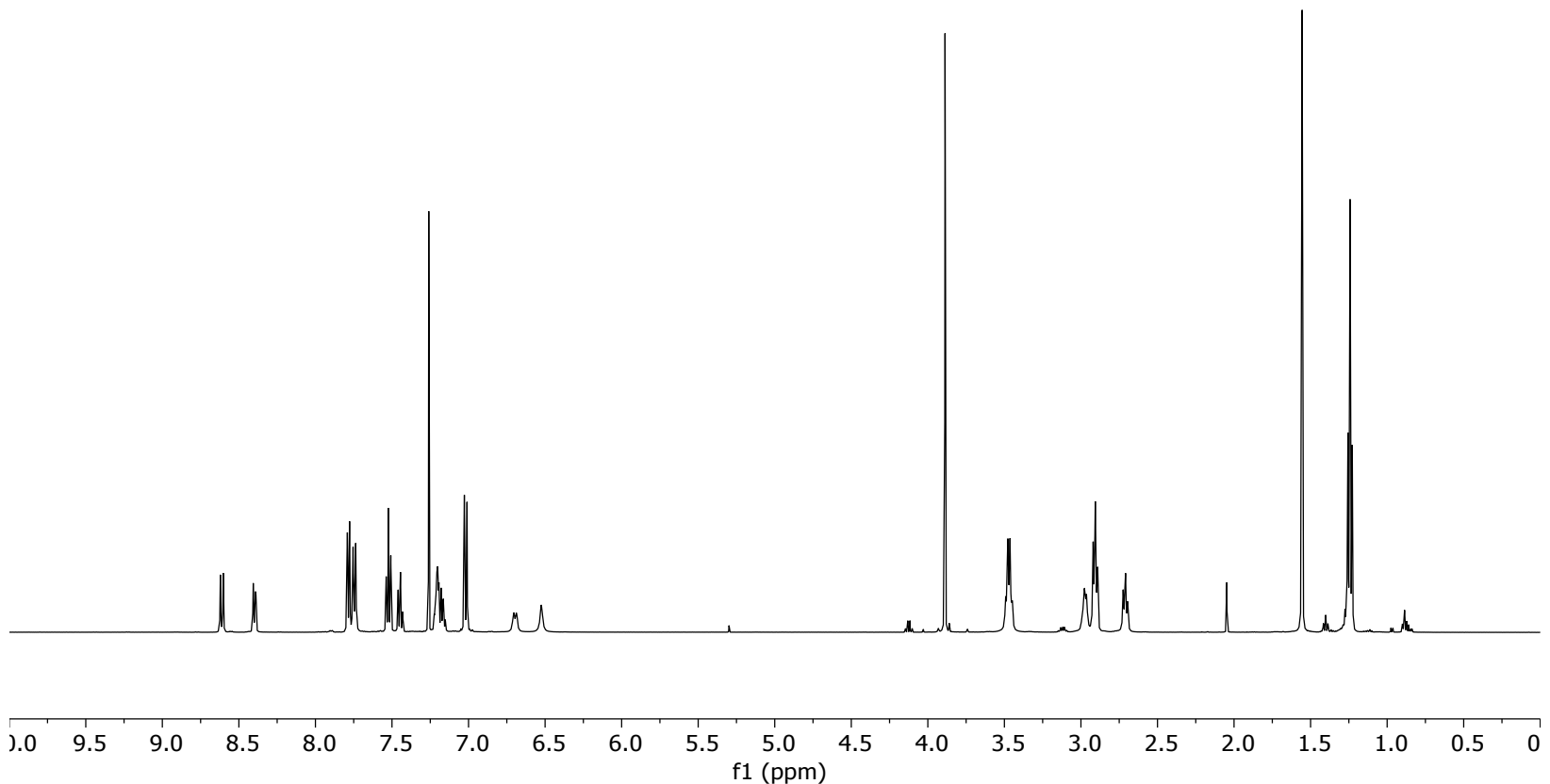

Figure S27. ${ }^{1} \mathrm{H}$ NMR of red-HyP analogue $5\left(\mathrm{CDCl}_{3}\right)$.

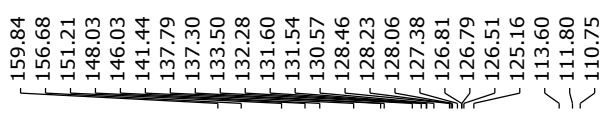

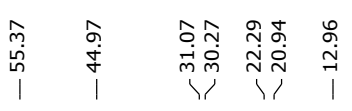

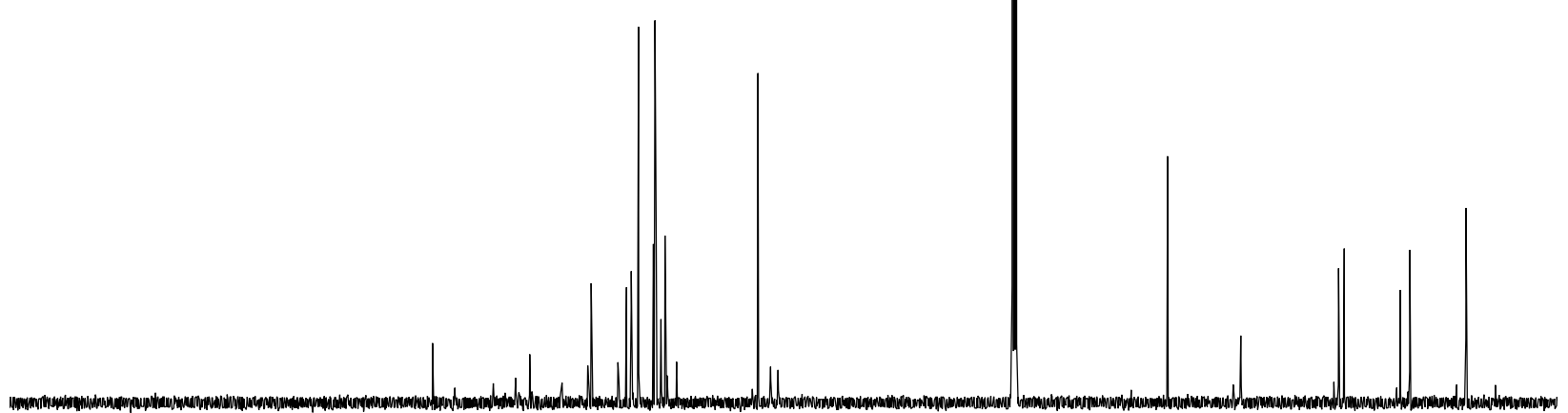

$\begin{array}{llllllllllllllllllllllllll}20 & 210 & 200 & 190 & 180 & 170 & 160 & 150 & 140 & 130 & 120 & \begin{array}{c}110 \\ \mathrm{fpm})\end{array} & 100 & 90 & 80 & 70 & 60 & 50 & 40 & 30 & 20 & 10 & 1\end{array}$

Figure S28. ${ }^{13} \mathrm{C}$ NMR of red-HyP analogue $5\left(\mathrm{CDCl}_{3}\right)$. 


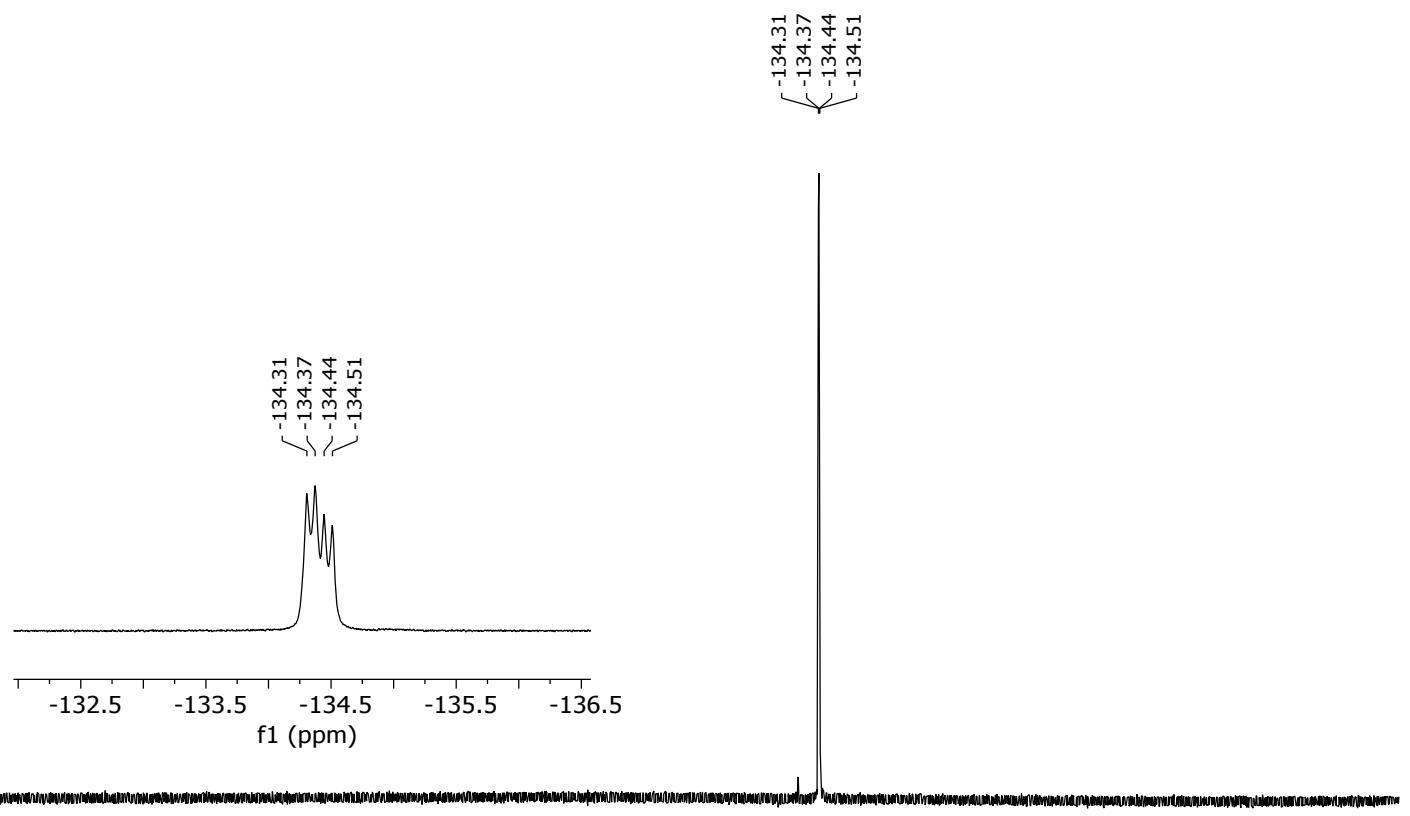

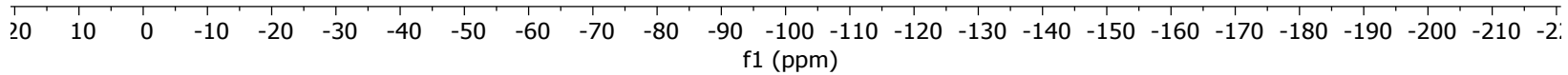

Figure S29. ${ }^{19} \mathrm{~F}$ NMR of red-HyP analogue $5\left(\mathrm{CDCl}_{3}\right)$.

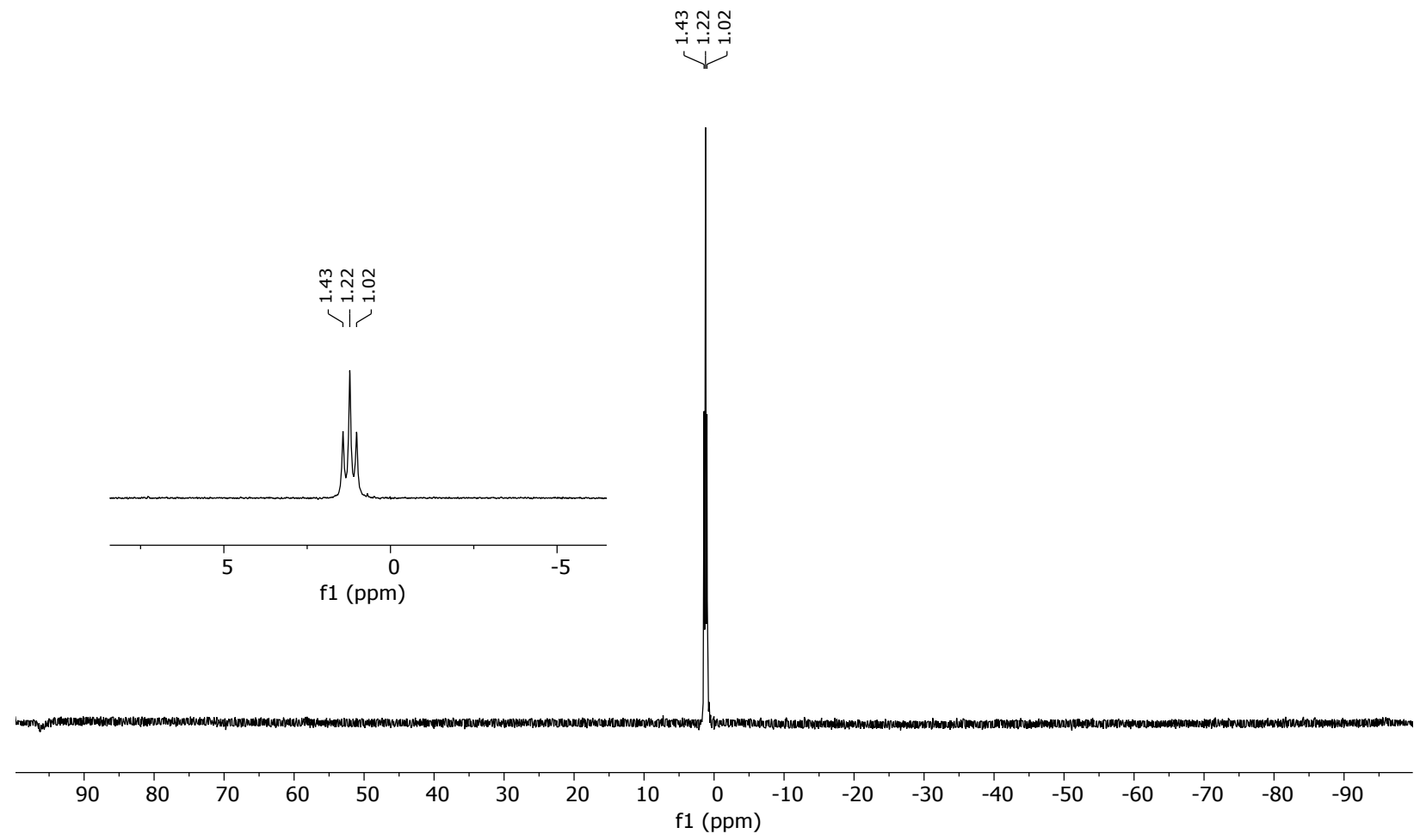

Figure S30. ${ }^{11} \mathrm{~B}$ NMR of red-HyP analogue $5\left(\mathrm{CDCl}_{3}\right)$. 


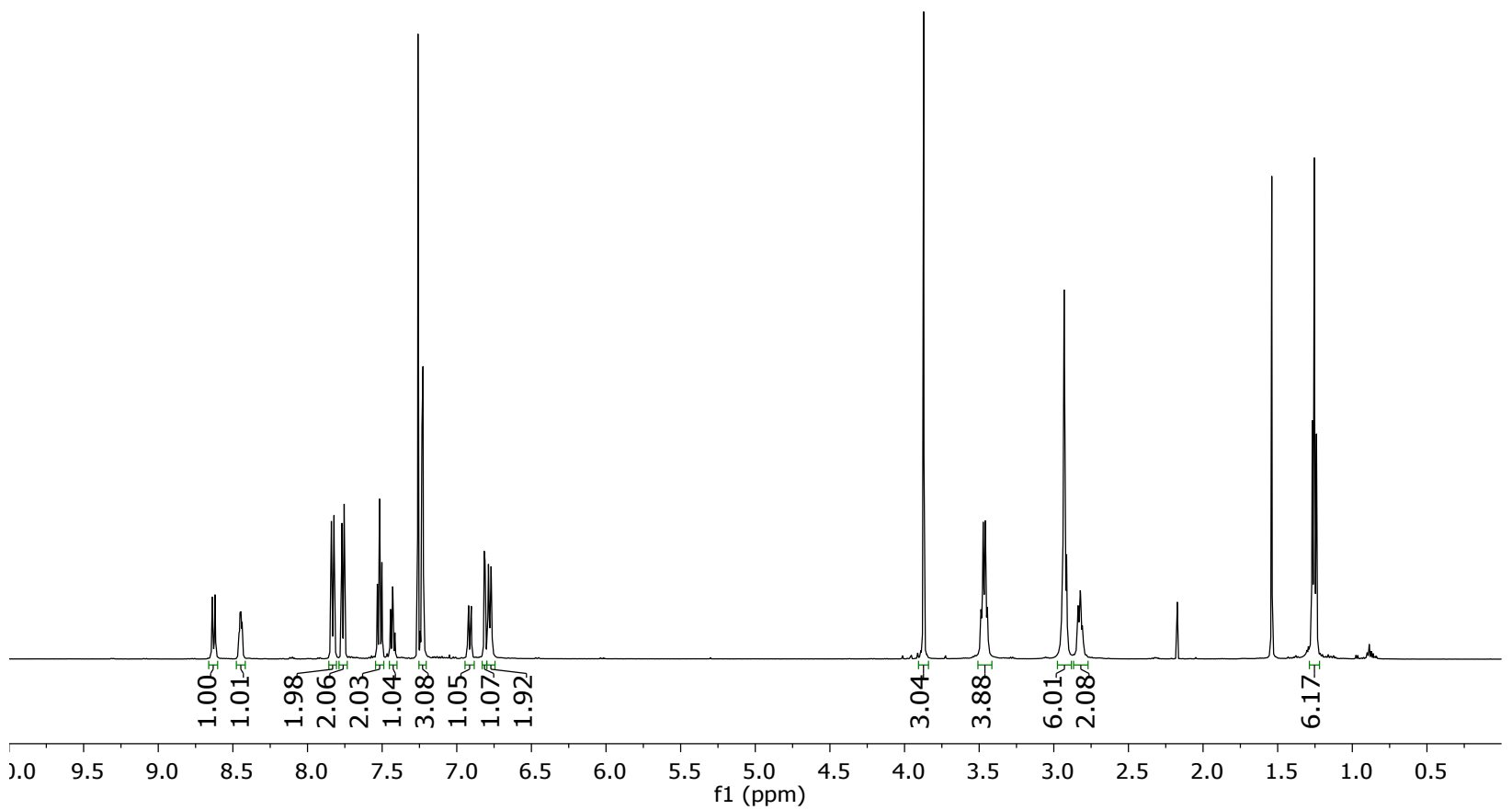

Figure S31. ${ }^{1} \mathrm{H}$ NMR of red-HyP analogue $6\left(\mathrm{CDCl}_{3}\right)$.
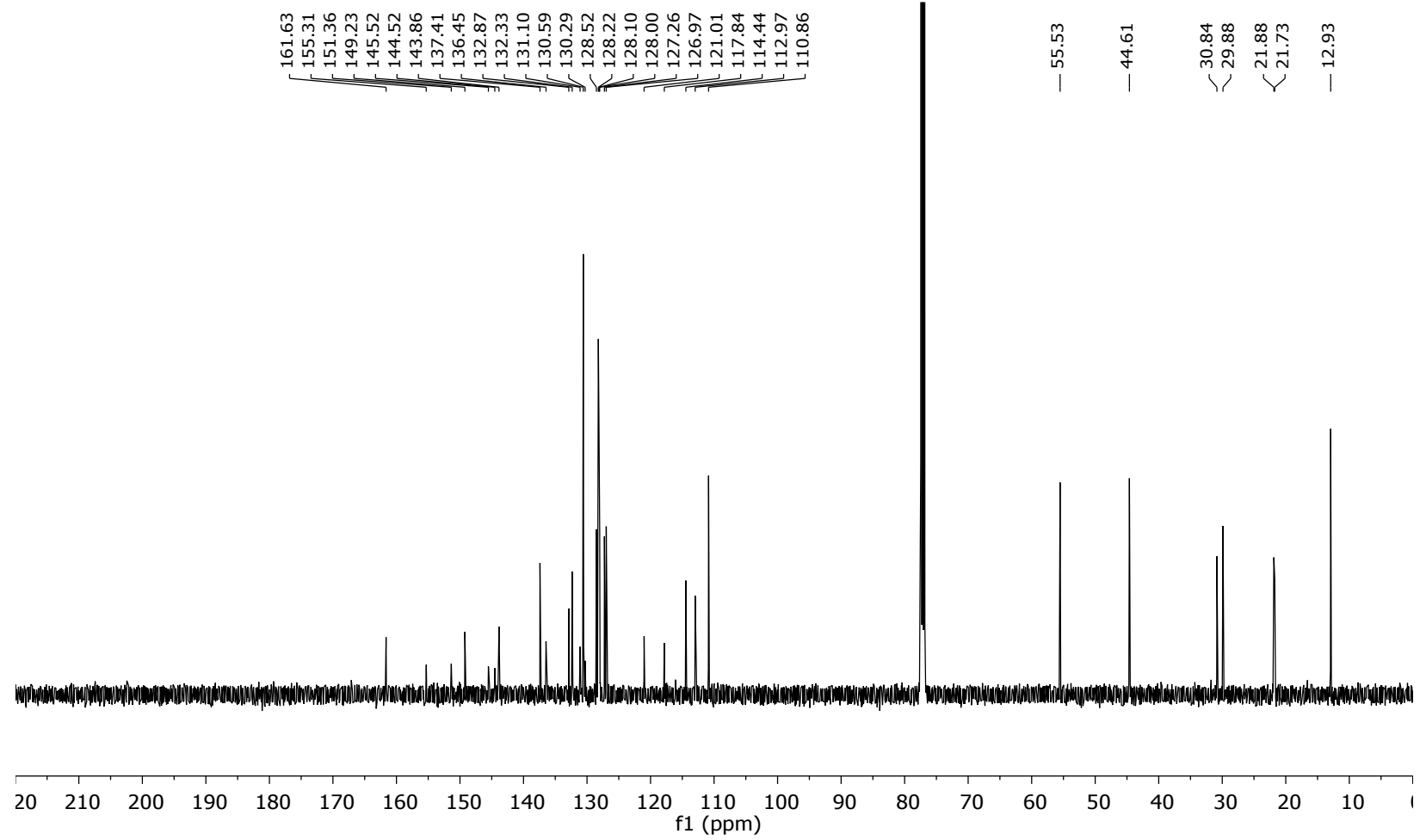

Figure S32. ${ }^{13} \mathrm{C}$ NMR of red-HyP analogue $6\left(\mathrm{CDCl}_{3}\right)$. 


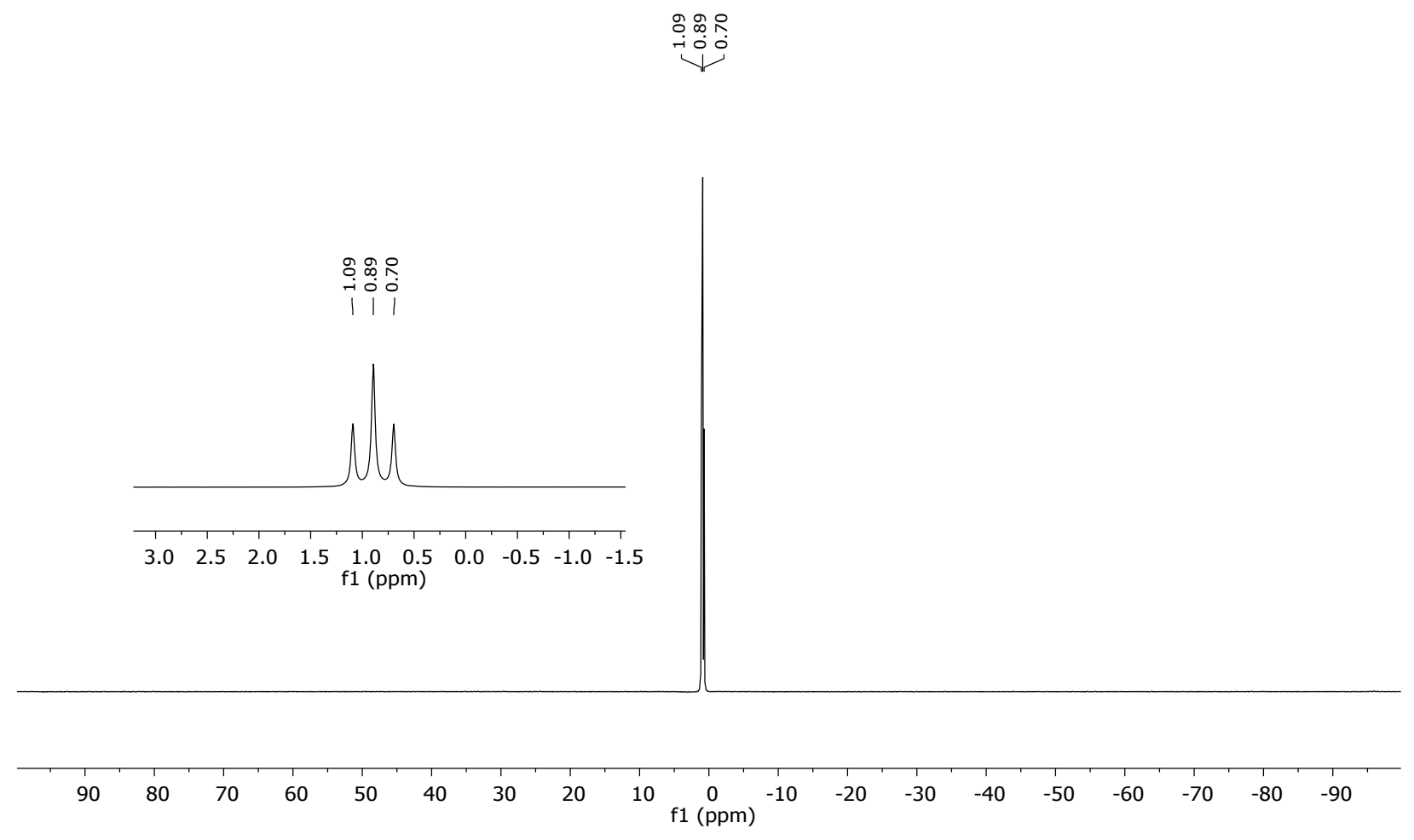

Figure S33. ${ }^{11} \mathrm{~B}$ NMR of red-HyP analogue $6\left(\mathrm{CDCl}_{3}\right)$.

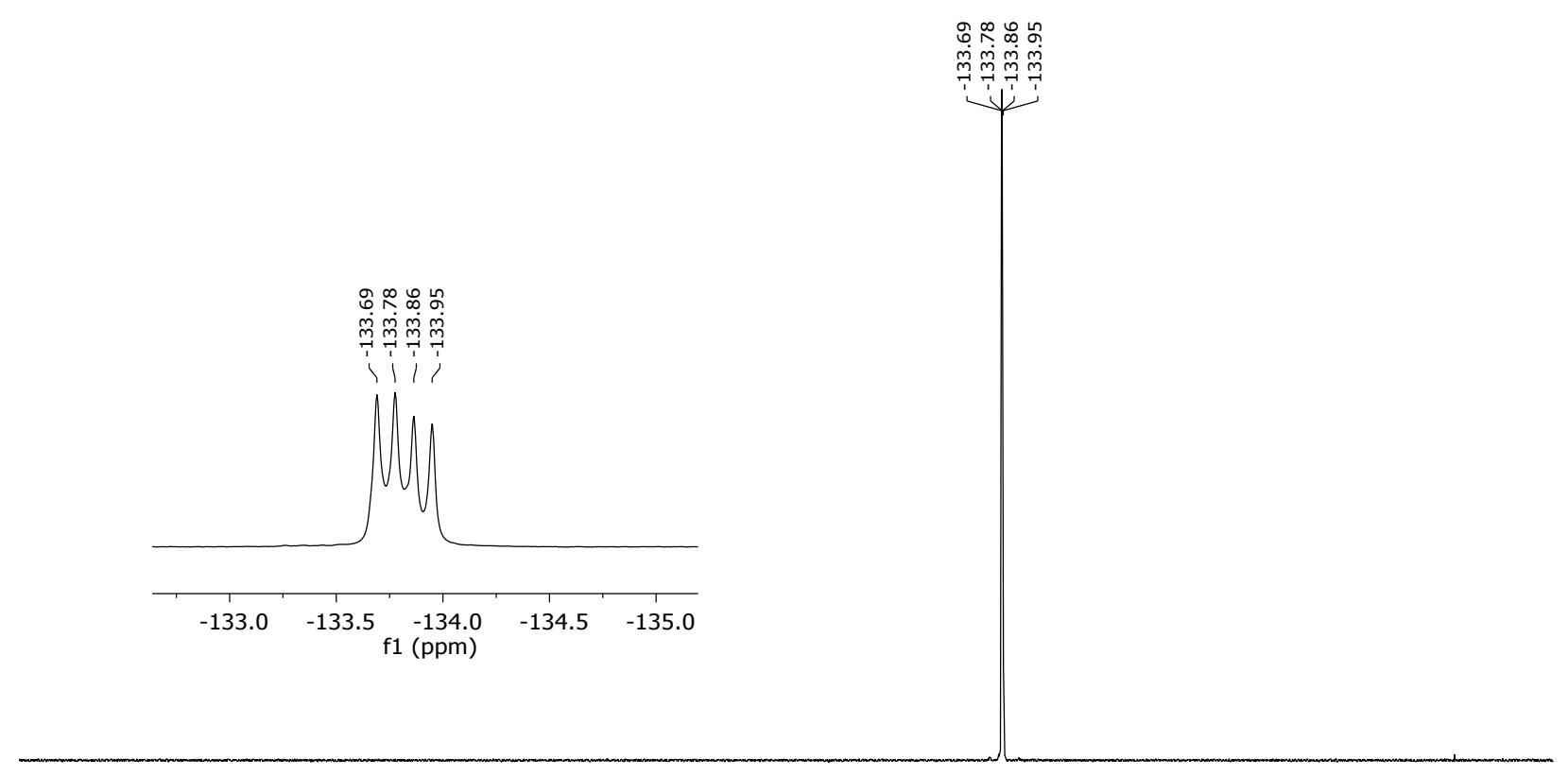

\begin{tabular}{lllllllllllllllllllllllll}
\hline 0 & 10 & 0 & -10 & -20 & -30 & -40 & -50 & -60 & -70 & -80 & -90 & -100 & -110 & -120 & -130 & -140 & -150 & -160 & -170 & -180 & -190 & -200 & -210 & -2
\end{tabular}

Figure S34. ${ }^{19} \mathrm{~F}$ NMR of red-HyP analogue $6\left(\mathrm{CDCl}_{3}\right)$. 
NMR Spectra of Probes and Products:

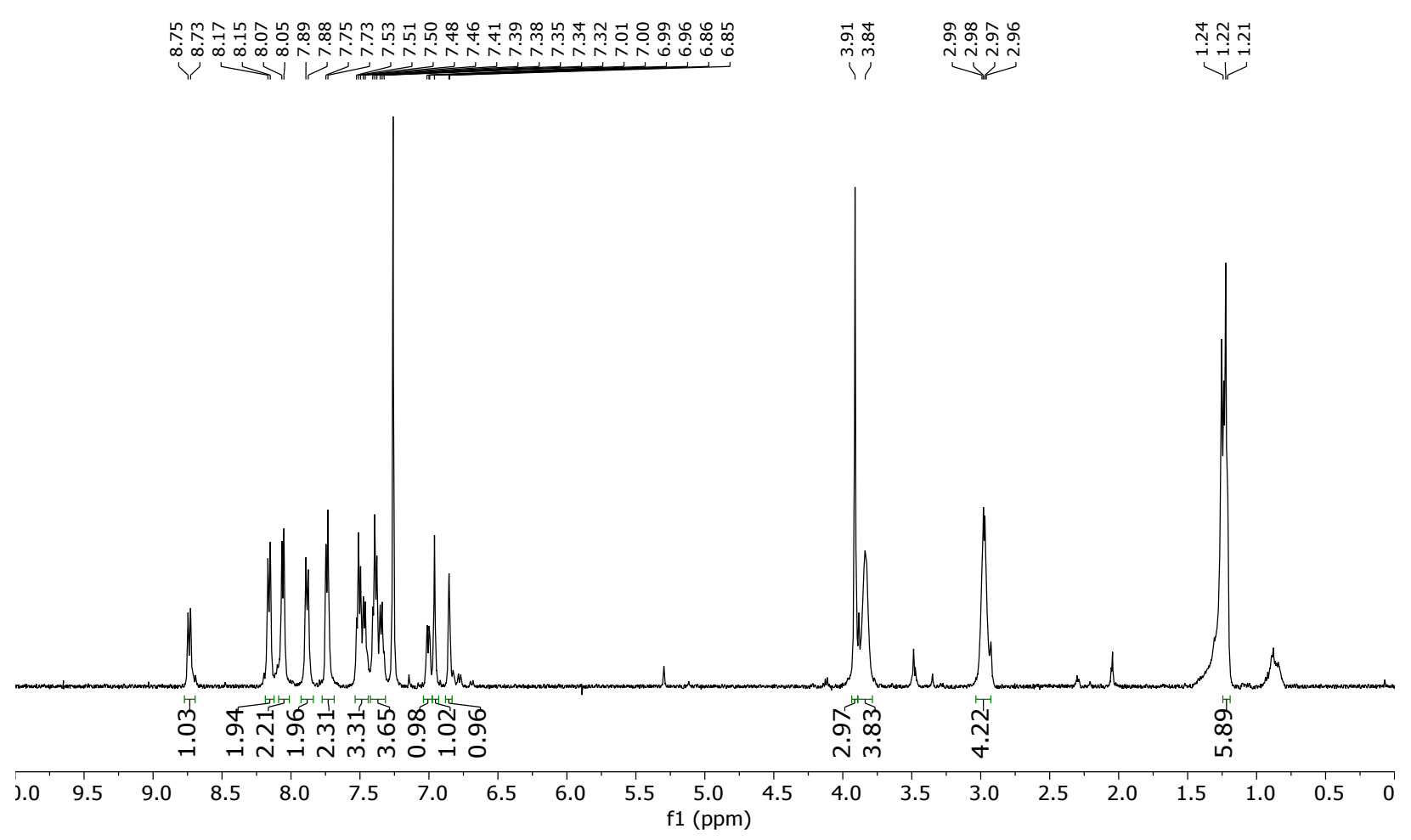

Figure S35. ${ }^{1} \mathrm{H}$ NMR of CRaB-HyP $\left(\mathrm{CDCl}_{3}\right)$.

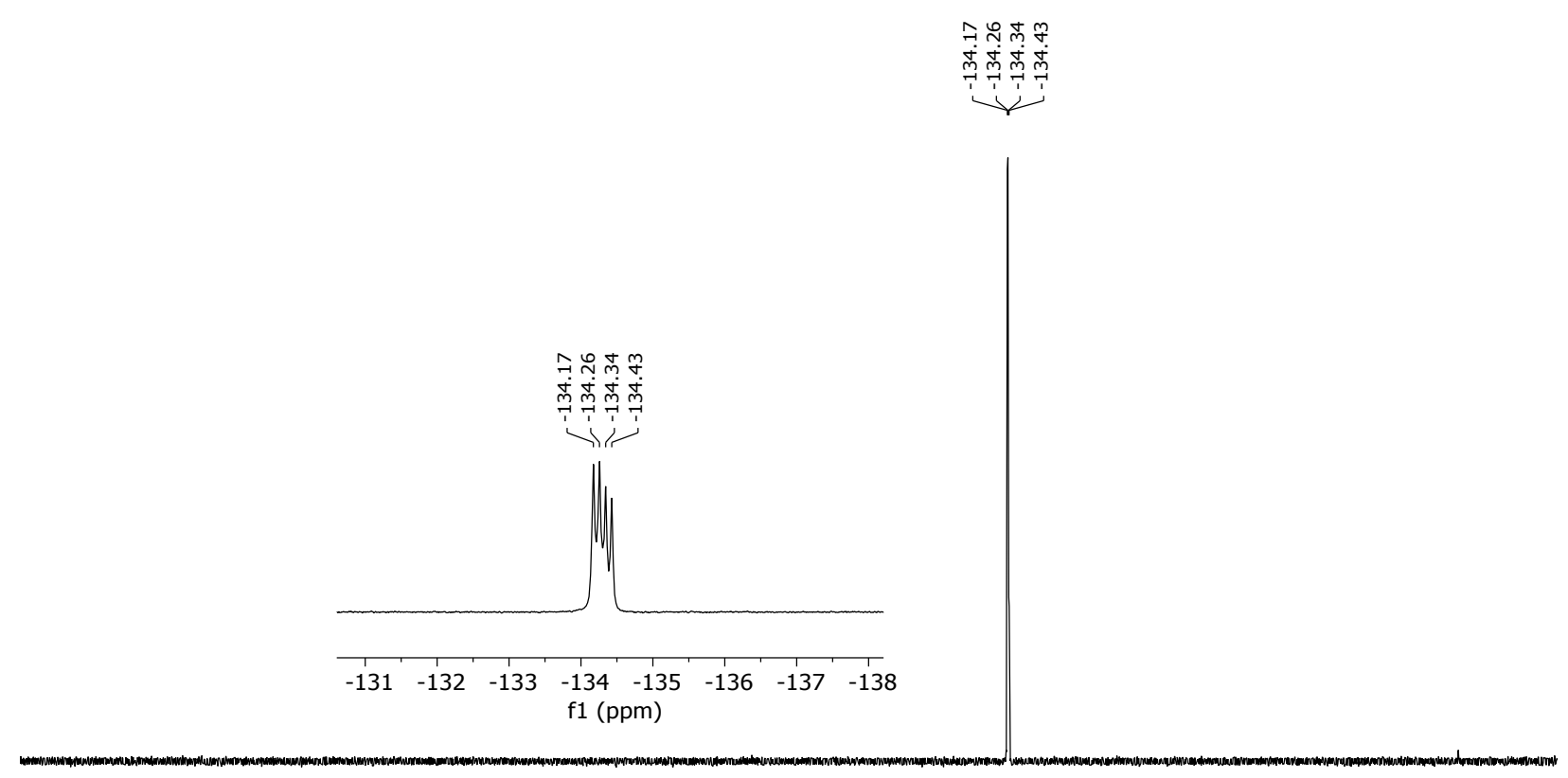

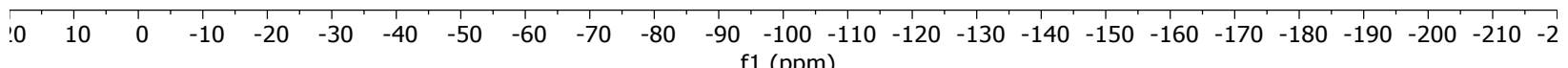

Figure S36. ${ }^{19} \mathrm{~F}$ NMR of CRaB-HyP $\left(\mathrm{CD}_{2} \mathrm{Cl}_{2}\right)$. 


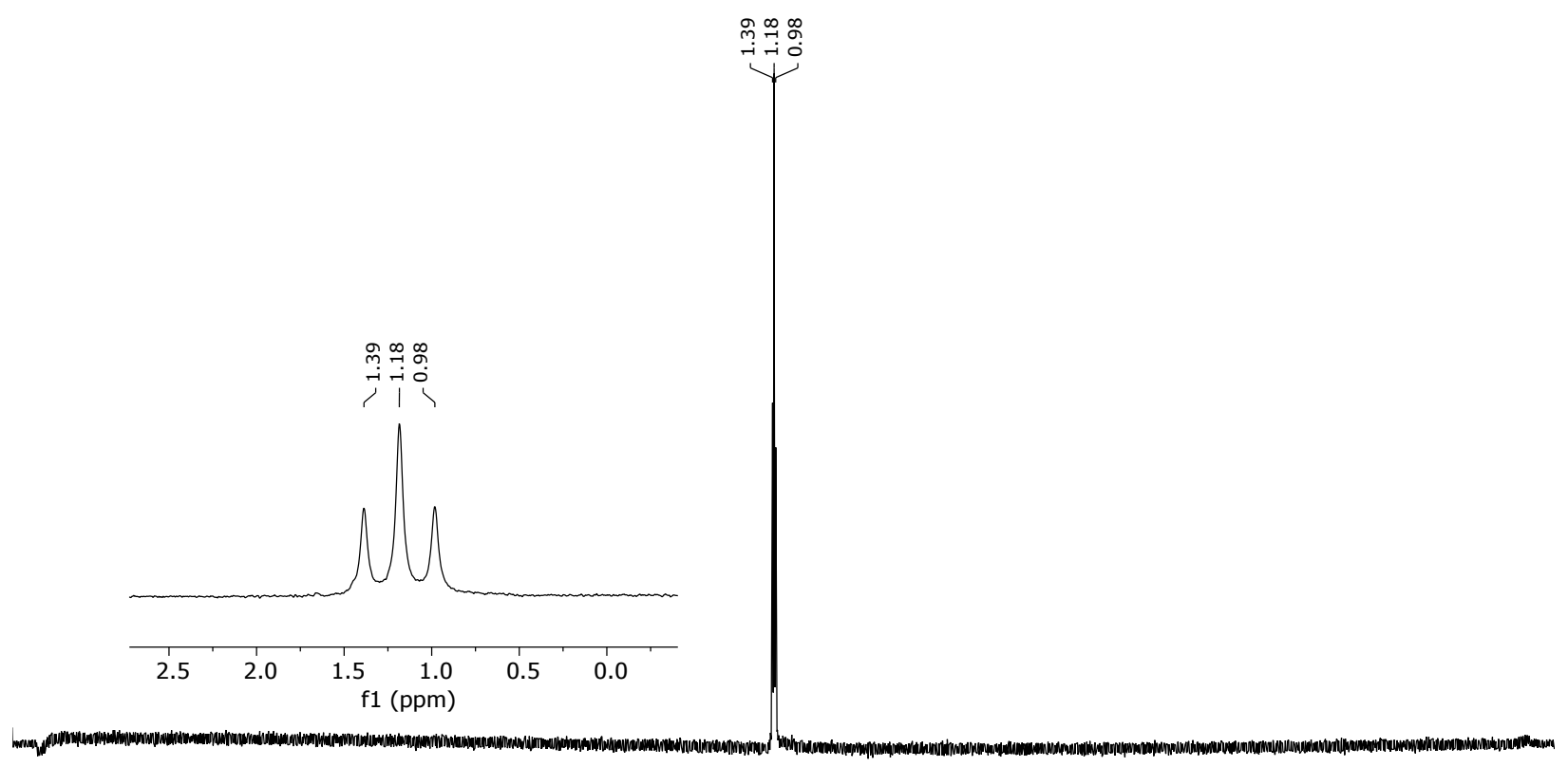

\begin{tabular}{llllllllllllllllllll}
\hline 90 & 80 & 70 & 60 & 50 & 40 & 30 & 20 & 10 & 0 & -10 & -20 & -30 & -40 & -50 & -60 & -70 & -80 & -90 & $f 1(\mathrm{ppm})$
\end{tabular}

Figure S37. ${ }^{11} \mathrm{~B}$ NMR of CRaB-HyP $\left(\mathrm{CD}_{2} \mathrm{Cl}_{2}\right)$.

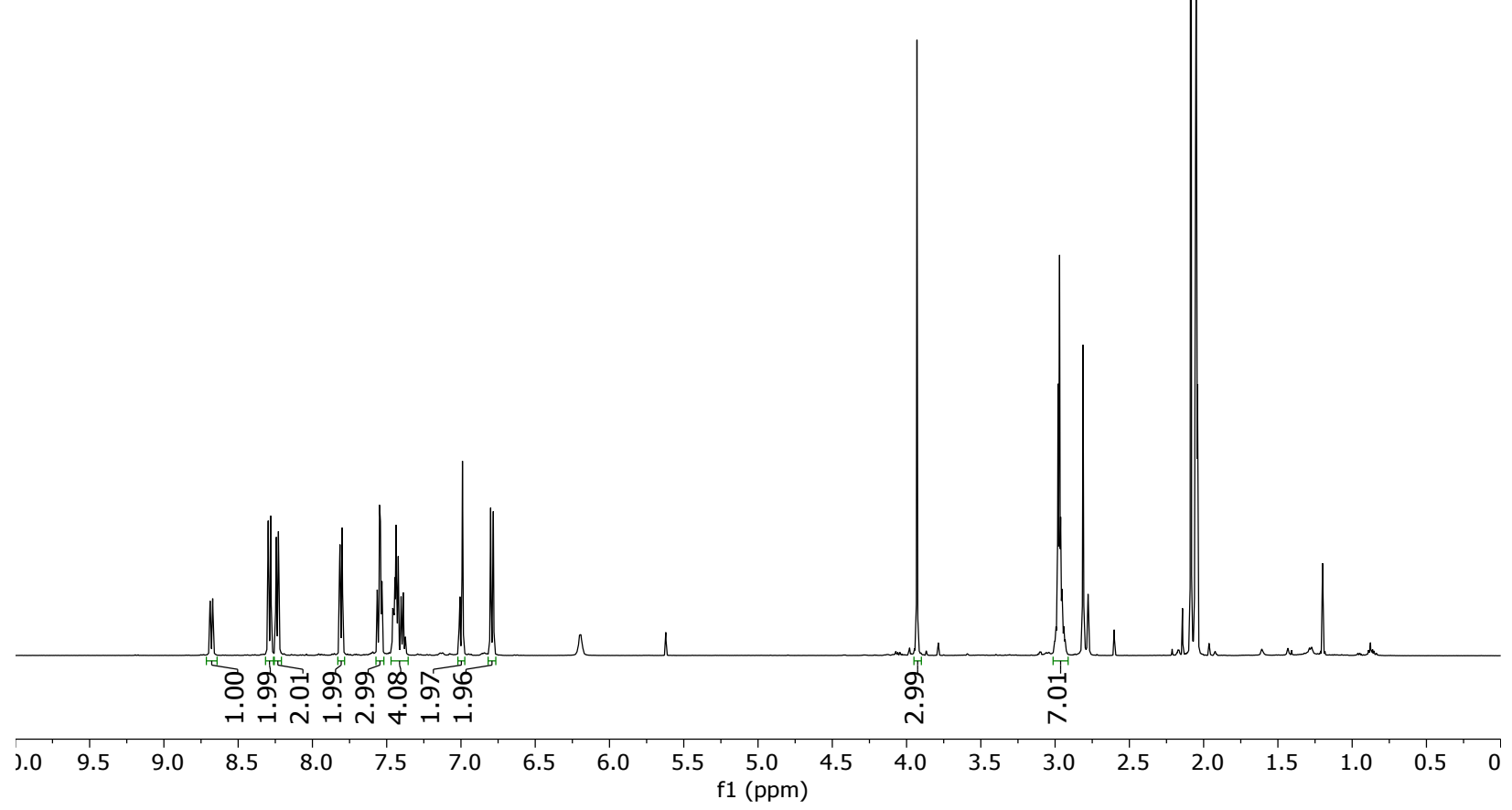

Figure S38. ${ }^{1} \mathrm{H}$ NMR of r-CRaB-NOD (Acetone- $\left.d_{6}\right)$. 


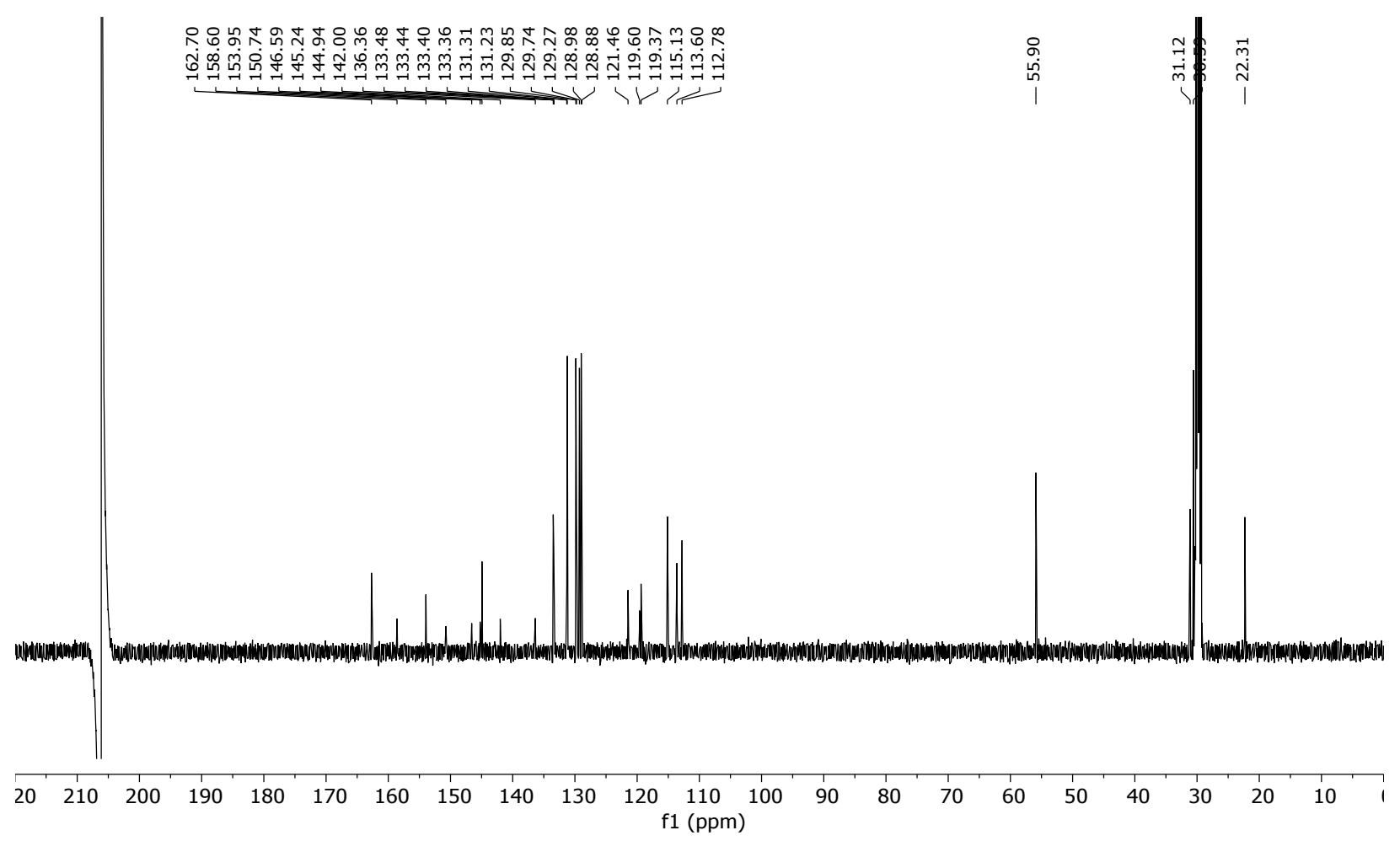

Figure S39. ${ }^{13} \mathrm{C}$ NMR of r-CRaB-NOD (Acetone- $d_{6}$ ).
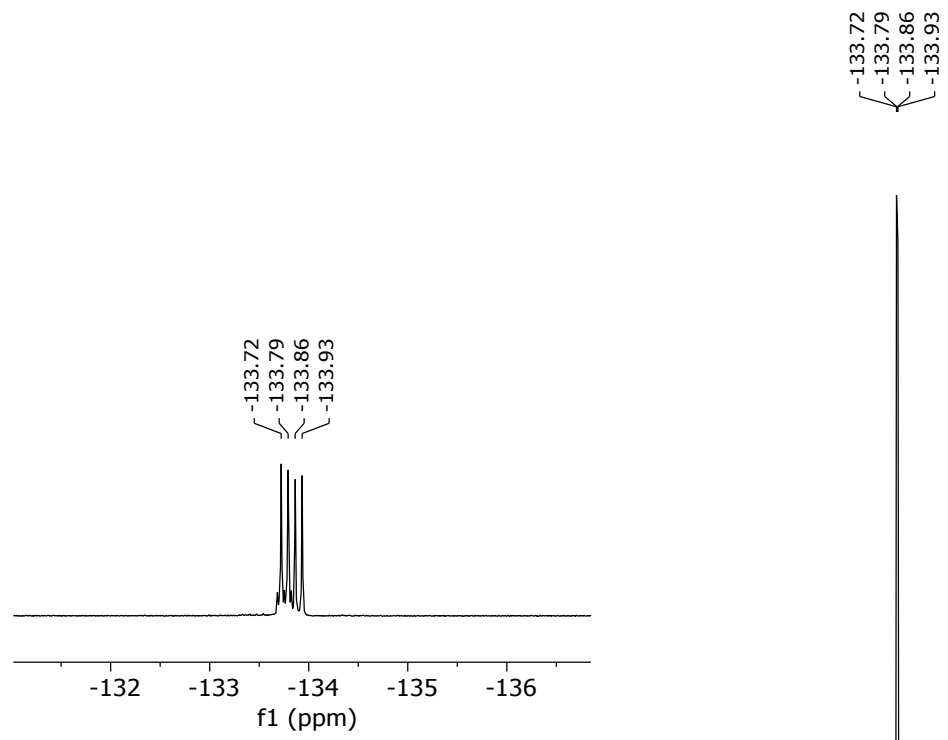

\begin{tabular}{llllllllllllllllllllllllllllllll}
\hline 0 & 10 & 0 & -10 & -20 & -30 & -40 & -50 & -60 & -70 & -80 & -90 & -100 & -110 & -120 & -130 & -140 & -150 & -160 & -170 & -180 & -190 & -200 & -210 & -2
\end{tabular} $\mathrm{f} 1(\mathrm{ppm})$

Figure S40. ${ }^{19} \mathrm{~F}$ NMR of r-CRaB-NOD (Acetone- $d_{6}$ ). 


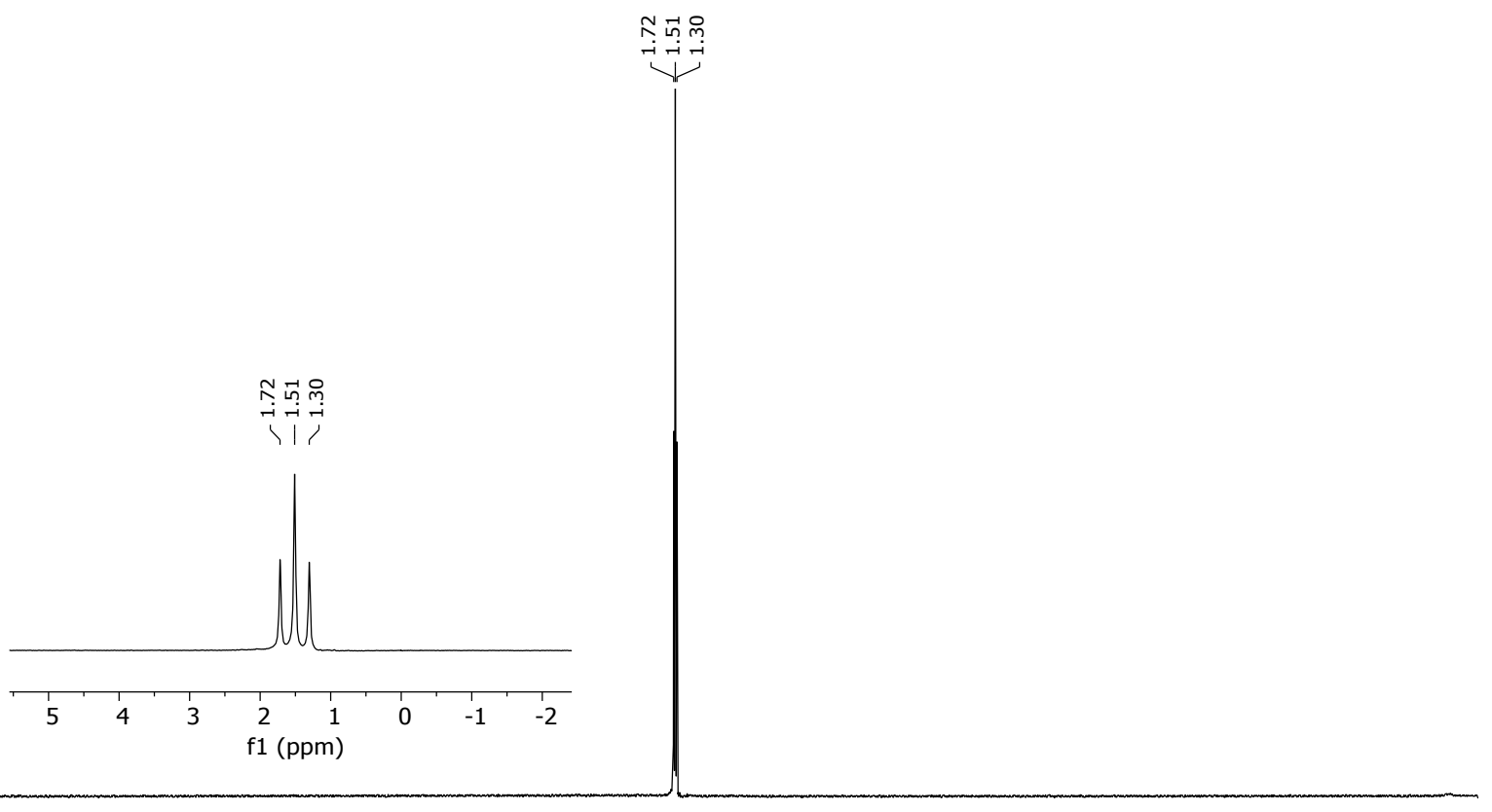

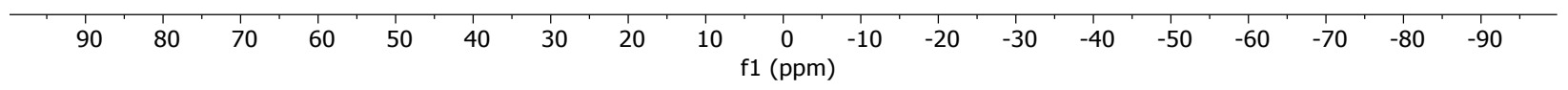

Figure S41. ${ }^{11}$ B NMR of r-CRaB-NOD (Acetone- $\left.d_{6}\right)$.

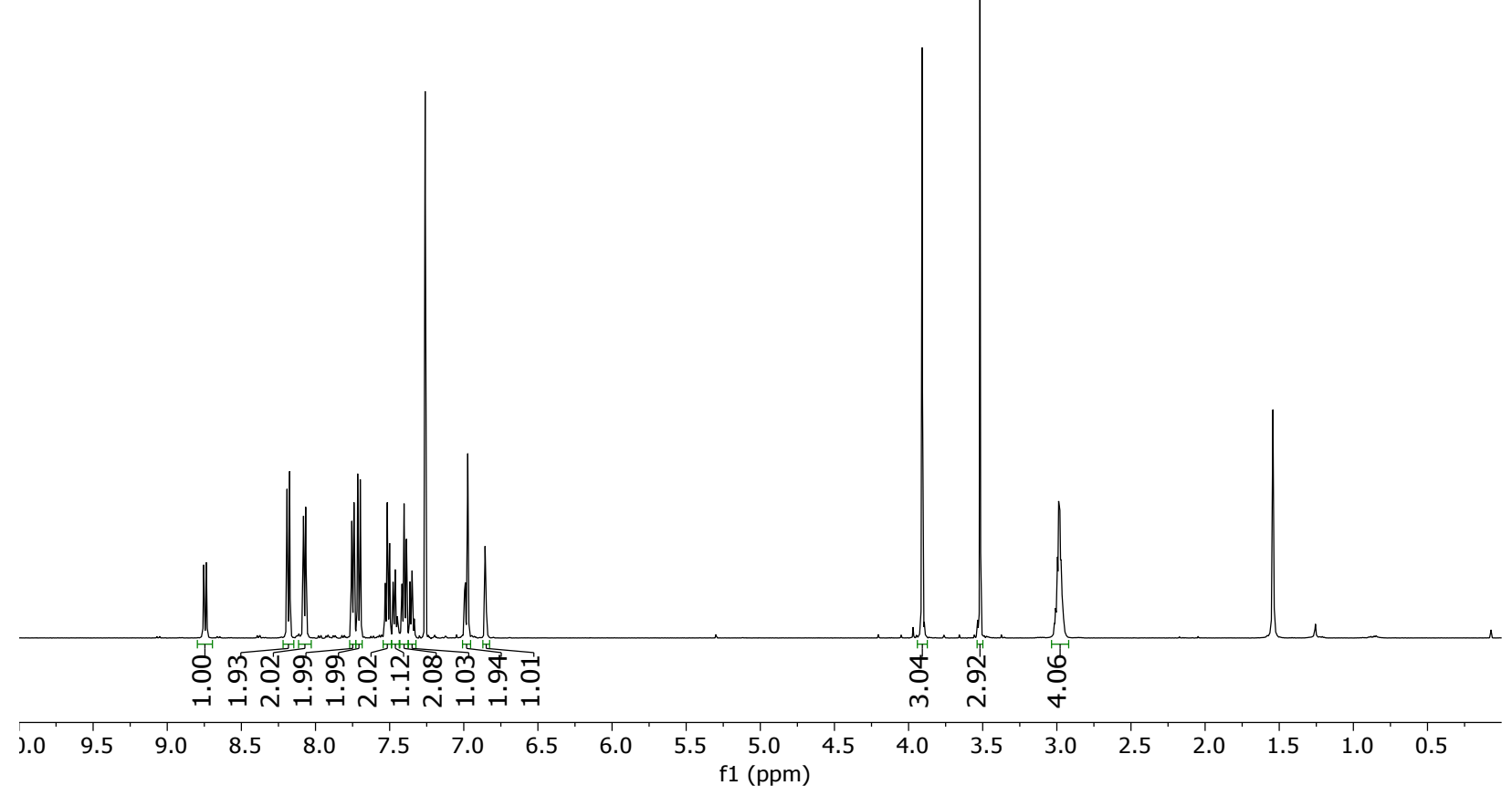

Figure S42. ${ }^{1} \mathrm{H}$ NMR of CRaB-photoNOD $\left(\mathrm{CDCl}_{3}\right)$. 


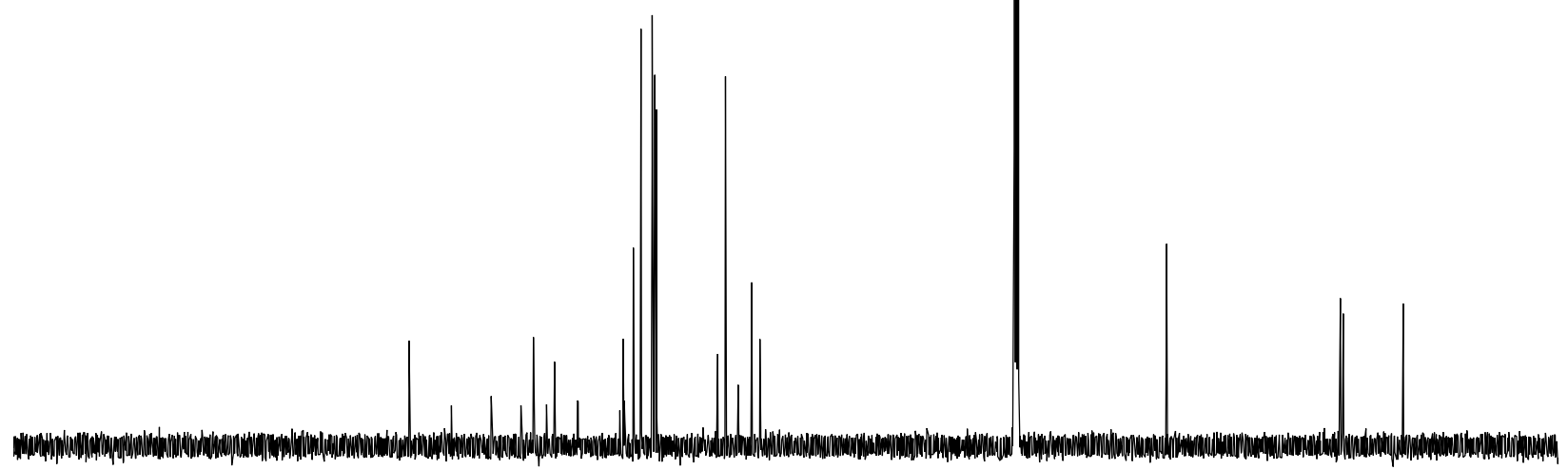

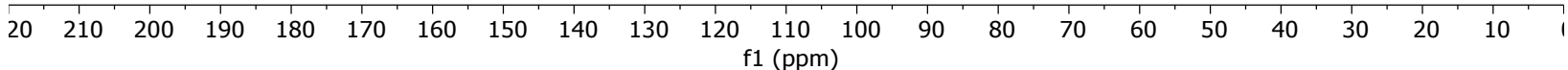

Figure S43. ${ }^{13} \mathrm{C}$ NMR of CRaB-photoNOD $\left(\mathrm{CDCl}_{3}\right)$.

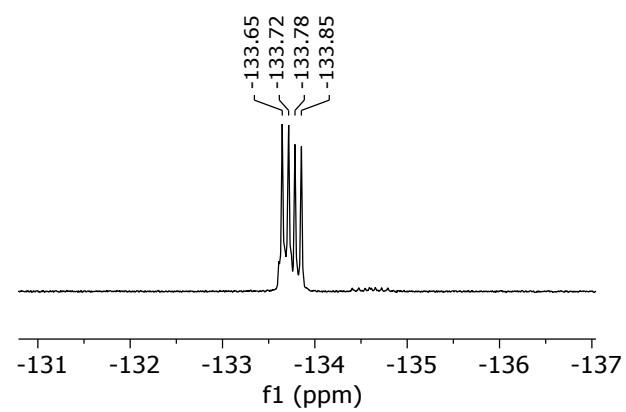

$\begin{array}{rlllllllllllllllllllllllll}20 & 10 & 0 & -10 & -20 & -30 & -40 & -50 & -60 & -70 & -80 & -90 & -100 & -110 & -120 & -130 & -140 & -150 & -160 & -170 & -180 & -190 & -200 & -210 & -2\end{array}$

Figure S44. ${ }^{19} \mathrm{~F}$ NMR of CRaB-photoNOD $\left(\mathrm{CDCl}_{3}\right)$. 

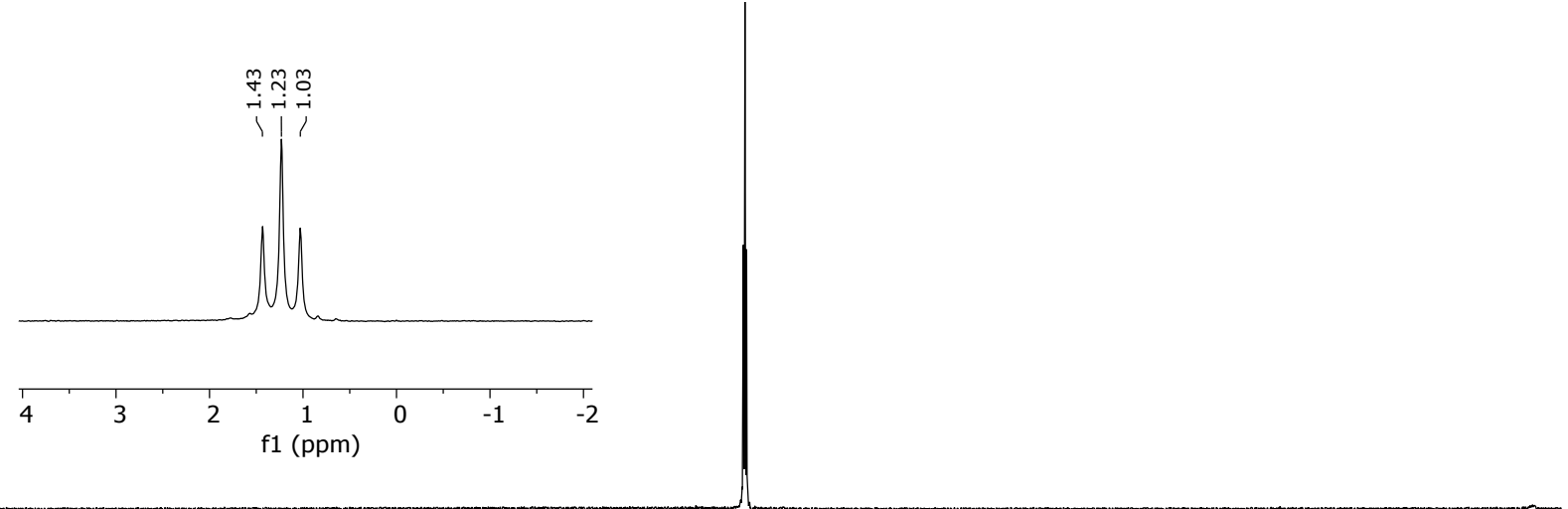

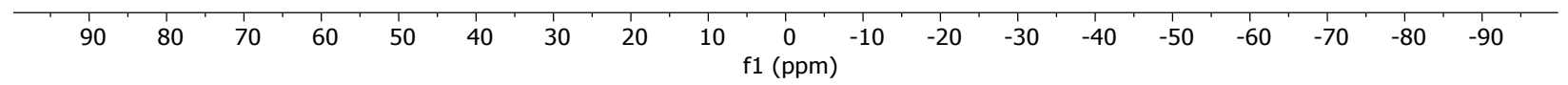

Figure S45. ${ }^{11} \mathrm{~B}$ NMR of CRaB-photoNOD $\left(\mathrm{CDCl}_{3}\right)$.

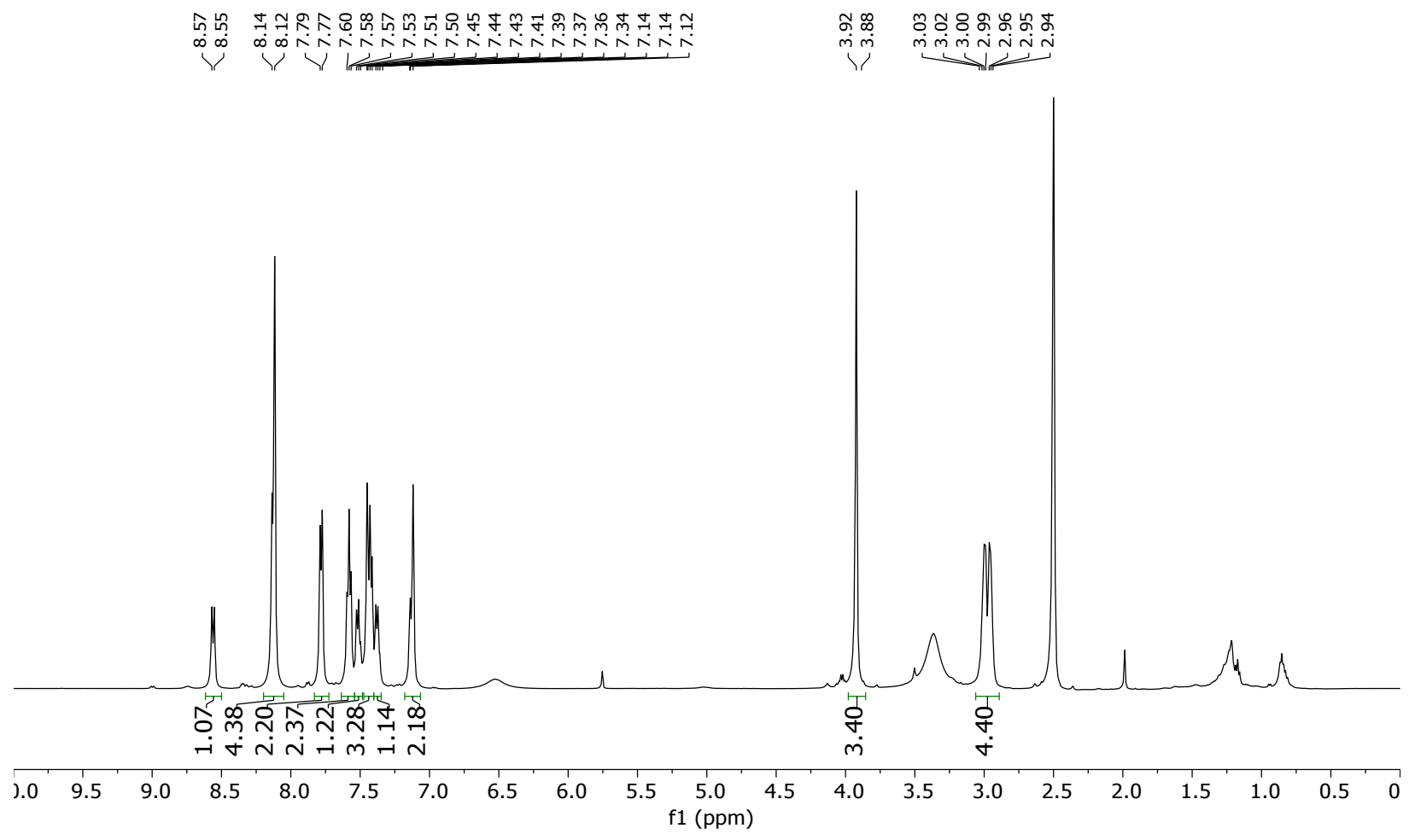

Figure S46. ${ }^{1} \mathrm{H}$ NMR of t-CRaB-OMe-APC (DMSO- $\left.d_{6}\right)$. 


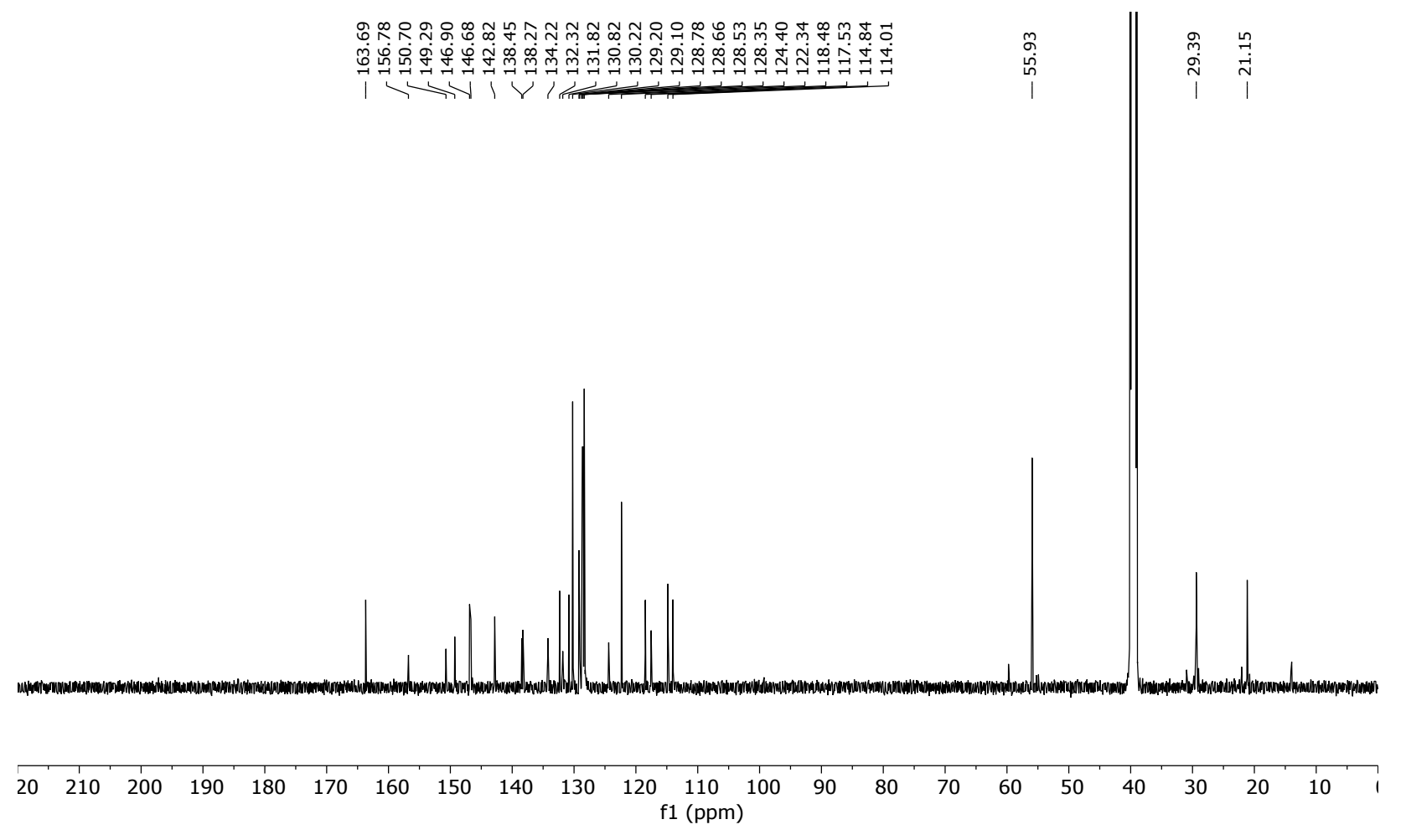

Figure S47. ${ }^{13} \mathrm{C}$ NMR of t-CRaB-OMe-APC (DMSO- $d_{6}$ ).

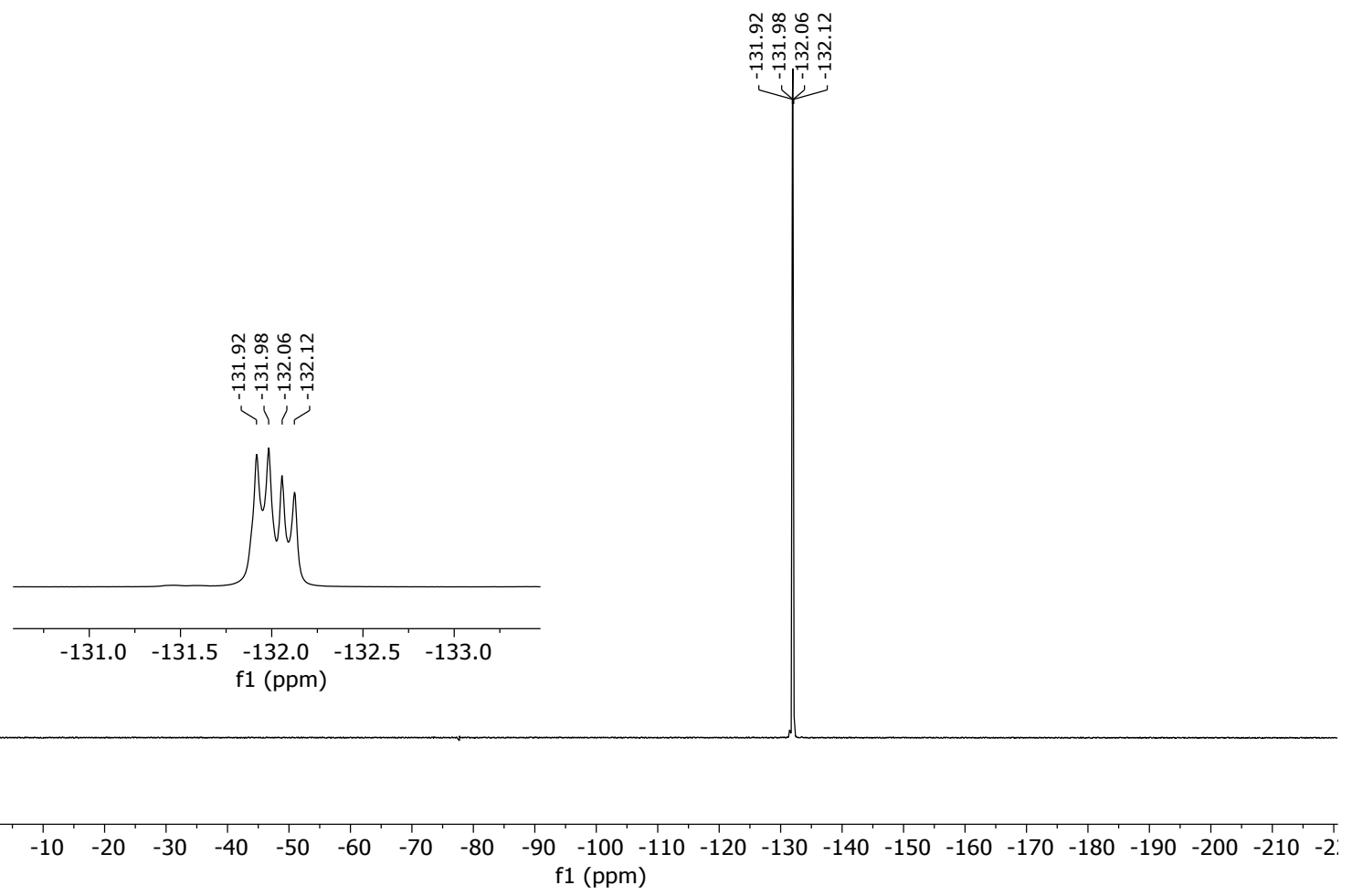

Figure S48. ${ }^{19} \mathrm{~F}$ NMR of t-CRaB-OMe-APC (DMSO- $\left.d_{6}\right)$. 


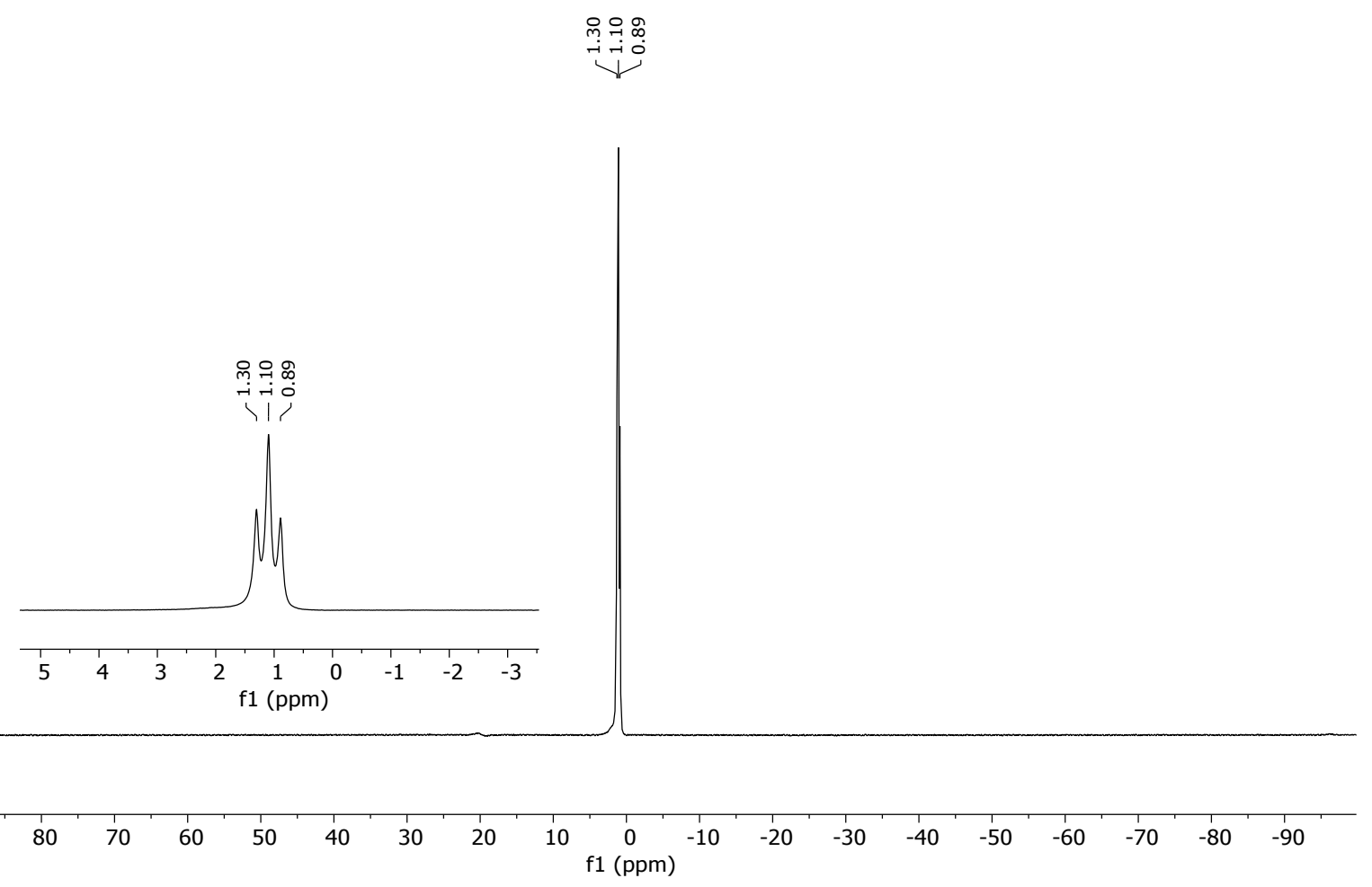

Figure S49. ${ }^{11} \mathrm{~B}$ NMR of t-CRaB-OMe-APC $\left(\right.$ DMSO- $\left.d_{6}\right)$.

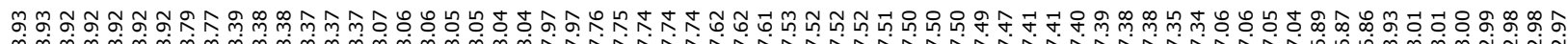

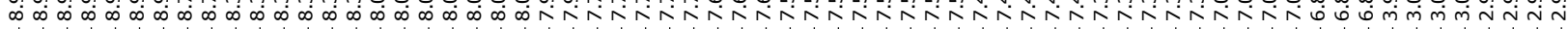

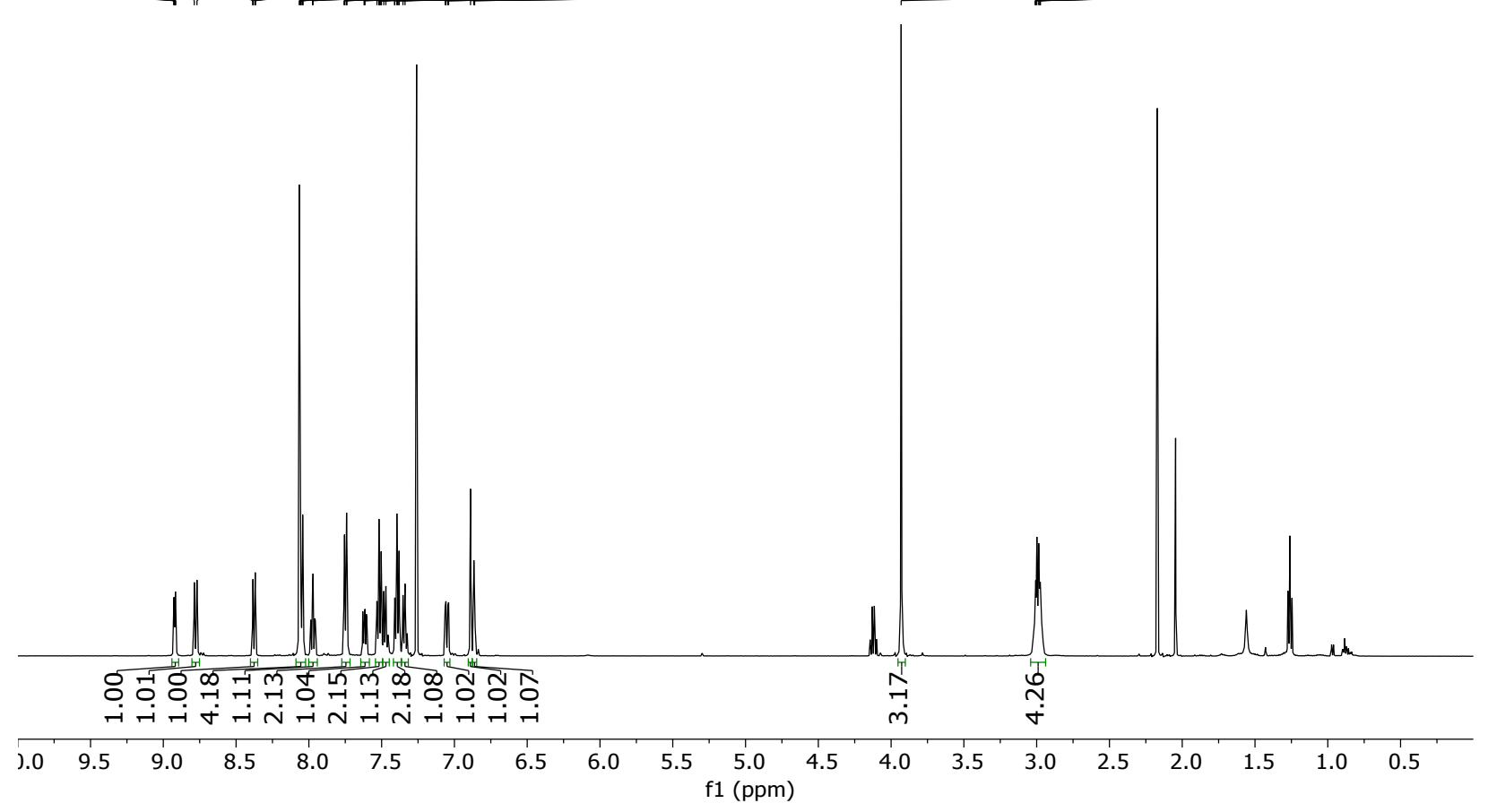

Figure S50. ${ }^{1} \mathrm{H}$ NMR of CRaB-OMe-APC $\left(\mathrm{CDCl}_{3}\right)$. 


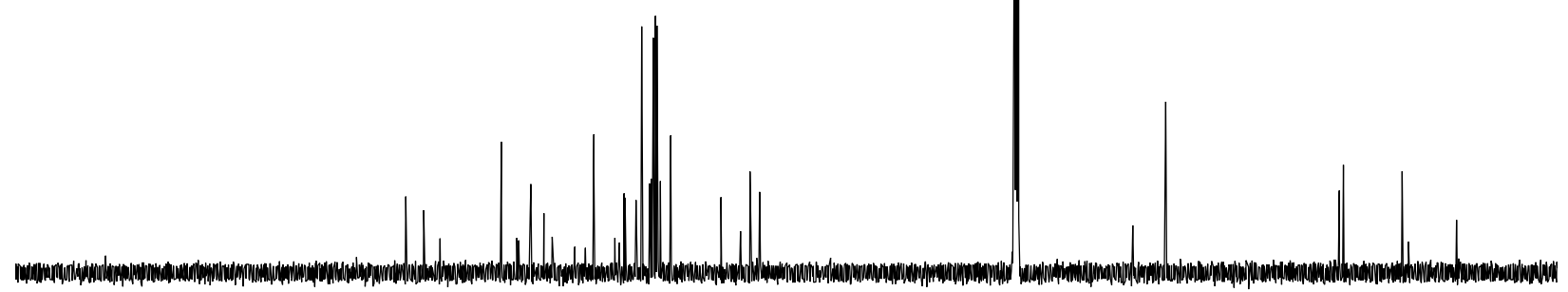

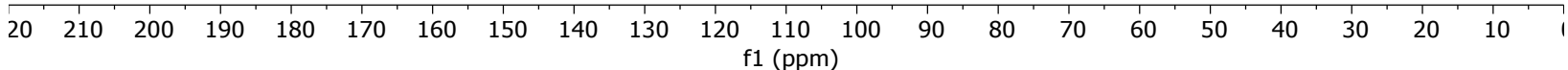

Figure S51. ${ }^{13} \mathrm{C}$ NMR of CRaB-OMe-APC $\left(\mathrm{CDCl}_{3}\right)$.

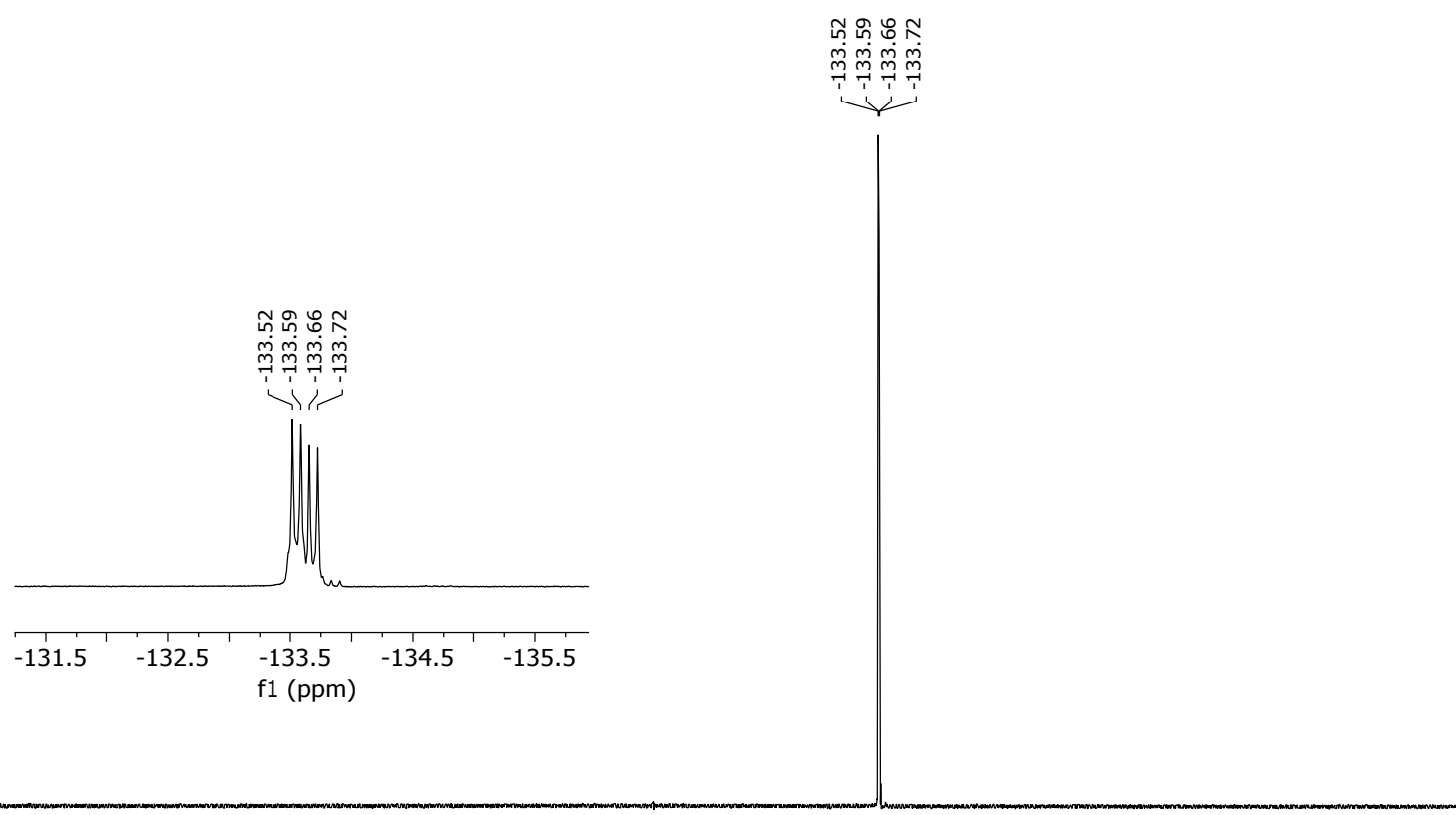

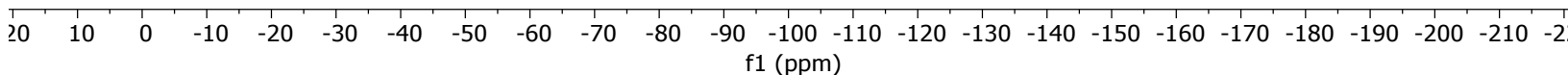

Figure S52. ${ }^{19} \mathrm{~F}$ NMR of CRaB-OMe-APC $\left(\mathrm{CDCl}_{3}\right)$. 


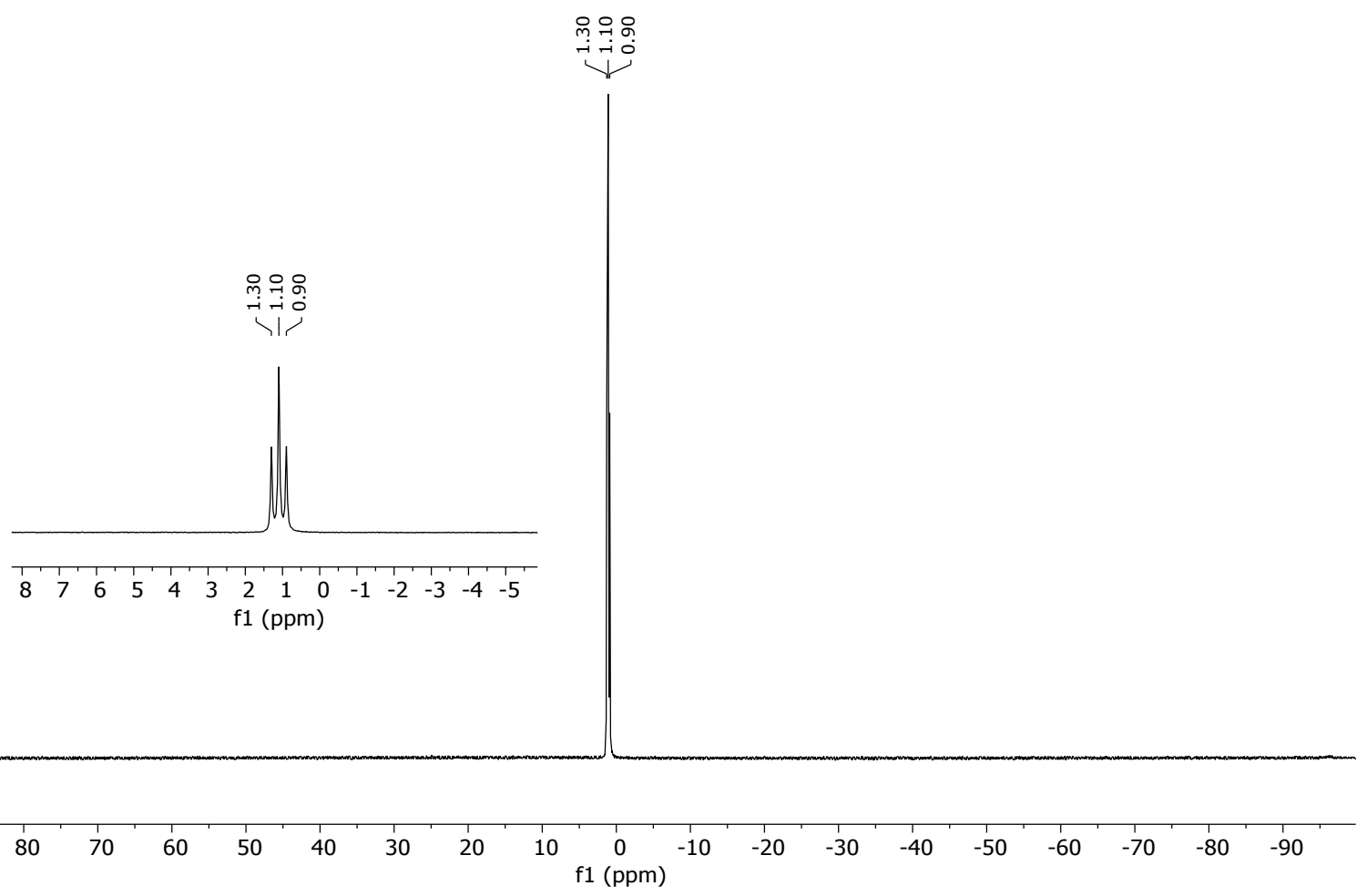

Figure S53. ${ }^{11} \mathrm{~B}$ NMR of CRaB-OMe-APC $\left(\mathrm{CDCl}_{3}\right)$.

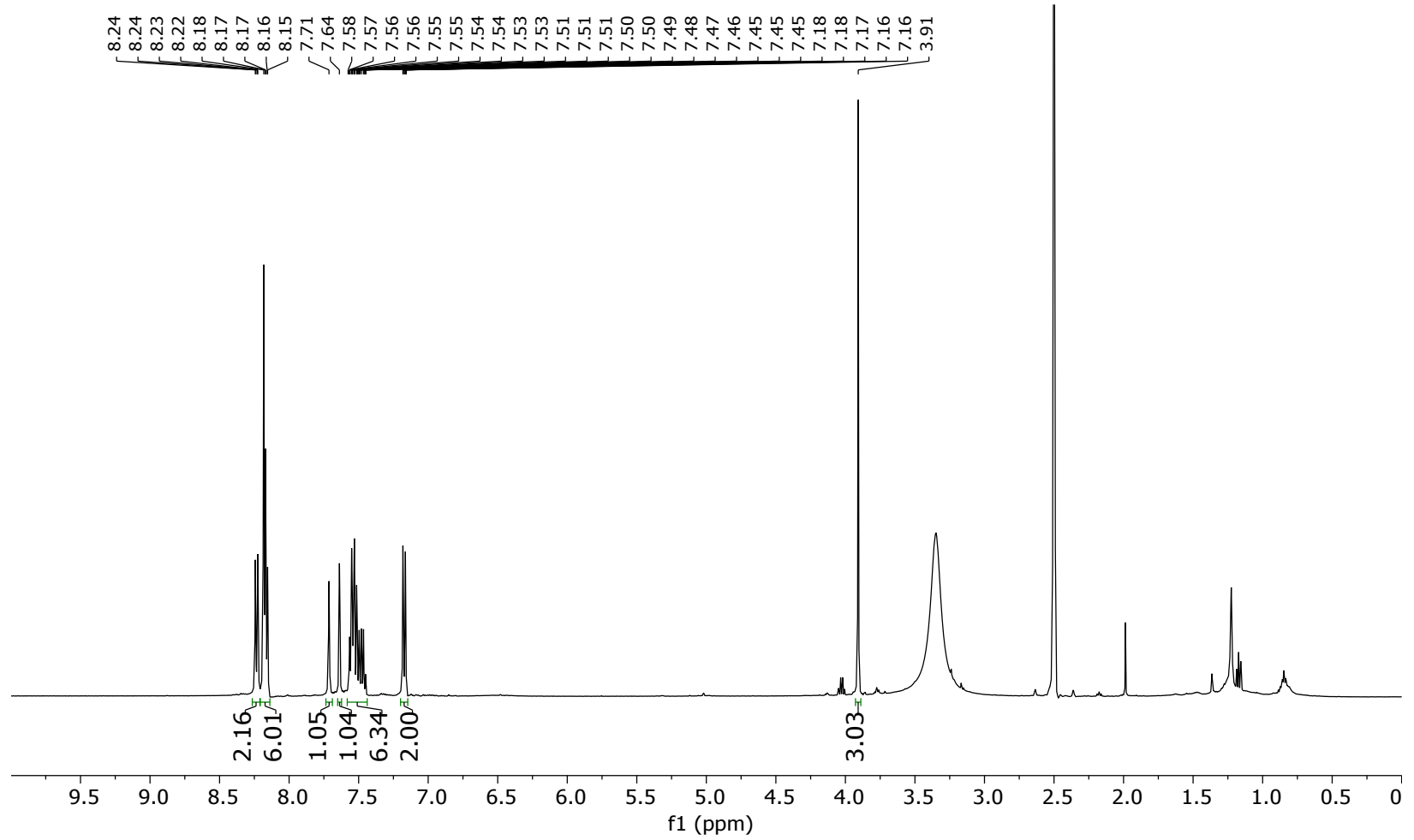

Figure S54. ${ }^{1} \mathrm{H}$ NMR of t-OMe-APC (DMSO- $\left.d_{6}\right)$. 

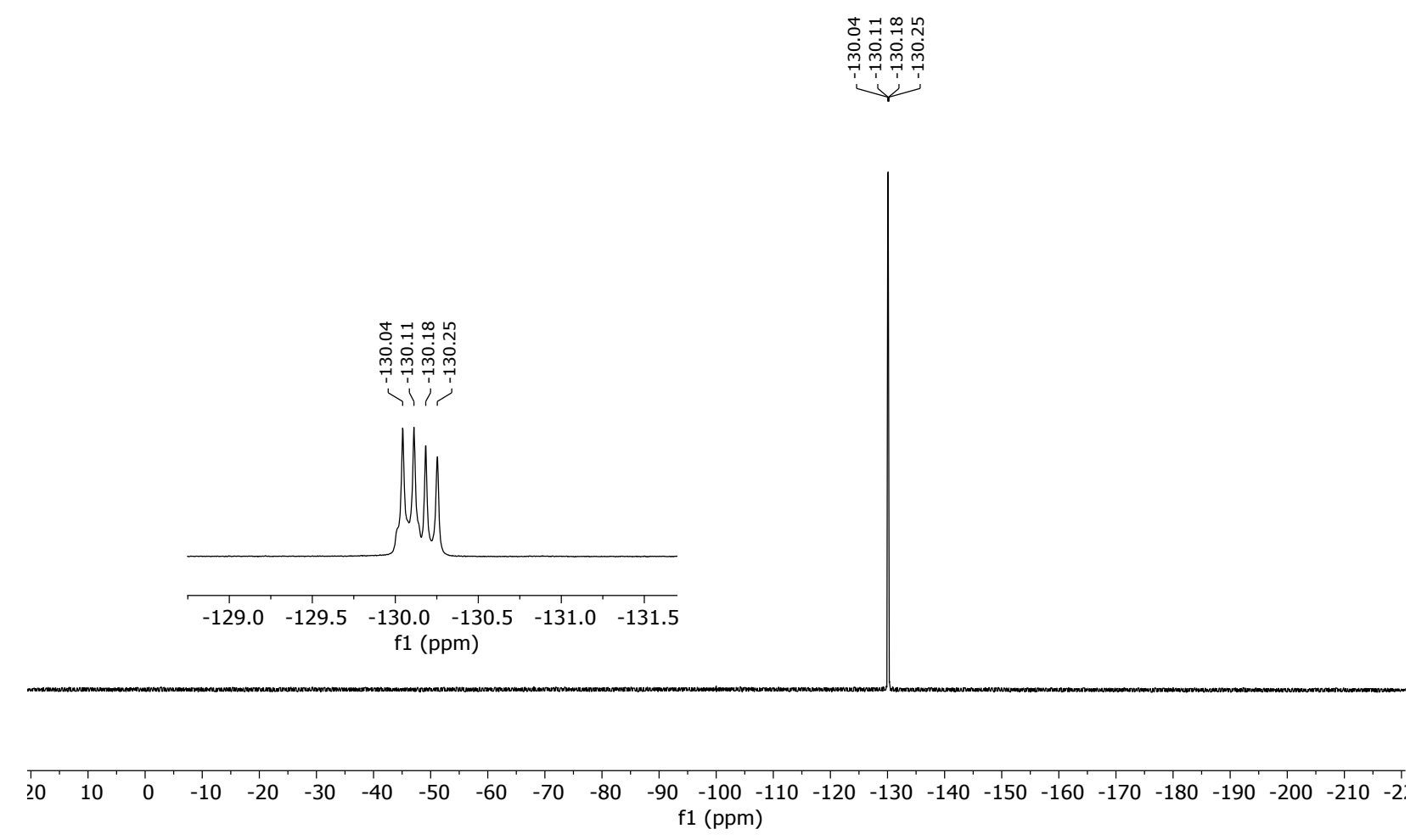

Figure S55. ${ }^{19} \mathrm{~F}$ NMR of t-OMe-APC (DMSO- $\left.d_{6}\right)$.

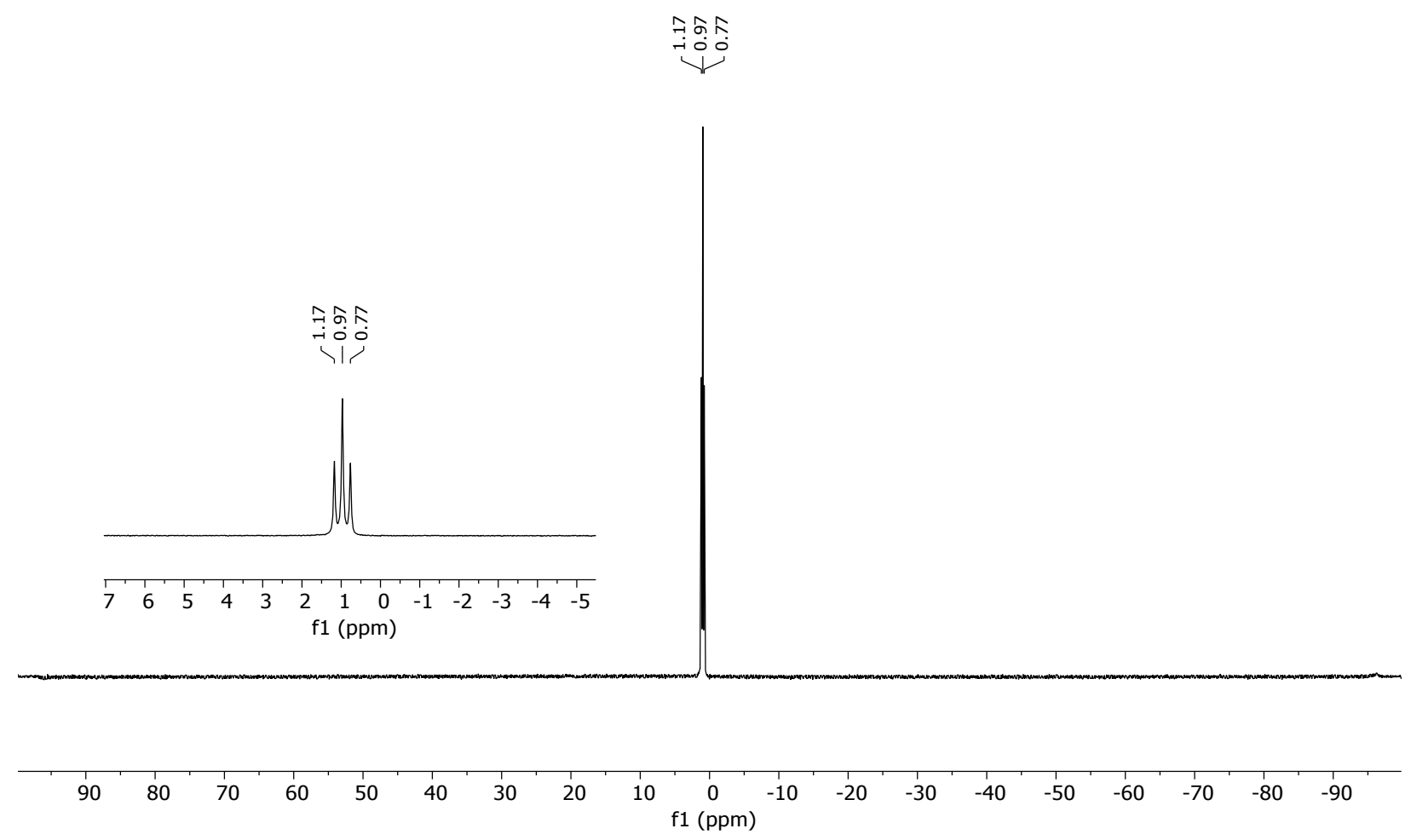

Figure S56. ${ }^{11} \mathrm{~B}$ NMR of t-OMe-APC (DMSO- $\left.d_{6}\right)$. 


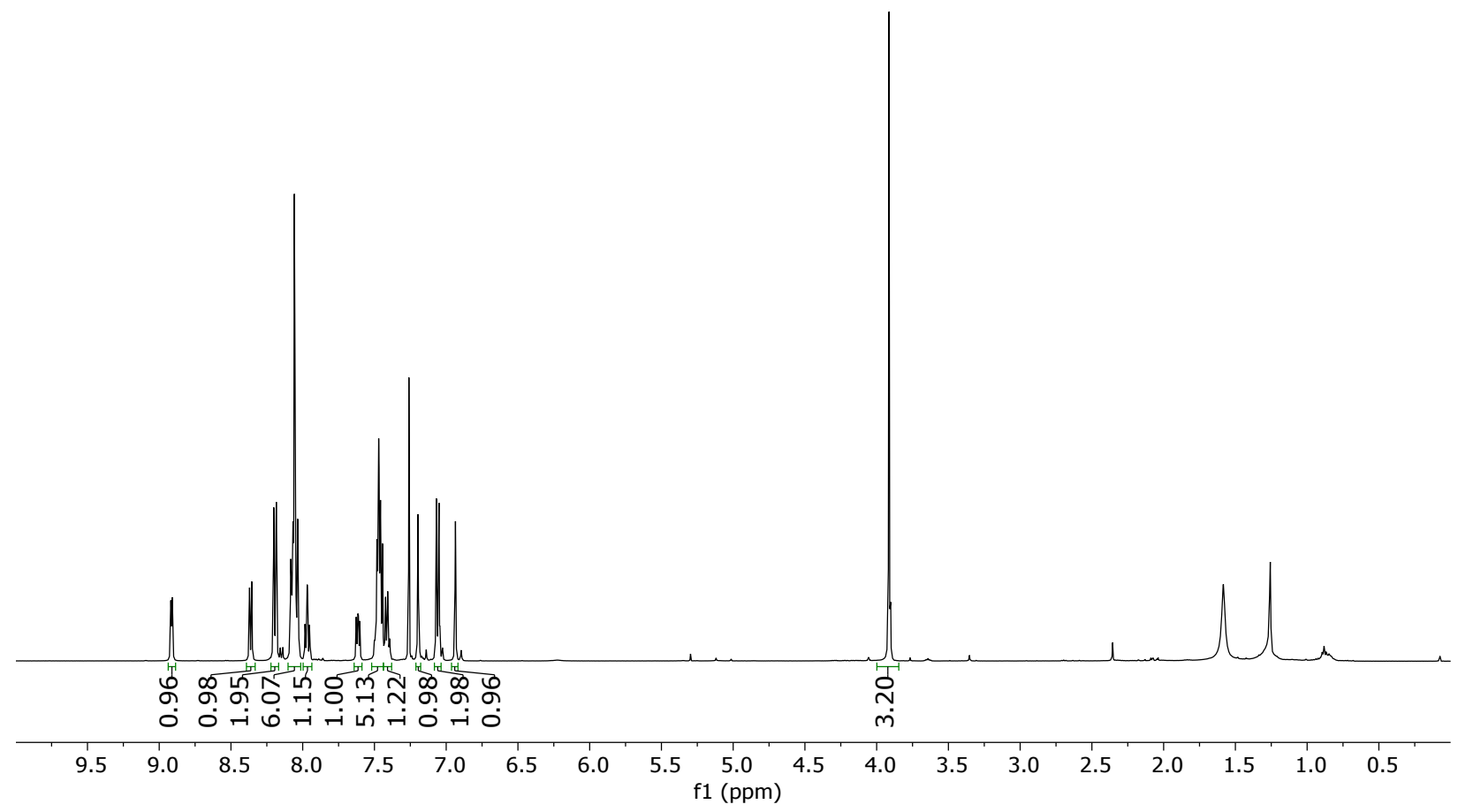

Figure S57. ${ }^{1} \mathrm{H}$ NMR of OMe-APC $\left(\mathrm{CDCl}_{3}\right)$.

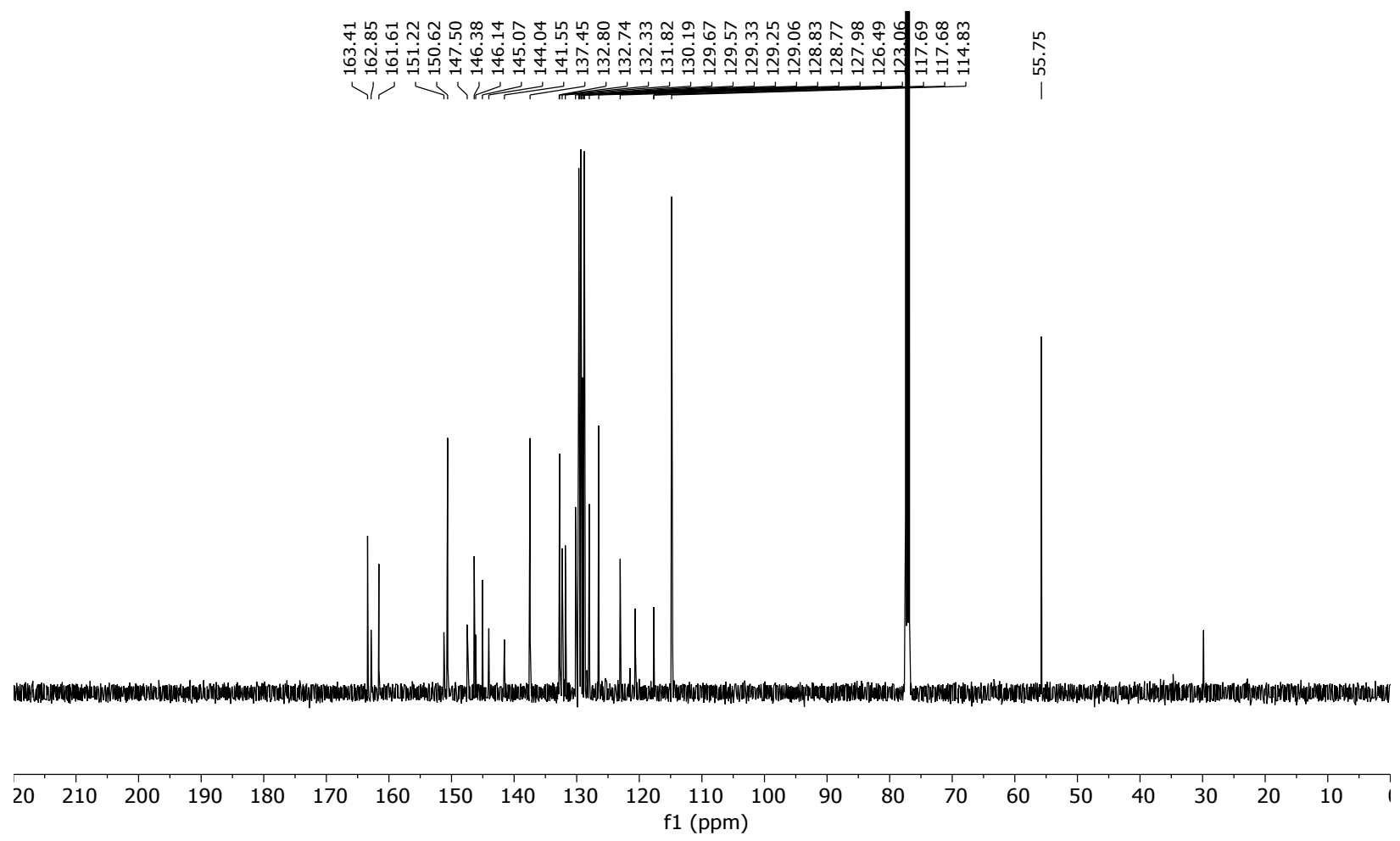

Figure S58. ${ }^{13} \mathrm{C}$ NMR of OMe-APC $\left(\mathrm{CDCl}_{3}\right)$. 


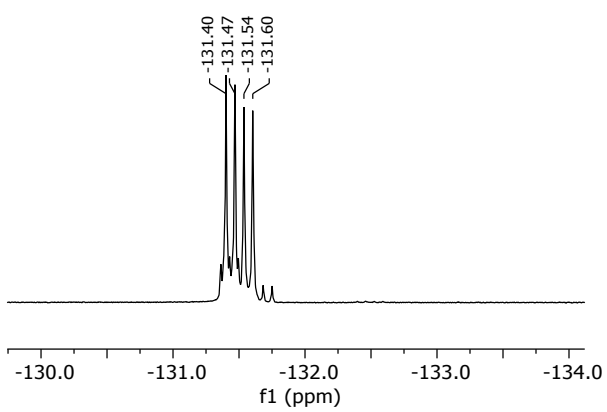

\begin{tabular}{llllllllllllllllllllllllll}
\hline 0 & 10 & 0 & -10 & -20 & -30 & -40 & -50 & -60 & -70 & -80 & -90 & -100 & -110 & -120 & -130 & -140 & -150 & -160 & -170 & -180 & -190 & -200 & -210 & -2
\end{tabular}

Figure S59. ${ }^{19} \mathrm{~F}$ NMR of OMe-APC $\left(\mathrm{CDCl}_{3}\right)$.

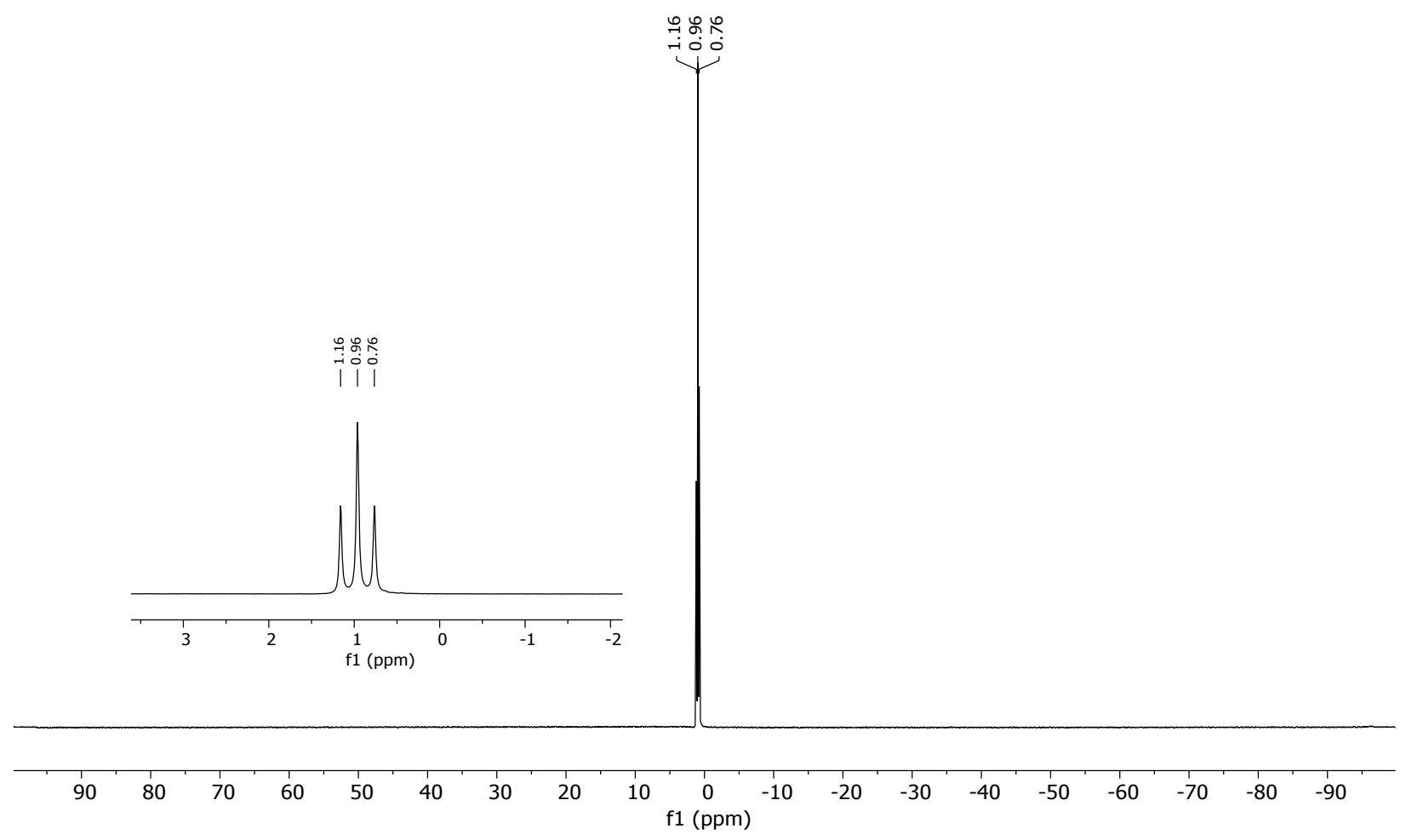

Figure S60. ${ }^{11} \mathrm{~B}$ NMR of OMe-APC $\left(\mathrm{CDCl}_{3}\right)$. 